\title{
What Can Economists Learn from Happiness Research?
}

\author{
Bruno S. Frey and Alois STUTZER ${ }^{1}$
}

\section{Why Study Happiness?}

$\mathrm{H}$ APPINESS IS generally considered an ultimate goal of life; virtually everybody wants to be happy. The United States Declaration of Independence of 1776 takes it as a self-evident truth that the "pursuit of happiness" is an "unalienable right," comparable to life and liberty. It follows that economics is-or should be-about individual happiness; in particular, how do economic growth, unemployment and inflation, and institutional factors such as governance affect individual well-being?

In addition to this intrinsic interest, there are important reasons for economists to consider happiness research. The first is economic policy. At the microlevel, it is often impossible to make a Pareto-improving proposal, because a social action entails costs for some individuals. Hence an evaluation of the net effects, in terms of individual utilities, is needed. On an aggregate level, economic policy must deal with trade-offs, especially those between unemployment and inflation. Data for twelve European countries for the period 1975-91 show that a 1-percentage-point increase in the unemployment rate is

\footnotetext{
${ }^{1}$ University of Zurich, Institute for Empirical Research in Economics. We wish to thank a large number of scholars and three referees for their detailed comments on this and previous versions of the paper.
}

marginally compensated for by a 1.7percentage-point decrease in inflation (Rafael Di Tella, Robert MacCulloch, and Andrew Oswald 2001). This result significantly deviates from the "misery index" that, for lack of information, has simply been defined as the sum of the percent unemployment rate and the percent annual inflation rate. Another trade-off that can be calculated on the basis of estimated happiness functions is the compensating variation for being unemployed rather than holding a job. For the same European countries referred to above, a move from the lowest income quartile to the highest income quartile would not be enough to offset the adverse effect of unemployment, suggesting that unemployed people suffer high non-pecuniary costs. Happiness research can thus usefully inform economic policy decisions.

Another reason why happiness is of relevance to economists is the effect of institutional conditions such as the quality of governance and the size of social capital on individual well-being. Research for 49 countries in the 1980s and 1990s suggests that there are substantial well-being benefits from factors such as improved accountability, effectiveness and stability of government, the rule of law, and control of corruption. The data show that the effects flowing directly from the quality of 
institutions are often much larger than those that flow through productivity and economic growth (John Helliwell 2001).

Happiness research can also help us understand the formation of subjective well-being. This sheds new light on basic concepts and assumptions of economic theory, such as whether people can successfully predict their own future utilities (George Loewenstein, Ted O'Donoghue, and Matthew Rabin 2000) or whether individual self-assessments of predicted, instant, and remembered utility are consistent (Daniel Kahneman, Peter Wakker, and Rakesh Sarin 1997). It may also help to solve empirical puzzles that conventional economic theories find difficult to explain. A paradox needing explanation, for example, is that in several countries since World War II real income has drastically risen but self-reported subjective well-being ${ }^{2}$ of the population has not increased or has even fallen slightly. In the United States between 1946 and 1991, per-capita real income rose by a factor of 2.5 (from approximately $\$ 11,000$ to $\$ 27,000$ in 1996 US $\$$ ), but over the same period, happiness on average remained constant. ${ }^{3}$ At a given point in time, higher income is positively associated with people's happiness, yet over the life cycle, happiness stays more or less unchanged. Another paradox is that, since ancient times, work has been considered a burden for individuals to bear, but empirical research on happiness strongly suggests that being un-

\footnotetext{
${ }^{2}$ Subjective well-being is the scientific term in psychology for an individual's evaluation of her experienced positive and negative affect, happiness, or satisfaction with life. They are separable constructs, and the precise terminology will be used whenever empirical research is cited. Otherwise, the terms happiness, well-being, and life satisfaction are used interchangeably.

${ }^{3}$ This is a "well-established finding" (Richard Easterlin 2001, p. 472, 1974, 1995; David Blanchflower and Oswald 2000; Ed Diener and Shigehiro Oishi 2000; and Charles Kenny 1999).
}

employed, even when receiving the same income as when employed, depresses people's well-being markedly. ${ }^{4}$

Many happiness research findings add new knowledge to what have become standard views in economics, while other results challenge those views. One finding is the consistently large influence of nonfinancial variables on self-reported satisfaction. This does not mean that economic factors such as income, employment, and price stability are unimportant, but does suggest that the recent interest in issues such as good governance and social capital is wellfounded. The findings also enrich our knowledge of discrimination concerning gender, ethnicity and race, and age.

Section 2 discusses the relationship between happiness and utility, and argues that reported subjective wellbeing is a satisfactory empirical approximation of individual utility. Sections 3 to 5 report on how the economic variables of income, unemployment, and inflation affect happiness. Section 6 shows that, in addition to current economic conditions, institutional factors, in particular the type of democracy and the extent of government decentralization, systematically influence how satisfied individuals are with their lives. Section 7 provides a summary and discusses the implications for economic policy and theory.

\section{Happiness and Utility}

\subsection{Historical Sketch}

For a long time, the study of happiness was the province of psychology. ${ }^{5}$

\footnotetext{
${ }^{4}$ In addition to the literature already cited, see Blanchflower (1996), Andrew Clark and Oswald (1994), Frey and Stutzer (1999), and Liliana Winkelmann and Rainer Winkelmann (1998).

5 See, for example, Michael Argyle (1987), Diener et al. (1999), Kahneman, Diener, and Norbert Schwarz (1999), Alex Michalos (1991), David Myers (1993), Richard Ryan and Edward Deci (2001),
} 
Only recently has this psychological research been linked to economics. The pathbreaking contribution by Easterlin (1974) was noted by many economics scholars, but at the time found few followers. General interest in the measurement and determinants of subjective reported well-being was raised by a symposium (Robert Frank 1997; Yew-Kwang Ng 1997; and Oswald 1997). Since the late 1990s, economists have started to contribute large-scale empirical analyses of the determinants of happiness in different countries and periods.

This paper does not intend to provide a general survey on happiness research (which has already been done by Kahneman, Diener, and Schwarz 1999, and Frey and Stutzer 2002). Rather, we wish to show which insights may be important, if not necessary, for integrating into economics.

\subsection{Objective and Subjective Utility}

Standard economic theory employs an "objectivist" position based on observable choices made by individuals. Individual utility only depends on tangible goods and services and leisure. It is inferred from behavior (or revealed preferences), and is in turn used to explain the choices made. This "modern" view of utility has been influenced by the positivistic movement in philosophy. Subjectivist experience (e.g., captured by surveys) is rejected as being "unscientific," because it is not objectively observable. Most importantly, cardinality of utility and interpersonal comparability are not necessary for positive demand theory, which, following Occam's razor, constitutes a great

and Fritz Strack, Argyle, and Schwarz (1991). There are also contributions by sociologists, in particular Ruut Veenhoven (for example 1993), and political scientists (Ronald Inglehart 1990; Robert Lane 2000). advantage (Lionel Robbins 1932; John Hicks 1934; Roy Allen 1934). The axiomatic revealed-preference approach holds that the choices made provide all the information required to infer the utility of outcomes. The axiomatic approach is not only applied to derive individual utility, but also to measure social welfare. To do so, social welfare comparison is based on the consumption behavior of households (Daniel Slesnick 1998; for a critical analysis $\mathrm{Ng}$ 1997, 2001).

The positivistic view still dominates in economics. Amartya Sen (1986, p. 18) observes that "the popularity of this view in economics may be due to a mixture of an obsessive concern with observability and a peculiar belief that choice. . . is the only human aspect that can be observed." Its dominance is reflected in the contents of microeconomics textbooks. Not all contemporary economists, however, subscribe to this view. Numerous scholars have challenged standard economic theory from different angles. There are countless examples of nonobjectivist theoretical analyses in economics. They incorporate emotions (Jon Elster 1998) self-signaling (self-esteem), goal completion, mastery and meaning (Loewenstein 1999) or status (Frank 1985). In order to explain human behavior, interdependent utility functions are considered, rather than interpersonally independent ones (Clark and Oswald 1998). This challenges established welfare propositions (Michael Boskin and Eytan Sheshinski 1978; Heinz Holländer 2001; and Richard Layard 1980). The vast literature on anomalies in decision making (Richard Thaler 1992) questions whether utility can generally be derived from observed choices. Finally, consequentialism, of which utilitarianism is a special case, is not the only aspect relevant for behavior, for procedural utility should also be 
considered (Sen 1995, 1997; Marc Le Menestrel 2001). The exclusive reliance on an objectivist approach by standard economic theory is thus open to doubt, both theoretically and empirically. In any case, it restricts the possibility of understanding and influencing human well-being.

The subjective approach to utility offers a fruitful complementary path to study the world. Firstly, subjective well-being is a much broader concept than decision utility; it includes experienced utility as well as procedural utility, and is for many people an ultimate goal. That is not the case for other things we may want, such as job security, status, power, and especially money (income). We do not want them for themselves, but rather to give us the possibility of making ourselves happier. Secondly, the concept of subjective happiness allows us to capture human well-being directly. This creates a basis for explicitly testing fundamental assumptions and propositions in economic theory.

\subsection{Measuring Utility}

A subjective view of utility recognizes that everybody has their own ideas about happiness and the good life and that observed behavior is an incomplete indicator for individual well-being. Nevertheless, individuals' happiness can be captured and analyzed: people can be asked how satisfied they are with their lives. It is a sensible tradition in economics to rely on the judgement of the persons directly involved. People are reckoned to be the best judges of the overall quality of their lives, and it is a straightforward strategy to ask them about their well-being. With the help of one or more questions on global selfreports, it is possible to get indications of individuals' evaluations of their life satisfaction or happiness. Behind the score indicated by a person lies a cogni- tive assessment of to what extent their overall quality of life is judged in a favorable way (Veenhoven 1993). People evaluate their level of subjective wellbeing with regard to circumstances and comparisons to other persons, past experience, and expectations of the future. Measures of subjective well-being ${ }^{6}$ can thus serve as proxies for "utility."

Individuals' happiness and life satisfaction can be captured in large surveys. A prominent example of a singleitem question on a three-point scale is in the General Social Surveys (James Davis, Tom Smith, and Peter Marsden 2001), which asks: "Taken all together, how would you say things are these days-would you say that you are very happy, pretty happy, or not too happy?" Life satisfaction is assessed on a scale from one (dissatisfied) to ten (satisfied) in the World Values Survey (Inglehart et al. 2000), which asks: "All things considered, how satisfied are you with your life as a whole these days?" The Eurobarometer Surveys, covering all members of the European Union, asks a similar question: "On the whole, are you very satisfied, fairly satisfied, not very satisfied, or not at all satisfied with the life you lead?" Among the multipleitem approaches, the most prominent is the Satisfaction With Life Scale (William Pavot and Diener 1993), composed of five questions, rated on a scale from one to seven. ${ }^{7}$

\footnotetext{
${ }^{6}$ Subjective well-being is an attitude consisting of the two basic aspects of cognition and affect. "Affect" is the label attached to moods and emotions. Affect reflects people's instant evaluation of the events that occur in their lives. The cognitive component refers to the rational or intellectual aspects of subjective well-being. It is usually assessed with measures of satisfaction. It has been shown that pleasant affect, unpleasant affect, and life satisfaction are separable constructs (Lucas, Diener, and Suh 1996).

${ }^{7}$ For a survey on various measures of subjective well-being, see Frank Andrews and John Robinson (1991).
} 
As subjective survey data are based on individuals' judgements, they are prone to a multitude of systematic and nonsystematic biases. It therefore needs to be checked whether people are indeed capable and willing to give meaningful answers to questions about their well-being. Reported subjective wellbeing may depend on the order of questions, the wording of questions, scales applied, actual mood, and the selection of information processed. The relevance of these errors, however, depends on the intended usage of the data. Often, the main use of happiness measure is not to compare levels in an absolute sense but rather to seek to identify the determinants of happiness. For that purpose, it is neither necessary to assume that reported subjective wellbeing is cardinally measurable nor that it is interpersonally comparable. The subjective data can be treated ordinally in econometric analyses so that higher reported subjective well-being reflects higher well-being of an individual. Whether happiness measures meet this condition has been widely assessed in psychological evaluation studies. ${ }^{8}$ Different measures of happiness correlate well with one another (Meredith Fordyce 1988). Factor analyses of selfand nonself-reports of well-being have revealed a single unitary construct underlying the measures suggesting their validity (Ed Sandvik, Diener, and Larry Seidlitz 1993). Reliability studies indicate that reported subjective wellbeing is moderately stable and sensitive to changing life circumstances (Joop Ehrhardt, Willem Saris, and Veenhoven 2000; and Bruce Headey and Alexander Wearing 1991). Consistency tests reveal

\footnotetext{
${ }^{8}$ Comprehensive discussions of measurement problems are provided in Andrews and Robinson (1991), Michalos (1991), Randy Larsen and Barbara Fredrickson (1999), Schwarz and Strack (1999) and Veenhoven (1993).
}

that happy people smile more often during social interactions (José-Miguel Fernández-Dols and María-Angeles RuizBelda 1995), and are less likely to commit suicide ${ }^{9}$ (Honkanen Koivumaa et al. 2001) and that changes in brain electrical activity and heart rate account for substantial variance in reported negative affect (Richard Davidson et al. 2000). Thus, Diener (1984) in an early survey concluded that the "measures seem to contain substantial amounts of valid variance" (p. 551).

Provided that reported subjective well-being is a valid and empirically adequate measure for human wellbeing, it can be modeled in a microeconometric happiness function $W_{i t}=$ $\alpha+\beta X_{i t}+\varepsilon_{i t}$ that is estimated by ordered probit or logit. Thereby, true well-being serves as the latent variable. $X=x_{1}, x_{2}, \ldots, x_{n}$ are known variables like sociodemographic and socioeconomic characteristics, as well as institutional constraints on individual $i$ at time $t$. The model allows us to analyze each factor that is correlated with reported subjective well-being separately. This approach has been successfully applied in numerous studies on the correlates of happiness. Advanced methods have been used recently in order to address nonrandom measurement errors.

Measurement errors, as well as unobserved characteristics, are captured in the error term $\varepsilon$. They are the source of potential biases as discussed in the following sections on unobserved personality traits and correlated measurement errors. Many mistakes in people's answers, however, are random and thus do

\footnotetext{
${ }^{9}$ Suicide is sometimes considered a more valid measure of happiness because it refers to revealed behavior. But suicide only captures the tail end of the distribution of mental well-being. While this is less of a problem in studying the determinants of low human well-being, it inhibits meaningful statements about average well-being and thus welfare comparisons.
} 
not bias the estimation results. This also holds true for the order of questions, the wording of questions, actual mood, and such.

Nonsampling errors are not always uncorrelated with the variables of interest. A measurement error perspective (Marianne Bertrand and Sendhil Mullainathan 2001; Martin Ravallion and Michael Lokshin 2001) suggests that the inferences can be clouded by unobserved personality traits that influence individuals' sociodemographic and socioeconomic characteristics, as well as how they respond to subjective well-being questions. For instance, people doing voluntary work report higher life satisfaction (Argyle 1999). But volunteering does not necessarily make people happier. If extraverted people volunteer more often, and it is taken into consideration that extraverts tend to report higher satisfaction scores (Kristina DeNeve and Harris Cooper 1998), then the observed correlation is biased. Idiosyncratic effects that are time-invariant, however, can be controlled for if the same individuals are resurveyed over time. In a longitudinal or panel analysis, it is possible to consider a specific baseline well-being for each individual. The statistical relationship between socioeconomic status and reported subjective well-being is then identified by people who change their socioeconomic status. ${ }^{10}$

For some questions, a further reason

${ }^{10}$ In addition to an unbiased estimation of partial correlations, the question of causality arises. In the example mentioned above, the conclusion is that volunteering makes people happy. However, there is evidence that happier people are more willing to contribute to other people's well-being (Myers 1993). Therefore, the observed partial correlation could also mean that happier people do more voluntary work. The direction of causality cannot easily be identified even in a panel data analysis. Additional information from qualitative studies, or in the form of instrumental variables, is necessary. for biases in microeconometric happiness functions may be relevant: the correlation of measurement errors with individual characteristics. For example, young people often report lower life satisfaction scores than old people. On the one hand, this could mean that young people in fact experience lower well-being. On the other hand, it is possible that age has an influence on how people react and respond to questions about their subjective well-being. An observed statistical relationship could then reflect only a spurious correlation. This kind of bias can hardly be overcome by econometric techniques. ${ }^{11}$ It can be mitigated, however, by carefully developed psychological tests and generation of the data.

In addition to the statistical preconditions to study the determinants of happiness discussed so far, further conditions have to be met if welfare comparisons are undertaken on the basis of reported subjective well-being. These conditions are cardinality and interpersonal comparability of the individual statements of well-being. Economists are likely to be skeptical about both claims. ${ }^{12}$ Both of them may be less of a problem on a practical level than on a theoretical level (Kahneman 1999).13 Happy people, for example, are rated as happy by friends and family members (Heidi Lepper 1998; and Sandvik, Diener, and Seidlitz 1993), as well as by spouses (Paul Costa and Robert

${ }^{11}$ Correlated measurement errors are usually no problem for the inclusion of aggregate variables like inflation or democratic rights in microeconomic happiness functions.

12 It should be noted that this skepticism coexists with well-established propositions in the literature on income inequality and poverty, taxation, and risk that implicitly accept cardinal utility measurement and interpersonal comparability.

${ }^{13} \mathrm{Ng}$ (1996) develops a method that yields happiness measures that are comparable interpersonally, intertemporally, and internationally based on the concept of just perceivable increments. 


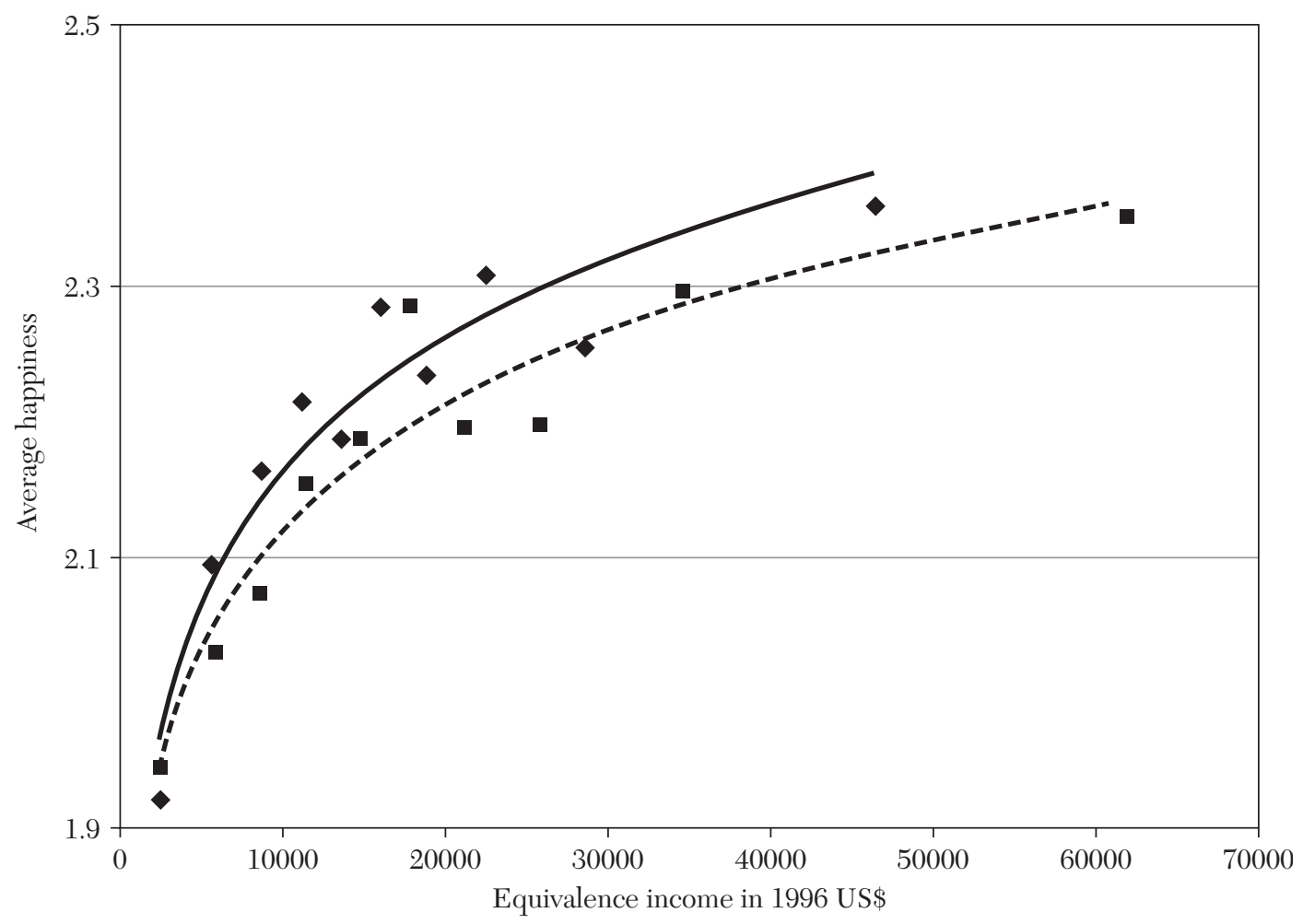

1972-74 1994-96 — Trend 1972-74 ---- Trend 1994-96

Figure 1. Happiness and Equivalence Income in the United States

Source: General Social Survey, National Opinion Research Center.

McCrae 1988). Ordinal and cardinal treatments of satisfaction scores generate quantitatively very similar results in microeconometric happiness functions (Frey and Stutzer 2000). This is consistent with validation results of the income evaluation approach, which focuses on the translation of verbal evaluations into numerical figures in a context-free setting (Bernard van Praag 1991). The meaning of a sequence of verbal labels is about the same for all people in the sample, and the verbal scale is efficiently used, as the underlying intervals are of about equal length. The existing research suggests that, for many purposes, happiness or reported subjective well-being is a satisfactory empiri- cal approximation to individual utility. It is thus possible and worthwhile to study economic effects on happiness.

\section{Effects of Income on Happiness}

In this section, three aspects of the relationship between income and happiness are discussed:

- Are persons with high income at a given point in time happier than those with low income (section 3.1)?

- Does an increase in income over time raise happiness (section 3.2)?

- Are persons in rich countries happier than those in poor countries (section $3.3)$ ? 


\subsection{Happiness and Difference in Income between Persons}

Persons with higher income have more opportunities to achieve what they desire: in particular, they can buy more material goods and services. Moreover, they have a higher status in society. Higher income therefore yields higher utility, and conversely the poor are unhappy. This relationship between income and happiness at a particular point in time and place (country) has been the subject of a large empirical literature. As a robust and general result, it has been found that richer people, on average, report higher subjective wellbeing. ${ }^{14}$ The relationship between income and happiness, both in simple regressions and when a large number of other factors are controlled for in multiple regressions, proves to be statistically (normally highly) significant. In this sense, "income does buy happiness."

For the United States, figure 1 shows the strong positive relationship between (equivalent) real income and happiness in 1972-74 and in 1994-96 (using the General Social Survey data). Average happiness is calculated based on the scores of "not too happy" being equal to 1, "pretty happy" equal to 2 , and "very happy" equal to 3 . Table 1 shows the corresponding data in more detail. In both periods, the mean happiness rating (the higher it is, the happier people are) rises with income. In the lowest decile of income, the mean happiness scores are 1.92 (for 1972-74) and 1.94 (for 1994-96), for the fifth decile the score is 2.19 , and for the tenth and highest decile it is 2.36. In the United States, people with higher income are happier.

14 Blanchflower and Oswald (2000) and Easterlin $(1995,2001)$ for the United States; Di Tella, MacCulloch, and Oswald (2001) for the member countries of the European Union; and Frey and Stutzer (2000) for Switzerland.
Data for Europe from the Eurobarometer Survey Series (1975-91) reveal a similar picture. For example, 88 percent of persons in the upper quartile of the income bracket rate themselves to be "fairly satisfied" or "very satisfied," while 66 percent of those in the lowest income quartile do likewise (see the data presented in Di Tella, MacCulloch, and Oswald 1999).

Additional income, however, does not raise happiness ad infinitum, and not for certain. As may be seen in figure 1, the relationship between income and happiness seems to be nonlinear; there is diminishing marginal utility with absolute income. The data in table 1 also indicate that the same proportional increase in income yields a lower increase in happiness at higher income levels. Within the bottom five deciles, doubling income increases reported happiness, on average, by 0.05 score points in 1994-96; but only by 0.03 score points for the top five deciles. Evidence for diminishing marginal utility is also provided by three successive waves of the World Values Survey covering the years 1980-82, 1990-91, and 1995-97, and including between eighteen and thirty countries (a total of 87,806 observations). It is estimated that for a person moving from the fourth to the fifth decile in the distribution of family income, subjective well-being rises by 0.11 (on a ten-point scale with 1.0 indicating the lowest, and 10.0 the highest level of satisfaction). In contrast, moving from the ninth to the tenth decile increases subjective well-being by only 0.02 (Helliwell 2001, p. 14).

Differences in income explain only a low proportion of the differences in happiness among persons. In the United States, for example, the simple correlation is 0.20 (Easterlin 2001, p. 468). Sometimes these findings are misleadingly interpreted to mean that 
TABLE 1

Happiness AND EQUiVALENCE INCOME IN THE U.S.A.

\begin{tabular}{|c|c|c|c|c|c|c|}
\hline \multirow{2}{*}{$\begin{array}{c}\text { Equivalence Income } \\
\text { (1996 US } \$ \text { ) }\end{array}$} & \multicolumn{2}{|c|}{$\begin{array}{l}\text { Mean Happiness } \\
\text { Rating }^{\mathrm{b}}\end{array}$} & \multicolumn{2}{|c|}{$\begin{array}{l}\text { Mean Equivalence } \\
\text { Income }\end{array}$} & \multicolumn{2}{|c|}{$\begin{array}{l}\text { Number of } \\
\text { Observations }\end{array}$} \\
\hline & $1972-74$ & 1994-96 & $1972-74$ & 1994-96 & $1972-74$ & 1994-96 \\
\hline Full sample & 2.21 & 2.17 & 17434 & 20767 & 4214 & 5171 \\
\hline \multicolumn{7}{|l|}{ Decile } \\
\hline 1 & 1.92 & 1.94 & 2522 & 2586 & 421 & 499 \\
\hline 2 & 2.09 & 2.03 & 5777 & 5867 & 419 & 528 \\
\hline 3 & 2.17 & 2.07 & 8694 & 8634 & 417 & 497 \\
\hline 4 & 2.22 & 2.15 & 11114 & 11533 & 416 & 542 \\
\hline 5 & 2.19 & 2.19 & 13517 & 14763 & 391 & 512 \\
\hline 6 & 2.29 & 2.29 & 15979 & 17666 & 460 & 500 \\
\hline 7 & 2.24 & 2.20 & 18713 & 21128 & 393 & 527 \\
\hline 8 & 2.31 & 2.20 & 22343 & 25745 & 447 & 529 \\
\hline 9 & 2.26 & 2.30 & 28473 & 34688 & 427 & 472 \\
\hline 10 & 2.36 & 2.36 & 46338 & 61836 & 423 & 565 \\
\hline
\end{tabular}

Source: General Social Survey, National Opinion Research Center. Variables 34, 157, and 1028. "Don't know” and "no answer" responses are omitted.

a Total household income divided by the square root of the total number of household members.

b Based on score of "not too happy" = 1, "pretty happy" = 2, and "very happy" $=3$.

income is not relevant for individual happiness. The relevance of income, however, is assessed with regard to the size of the coefficient in a multivariate analysis. A low correlation coefficient might indicate that other factors are also important in explaining why some people are happier than others. ${ }^{15}$ In particular, other economic (in particular unemployment) and noneconomic (in particular health but also personality) factors exert strong influences beyond the indirect consequences on income. A relevant personality factor that might intervene is that individuals who prize material goods more highly than other values in life tend to be substantially less happy (Joseph Sirgy 1997). Similarly, people whose goals are intrinsic, i.e., those who define their values by themselves, tend to be happier than

\footnotetext{
15 The low correlation may, of course, simply reflect substantial random disturbances.
}

those with extrinsic goals, i.e., those oriented toward some external reward, such as financial success or social approval (Tim Kasser and Ryan 2001).

Correlations do not establish causation. It may well be that it is not necessarily higher income that makes people happier, but rather that happier people earn higher income, e.g., because they like to work harder and are more enterprising. In order to test the direction of causation, the effect of windfalls determining income were analyzed. British lottery winners and people receiving an inheritance reported higher mental well-being in the following year. An unexpected transfer of $£ 50,000$ is estimated to raise subjective well-being by between 0.1 and 0.3 standard deviations (Jonathan Gardner and Oswald 2001; also Stephen Smith and Peter Razzell 1975; and Philip Brickman, Dan Coates, and Ronnie Janoff-Bulman 1978). This 
suggests that causation indeed runs from income to happiness.

There may be many different reasons why higher income does not simply translate into higher happiness. Without doubt, one of the most important ones is that individuals compare themselves to other individuals. It is not the absolute level of income that matters most but rather one's position relative to other individuals. This idea of relative income is part of the more general aspiration level theory. Concepts of interdependent preferences due to comparisons with relevant others (see Gary Becker 1974; Frank 1985; and Robert Pollak 1976) supplement ideas focussing on preference changes due to comparison with one's past consumption level or expected future income.

In economics, Easterlin (1974, 1995, 2001) uses the concept of aspirations as a frame of reference to explain happiness. He acknowledges that people with higher income are, on average, happier, but raising everybody's income does not increase everybody's happiness, because in comparison to others income has not improved. This interpretation of the data is supported by laboratory findings showing the importance of relative judgements for happiness (Richard Smith, Diener, and Douglas Wedell 1989, and Amos Tversky and Dale Griffin 1991).

Many economists in the past have noted that individuals compare themselves to significant others with respect to income, consumption, status, or utility. Thorstein Veblen (1899) coined the notion of "conspicuous consumption" serving to impress other persons. The "relative income hypothesis" was formulated and econometrically tested by James Duesenberry (1949), who posited an asymmetric structure of externalities. People look upward when making comparisons. Aspirations thus tend to be above the level reached. Wealthier people impose a negative external effect on poorer people, but not vice versa. As a result, savings rates depend on the percentile position in the income distribution, and not solely on the income level, as in a traditional savings function.

A major line of research known as "individual welfare functions," or the Leyden approach, was opened by van Praag and Arie Kapteyn (1973) and associates (for a recent survey, see van Praag and Paul Frijters 1999). A cardinal relationship between income and welfare is established by asking individuals to add income ranges to a number of qualitatively characterized income levels. ${ }^{16}$ Answering this "income evaluation question," they should take into account their own situation with respect to family and job. Up to nine qualitative descriptions ranging from "excellent" to "very bad" are grouped along an interval scale from 0 to 1 . The bounded scale reflects that the individual welfare function only measures relative welfare as perceived by the individual. Every individual evaluates their income by comparing it with the worst possible situation and the best possible situation of complete satiation. From this information, it is possible to estimate for each individual (i) the income that is required to reach a mean welfare level and (ii) the sensitivity of reported economic welfare to ex ante income changes.

Individual welfare functions have been estimated for several countries with good results, particularly for the Netherlands and Belgium (Floor van

\footnotetext{
${ }^{16}$ For example, "Please try to indicate what you consider to be an appropriate amount for each of the following cases. Under my/our conditions, I would call a net household income per [month] of: about . . . very bad; about . . . very good. Please enter an answer on each line. ..."(van Praag 1993).
} 
Herwaarden, Kapteyn, and van Praag 1977). A particularly interesting aspect is the connection established between the parameter of what people consider "sufficient" income and their actual income, which measures the "preference drift" due to a change in income. A positive correlation suggests that the ex post evaluation of a higher income is smaller than its ex ante evaluation. So what rich people consider a "sufficient" income, for example, is higher than what poor people consider a "sufficient" income. It is found that the preference shift "destroys" about 6080 percent of the welfare effect of an increase in income, so that somewhat less than a third remains. ${ }^{17}$ Individuals anticipate substantial gains in terms of satisfaction from higher income, but in retrospect are often disappointed about the small size of the effects of the gains.

Fred Hirsch (1976), in his book Social Limits to Growth, emphasizes the role of relative social status by calling attention to "positional goods" that, by definition, cannot be augmented because they rely solely on not being available to others. This theme was taken up by Frank $(1985,1999)$ who argues that the production of positional goods in the form of luxuries, such as exceedingly expensive watches or yachts, is a waste of productive resources, as overall happiness is thereby decreased rather than increased.

There is little doubt that people compare themselves to other people and do not use absolute judgements. But it is crucial to know with what other people such a comparison is being made. In a study of five thousand British workers,

\footnotetext{
17 If interdependent preferences are taken into consideration in addition to habit formation, the preference drift seems to outbalance 100 percent of the welfare effect of income gains (Huib van de Stadt, Kapteyn, and Sara van de Geer 1985).
}

Clark and Oswald (1996) formed the reference group comprising persons with the same labor-market characteristics. They conclude that the higher the income of the reference group, the less satisfied people are with their jobs. Social comparisons within the family are studied by David Neumark and Andrew Postlewaite (1998) in order to test the role of relative income for utility. They find that the decision of a woman to go for paid work depends on whether her sisters and sisters-in-law are employed and how much they earn at their jobs.

The effect of the distribution of income on happiness has so far been rarely addressed, mainly due to the lack of suitable data. A fascinating finding by Alberto Alesina, Di Tella, and MacCulloch (2001) suggests that there is a large negative and statistically significant effect from inequality on happiness in Europe, but not in the United States. This may mean that Europeans have a stronger aversion to inequality than Americans have. Alternatively, upward social mobility is perceived to be greater in the United States than in Europe, and therefore being low in the income distribution in the United States is not seen as limiting future income as much.

Most of the research on the relationship between individual income and happiness has been undertaken for advanced industrial countries. Yet Carol Graham and Stefano Pettinato (2001a,b) show that the results essentially carry over to both developing countries and countries in transition. The evidence is consistent with a positive relationship between individual income and happiness within a society at a given point in time. It also emphasizes the relevance of the relative position in the income distribution rather than the absolute level of income. 


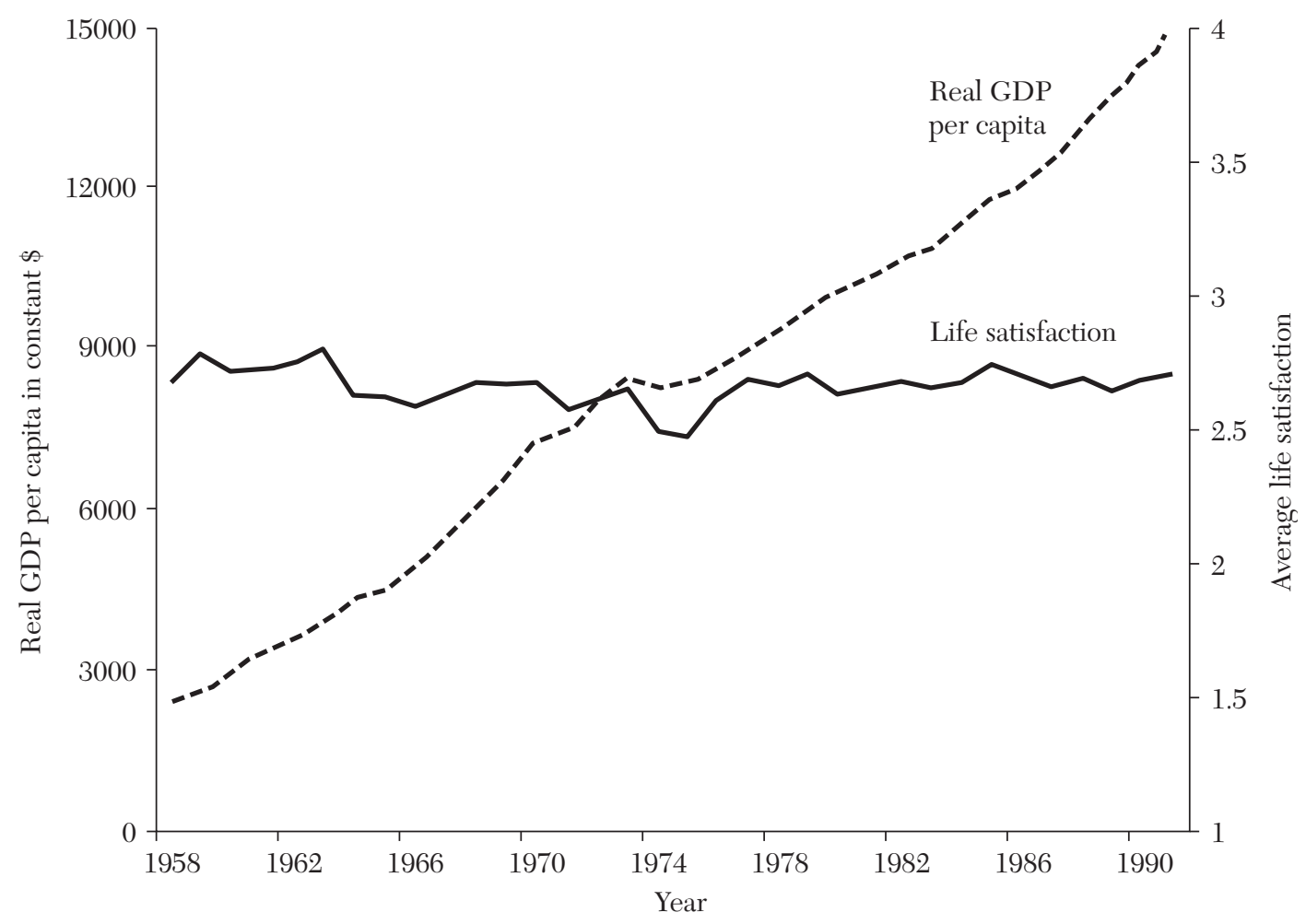

Figure 2. Satisfaction with Life and Income Per Capita in Japan between 1958 and 1991

Sources: Penn World Tables and World Database of Happiness.

\subsection{Income and Happiness over Time}

Several scholars (Blanchflower and Oswald 2000; Diener and Oishi 2000; Myers 2000; Kenny 1999; Lane 1998; and Easterlin 1974, 1995) have identified a striking and curious relationship: per-capita income in western countries like the United States, the United Kingdom, and Belgium, as well as Japan, has risen sharply in recent decades, whereas average happiness has stayed "virtually constant" or has even declined over the same period. Graphically, the development of income and happiness diverges like open scissors. Consider figure 2 for Japan. Between 1958 and 1991, income per capita in Japan rose by a factor of six. This is probably the most spectacular growth in income since World War II. The rise was reflected in almost all households having an indoor toilet, a washing machine, a telephone, a color television, and a car (Easterlin 2000). The open-scissors figure also shows that this tremendous rise in material well-being was not accompanied by an increase in average satisfaction with life. In 1958, average life satisfaction rated on a fourpoint scale was 2.7. In 1991, after more than thirty years of increasing affluence, average life satisfaction still scores 2.7 points.

The same relationship is revealed for the United States in table 1 above. Between 1972-74 and 1994-96, overall mean equivalent real income in the sample increased from $\$ 17,434$ to $\$ 20,767$ (19 percent). But the overall 
mean happiness rating decreased slightly, from 2.21 to 2.17 . Income in all deciles (except the third) increased, yet mean happiness ratings fell or stayed constant in eight of the ten deciles.

What can be inferred from these two cases? One position that can be taken is to disregard the descriptive evidence (i) because other western countries like Denmark, Germany, and Italy experienced substantial real per-capita income growth as well as a (small) increase in reported satisfaction with life in the 1970s and 1980s (Diener and Oishi 2000) and (ii) because whether there is a small increase or decrease in reported subjective well-being depends on the observation period. Moreover, the relationships presented between income and happiness over time are not analyzed ceteris paribus. For the United States, however, a negative time trend occurs when individual characteristics are controlled for (Blanchflower and Oswald 2000). For twelve European countries between 1975 and 1991 there is no correlation between real GDP per capita and life satisfaction, provided individual characteristics as well as the unemployment rate, inflation rate, and income distribution are controlled for (Alesina, Di Tella, and MacCulloch (2001). 18

Another position that can be taken is to accept that there is no clear-cut trend, positive or negative, in selfreported subjective well-being over periods of twenty to thirty years in rich countries. The missing correlation is not due to a changing population. For

\footnotetext{
18 A more fundamental objection could question whether it is in principle possible to capture trends on a closed scale. Valuable complementary evidence could be provided by measures of mental well-being like the General Health Questionnaire (David Goldberg 1972), where much less framing in terms of categories is to be expected.
}

the United States, average happiness of a cohort also remains constant over the life cycle, despite considerable growth in income (Easterlin 2001).

The results can be taken as an indication that there is more to subjective well-being than just income level. One of the most important processes people go through is that of adjusting to past experiences. Human beings are unable and unwilling to make absolute judgements. Rather, they are constantly drawing comparisons from the past or from their expectations of the future. Thus, we notice and react to deviations from aspiration levels.

Additional material goods and services initially provide extra pleasure, but it is usually only transitory. Higher happiness with material things wears off. Satisfaction depends on change and disappears with continued consumption. This process, or mechanism, that reduces the hedonic effects of a constant or repeated stimulus, is called adaptation. And it is this process of hedonic adaptation that makes people strive for ever-higher aspirations.

Adaptation level theory is wellgrounded in psychology (in particular Harry Helson 1964; Brickman and Donald Campbell 1971; Allen Parducci 1995; and, for a modern discussion, Shane Frederick and Loewenstein 1999), as is the concept of aspiration levels (Francis Irwin 1944). According to aspiration level theory, happiness is determined by the gap between aspiration and achievement (Michalos 1991 and Inglehart 1990, ch. 7). In economics, the theories of preference change have concentrated on habit formation (Alfred Marshall 1890; Duesenberry 1949; Franco Modigliani 1949; Robert Pollack 1970; and more recently Christopher Carroll and David Weil 1994). There are three important consequences: 


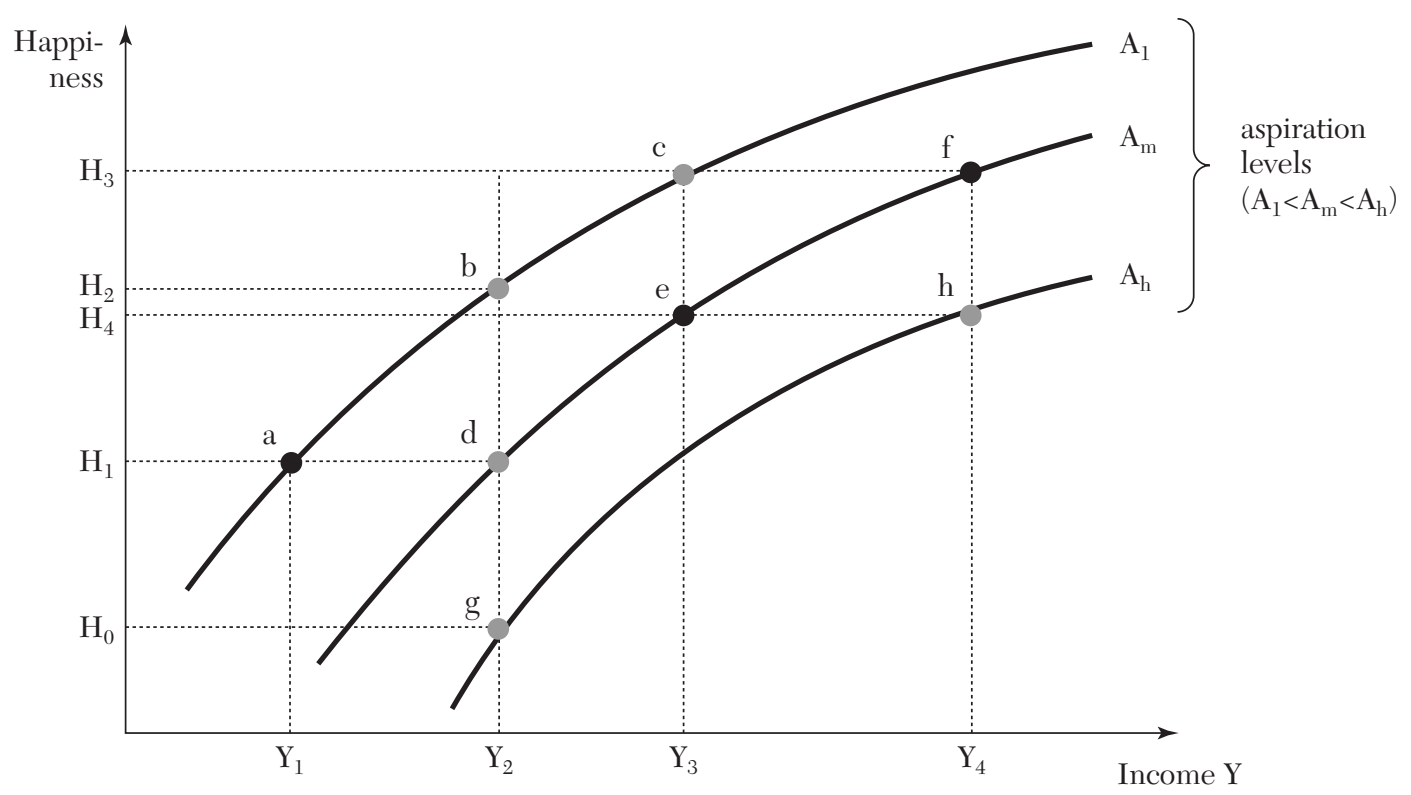

Figure 3. Happiness, Income, and the Role of the Aspiration Level

(1) The upward adjustment of aspirations induces human beings to accomplish more and more. They are never satisfied. Once they have achieved something, they want to achieve even more. The theory of "rising aspirations" does not hold only for material goods and services but also for many immaterial achievements. A promotion, for example, makes for temporary happiness, but at the same time raises the expectation and aspiration for further promotions.

(2) Wants are insatiable. The more one gets, the more one wants. The marginal utility of income is thus not defined anymore in this framework, as the utility function changes with the income level.

(3) Most people think that they felt less happy in the past, but expect to be more happy in the future (Easterlin 2001). This asymmetry can be explained by changing aspirations, as will be illustrated below.
The effects of changes in income affecting aspiration levels are illustrated in figure 3 (see Easterlin 2001).

Initially, people have a certain aspiration level $A_{l}$ so that income $Y_{1}$ produces happiness $H_{1}$. Raising income, say from $Y_{1}$ to $Y_{2}$, raises happiness from $H_{1}$ to $H_{2}$. If it rises further, say to $Y_{3}$, happiness is further increased to $H_{3}$. The points $a, b$, and $c$ trace a curve with decreasing marginal utility of income, as normally assumed in economic theory. This curve holds for a particular point in time. It suggests that higher income indeed makes people happier.

But, over time, aspiration adjusts to the higher income level. The aspiration level curve $A_{l}$ shifts downward to $A_{m}$. Ex post, the rise in income from $Y_{1}$ to $Y_{2}$ does not produce any increase in happiness if the aspiration curve indeed shifts as much downward as assumed in the graph. If the increase in income jacks up aspirations even higher, say to the aspiration curve $A_{h}$, income $Y_{2}$ 
produces even less happiness than the lower income $Y_{1}$.

Aspiration level theory suggests that increases in income and aspiration levels are closely connected. The increase in happiness expected on the basis of a given aspiration curve-for example along the points $a, b$, and $c$ on aspiration curve $A_{l}$-does not materialize. Rather, an increase in income is accompanied by a downward shift in the aspiration curve. In equilibrium, one may observe, for example, that the sequence of points- $a, e$, and $f$ materializes. As the curves are drawn, higher income matches higher happiness, but an increase in income produces a much smaller increase in happiness than with given aspiration levels.

As indicated above, the figure helps to explain the asymmetry in evaluations of happiness referring to the past and to the future. A person with income $Y_{3}$ judges her past happiness on the basis of the current aspiration level $A_{m}$. As income has risen, say from $Y_{2}$ to $Y_{3}$, the previous income is evaluated to have produced happiness $H_{1}$ at point $d$, which is lower than today's happiness level $H_{4}$, as given at point $e$. Current happiness is thus taken to be higher than in the past. In actual fact, when the individuals actually received income $Y_{2}$, they had a lower aspiration level and therefore that income actually produced happiness $\mathrm{H}_{2}$ in the past, which in our figure is even higher than today's happiness $\mathrm{H}_{4}$.

Future income is also evaluated on the basis of the current aspiration level. Let's take the case of a person situated at point $e$ with income $Y_{3}$ and happiness $H_{4}$. The person anticipates that an increase in income from $Y_{3}$ to $Y_{4}$ produces a well-being along curve $A_{m}$, so that happiness $\mathrm{H}_{3}$ at point $f$ is to be expected. But the person does not take into account that the aspiration level also rises and that the aspiration curve will therefore shift downward, say to curve $A_{h}$. In actual fact, therefore, when the higher income $Y_{4}$ is indeed reached, the level of happiness is only $H_{4}$ at point $h$, and not $H_{3}$ as would have been the case if the aspiration level had stayed constant at point $f$. The actual happiness of the increase in income is thus systematically lower than expected beforehand (in our figure 3, happiness even stays constant).

\subsection{Income and Happiness between Different Countries}

Various studies provide evidence that, on average, persons living in rich countries are happier than those living in poor countries (for example Diener, Marissa Diener, and Carol Diener 1995; Inglehart 1990). The differences in income between the countries are measured by using exchange rates and purchasing power parities to control for the international differences in the cost of living. Data on happiness are usually from the World Values Survey, the best source available today for international comparisons of life satisfaction (Inglehart et al. 2000).

Figure 4 illustrates the relationship between income per capita and average life satisfaction in 51 countries for data from the two waves of the World Values Survey in the 1990s. The figure shows that reported subjective well-being seems to rise with income. Some of the authors identify a concave relationship: income provides happiness at low levels of development but once a threshold (around $\$ 10,000)$ is reached, the average income level in a country has little effect on average subjective well-being.

A visual inspection of the relationship between income and happiness across countries, however, is of limited value. The positive correlation may be produced by factors other than income 


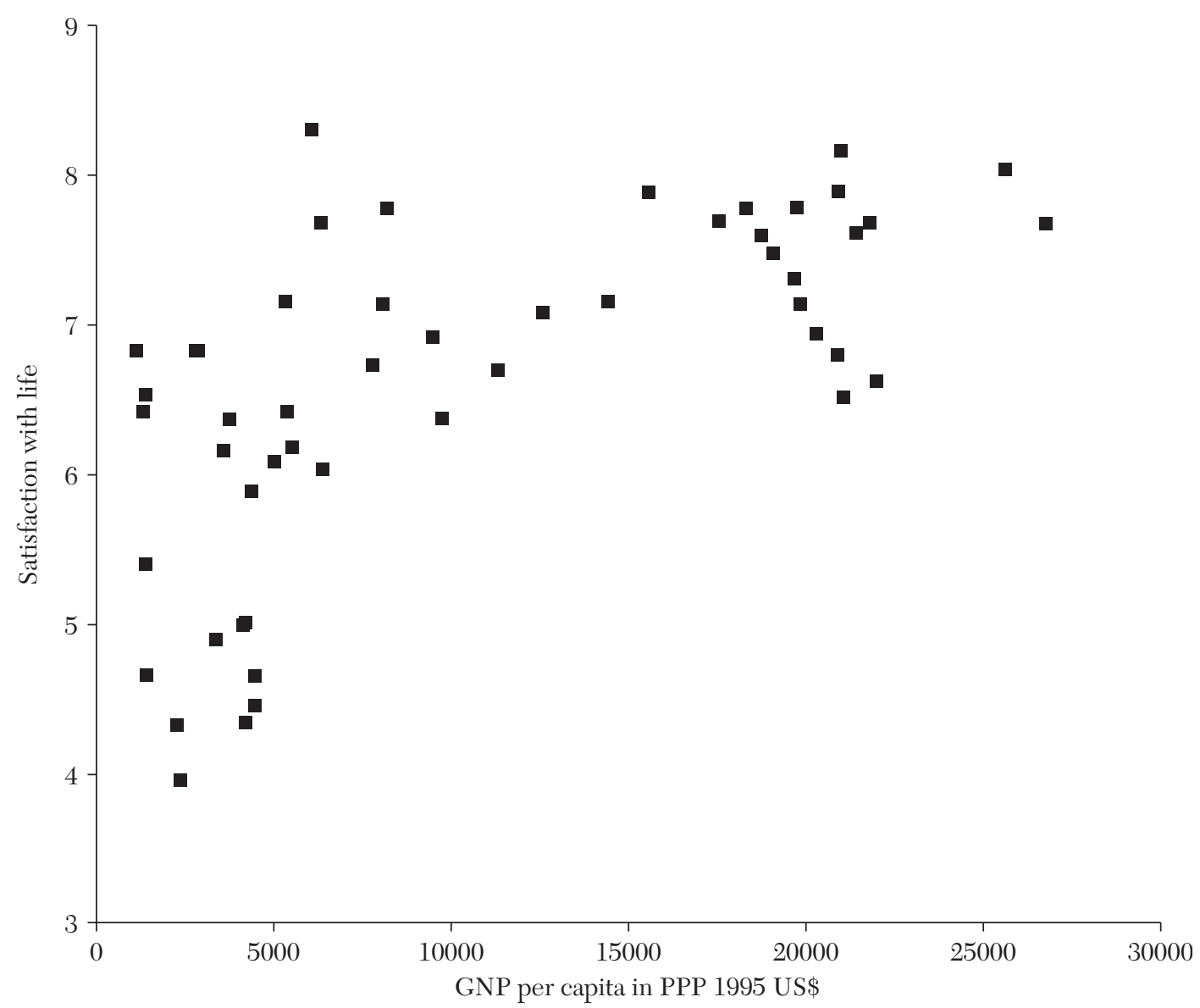

Figure 4. Life Satisfaction and Income Levels Across the World in the 1990s

Sources: World Values Survey 1990-93/1995-97 (ICPSR 2790) and World Development Report 1997.

alone. In particular, countries with higher per-capita incomes tend to have more stable democracies than poor countries. So it may well be that the seemingly observed positive association between income and happiness is in reality due to more developed democratic conditions (see section 6).

In addition to democracy, there may be other conditions correlated with income that produce the observed positive correlation between income and happiness. To mention two more: the higher the income is, the better the average health and the more secure the basic human rights. Thus, both health and basic human rights may make happiness rise with income.

Moreover, the positive correlation may come as a surprise in light of evidence presented for happiness over time, where no robust relationship between income per capita and happiness is found. There are two possible strategies to further address the role of absolute income in happiness in and between countries. First, cross-sectional data for several periods can be combined in order to allow a control of time-invariant country-specific characteristics. These characteristics could comprise stable cultural differences, 
systematic distortions due to language differences, and so on. Such an approach is followed in the study mentioned earlier combining data for 49 countries from the first three waves of the World Values Survey. Instead of country specific effects, separate base levels for six groups of countries are taken into consideration in the estimation equation: industrial countries, Scandinavia, countries of the former Soviet Union, other countries of Eastern Europe, Latin American countries, and other developing countries. ${ }^{19}$ The study found that national income per capita (measured in percentage of the value for 1997 in the United States) has a very small effect on reported subjective well-being. A 10percent increase in per-capita incomes in a country with half the level of the United States (and unchanged income distribution) raises average satisfaction with life by only 0.0003 score points on a scale from one to ten, and the gain disappears even before the U.S. 1997 level of real per-capita income is achieved (Helliwell 2001, p. 15).

This evidence is more in line with the findings for income and happiness over time than with previous results from cross-section studies that neglected country- or region-specific determinants of reported subjective well-being. It may be argued that poor countries are not adequately represented in the data pool. As the relationship between income and happiness seems relevant, especially from a development perspective, a second strategy could directly address subjective well-being in developing countries. But extended time series about reported subjective well-being in developing countries with strong economic growth are lacking so far. Prom-

19 The strategy of constructing groups of countries is chosen in order to allow more degrees of freedom in the statistical analysis. ising projects are a socioeconomic panel in Russia (Ravallion and Lokshin 2001) and repeated surveys in seventeen Latin American countries (Graham and Pettinato 2001b). First evidence for Peru and Russia indicates that economic development is accompanied by extensive social mobility and, for some people with rapidly increasing aspiration levels, that may depress overall wellbeing gains from increased economic wealth. While perceived past mobility and prospects of upward mobility have a positive effect on reported subjective well-being, there is a fraction of "frustrated achievers" that, in spite of objective mobility, reports negative perceived mobility and low satisfaction with life (Graham and Pettinato 2001a).

Another aspect to consider is whether, when income and happiness between countries are compared, causality runs from income to well-being, as implicitly assumed so far. The reverse causality can well be imagined (see Kenny 1999). It could be argued that the more satisfied the population is with its life, the more it is inclined to work hard, and therefore the higher is its per-capita income. In other words, happy people may be more creative and enterprising, leading again to higher income. This line of argument has not yet been well studied but should be seriously considered in the future.

The available evidence suggests that across nations income and happiness are correlated but that the effects are small and diminishing. This indicates that, on the one hand, other factors may be more important in explaining differences in reported subjective well-being between countries; on the other hand, the notion that people in poor countries are happier because they live under more "natural" and less stressful conditions is a myth. 


\section{Effects of Unemployment on Happiness}

Two questions and their ramifications will be discussed in this section:

- What is the level of happiness of an unemployed person (section 4.1)?

- How does general unemployment in an economy affect happiness (section $4.2)$ ?

\subsection{Personal Unemployment}

Reports on subjective well-being help to identify the level of utility of unemployed people. How particular people are affected when they become unemployed has been studied with individual data for twelve European countries over the period 1975-91, employing Eurobarometer data on satisfaction with life on a four-point scale (Di Tella, MacCulloch, and Oswald 2001). The analysis, which controls for a large number of other determinants of happiness, such as income and education, finds that the self-proclaimed happiness of unemployed persons is much lower than employed persons with otherwise similar characteristics. The loss of subjective well-being experienced through unemployment amounts to 0.33 units in the satisfaction scale, which ranges from 1 ("not at all satisfied") to 4 ("very satisfied").

Many other studies for different countries and time periods have similarly found that personally experiencing unemployment makes people very unhappy. ${ }^{20}$ In their study for Britain, Clark and Oswald (1994, p. 655) summarize their result as "joblessness depressed well-being more than any other

20 Anders Björklund and Tor Eriksson (1998) for Scandinavian countries; Blanchflower and Oswald (2000) for the United Kingdom and the United States; Thomas Korpi (1997) for Sweden; Ravallion and Lokshin (2001) for Russia; and William Darity and Arthur Goldsmith (1996) for a survey. single characteristic, including important negative ones such as divorce and separation." Some analyses offer additional results for particular groups of unemployed people. While the picture is not totally consistent, many studies find that unemployment on average weighs more heavily on men than on women. Younger and older employees suffer less when hit by unemployment than employees in the middle of their working lives. For Germany, unemployment does not reduce satisfaction with life of women over fifty (Knut Gerlach and Gesine Stephan 1996). People with high education experience a larger decrease in their subjective well-being due to unemployment than employees with low education (Clark and Oswald 1994).

All these results refer to the "pure" effect of being unemployed. The income loss, as well as other indirect effects which may, but need not, go with personally being unemployed, are controlled for.

These findings could be interpreted quite differently. While the negative correlation between unemployment and happiness is well established, it may well be that the causality runs in the opposite direction: unhappy people do not perform well and therefore get laid off. Happy persons are fitter for working life, which makes it less likely that they will lose their jobs. The question of reverse causality due to selection bias has been analyzed in many studies with longitudinal data, before and after particular workers lose their jobs (for example due to plant closure). There is evidence that unhappy people do not perform well on the labor market, but the main causality seems clearly to run from unemployment to unhappiness (see Winkelmann and Winkelmann 1998 for German panel data; Gary Marks and Nicole Fleming 1999 for 
Australian panel data, with detailed consideration of various effects on mental health). ${ }^{21}$

As the lower subjective well-being of unemployed people can be explained neither by the lower income level nor the self selection of intrinsically lesshappy people, unemployment has to be related to non-pecuniary costs. The drop in happiness may be attributed to a large extent to psychological and social factors (see the survey by Norman Feather 1990):

- Psychic Cost. Unemployment produces depression and anxiety, and results in a loss of self-esteem and personal control. Especially for persons very involved in their work, not having a job is a heavy blow. Numerous studies have established (see Goldsmith, Jonathan Veum, and Darity 1996) that the unemployed are in worse mental (and physical) health than working people. As a result, they are subject to a higher death rate, more often commit suicide 22 and are more prone to consuming large quantities of alcohol. Their personal relationships are also more strained.

The psychic cost is considerably higher for those made redundant for the first time. In contrast, persons who have been unemployed more often in the past suffer less, that is, to some extent they get used to being unemployed.

\footnotetext{
${ }^{21}$ Studies in social psychology also identify effects of unemployment and re-employment on mental well-being. Studies that explicitly control for individual heterogeneity with a longitudinal design are Mary Dew, Evelyn Bromet, and Lili Penkower (1992), and Brian Graetz (1993). For a recent survey, see Gregory Murphy and James Athanasou (1999).

22 A recent study using longitudinal data for the United States for 1972-91 found that state unemployment rates are significantly positively related to the number of suicides. A 1-percentage-point increase in state unemployment rates predicts an increase of suicides by 1.3 percent (Christopher Ruhm 2000).
}

This finding may to some extent explain persistent unemployment (Clark, Yannis Georgellis, and Peter Sanfey 2001).

- Social Cost. Being unemployed has a stigma attached to it, particularly in a world in which one's work essentially defines one's position in life. This aspect will be further discussed in the following section.

\subsection{General Unemployment}

People may be unhappy about unemployment even if they are not themselves out of work. They may feel bad about the unfortunate fate of those unemployed and they may worry about the possibility of becoming unemployed themselves in the future. They may also feel repercussions on the economy and society as a whole. They may dislike the increase in unemployment contributions and taxes likely to occur in the future; they may fear that crime and social tension will increase; and they may even see the threat of violent protests and uprisings.

The study of twelve European countries over the period 1975-91 mentioned above (Di Tella, MacCulloch, and Oswald 2001) finds that-keeping all other influences constant-a 1percentage-point increase in the general rate of unemployment from 9 percent (the European mean) to 10 percent reduces stated life satisfaction by 0.028 units on the four-point scale applied. This effect is considerable. This small rise in unemployment is equivalent to shifting more than 2 percent of the population downward from one lifesatisfaction category to another, for example from "not very satisfied" to "not at all satisfied."

The overall effect of unemployment on social well-being can be calculated by adding the loss experienced by the unemployed persons to the overall 
effect of unemployment. Consider again a 1-percentage-point increase in unemployment. In the previous section we discussed that the unemployed experience a decrease of 0.33 in their happiness scale. This figure must be multiplied by the 1 percent of the population unfortunate enough to actually become unemployed: $0.33 \times 0.01=0.0033$. Added to the general effect of a 1-percentagepoint unemployment increase of 0.028 , it leads to a total decrease of 0.0313 (Di Tella, MacCulloch, and Oswald 2001).

This calculation must be taken with a grain of salt. It is at best able to approximately gauge the effects of unemployment on happiness. One reason for caution is that there may be various interactions between personal and more general unemployment that may in turn affect the evaluation of happiness.

An important interaction refers to reference groups. As is the case for income, individuals tend to evaluate their own situation relative to other persons. For most persons, unemployment lowers their happiness less if they are not alone in their fate. When unemployment is seen to hit many persons one knows or hears of, both the psychic and the social effects are mitigated. Selfesteem is better preserved because it seems that being out of a job is less one's own fault and more due to general developments in the economy. Stigma and social disapproval are less prevalent if unemployment hits many others at the same time.

In order to empirically test the effect of reference groups on reported wellbeing, happiness scores have been regressed on three types of explanatory variables: personal unemployment; unemployment among a reference group; and an interaction variable combining personal and reference group unemployment.

Using as a reference group the employment state of one's partner or the region an individual lives in, Clark (2000) has estimated such a happiness function for British data over the period 1991-96, again keeping all other influences constant. As in virtually all previous studies, the unemployed are much more dissatisfied than people with jobs, and the general level of unemployment lowers happiness. In contrast, the unemployed indeed suffer less when the partner and/or a larger proportion of other people in their region are also out of work. The same result holds when general unemployment in the economy is taken as the point of reference (Peter Kelvin and Joanna Jarrett 1985).

Unemployed people's well-being, moreover, depends on the strength of the social norm to work. Social interaction of unemployed people with other community members, the reference group forced upon themselves, has the effect of showing them how they are expected to behave, and norm-conforming behavior is enforced through social sanctions. An estimation across Swiss communities shows that the stronger the social norm to live off one's own income, the lower the unemployed people's reported satisfaction with life (Stutzer and Rafael Lalive 2001).

Reference groups are of major importance for showing the extent to which people are distressed by their own unemployment. The group one refers to is not given, but can to some extent be chosen (Armin Falk and Markus Knell 2000). People out of work tend to associate with other people out of work, partly because they have time to do so, and partly because they retreat from normal community life. It is also clear that marriages and partnerships have a high risk of breaking down when one partner is unemployed. In all these cases, the definition of the reference group adjusts to one's labor market status. Causation then does not run 
unambiguously from the reference group to the evaluation of unemployment in terms of happiness.

\section{Effects of Inflation on Happiness}

In combined time-series and crosssection studies, the development of inflation in several countries over the course of time can be analyzed. Of most interest is the study of twelve European countries over the period 1975-91 (Di Tella, MacCulloch, and Oswald 2001). The mean rate of inflation was 7.5 percent per year. Based on an econometric estimate that keeps individual socioeconomic characteristics and the unemployment rate constant, increasing the inflation rate by one percentage pointsay from the mean rate of 8 to 9 percent per year-appears to reduce average happiness by 0.01 units of satisfaction, i.e., from an average level in the sample of 3.02 to 3.01. (Average satisfaction is calculated from a cardinal interpretation of the 4-point scale that attributes to "not at all satisfied" a value of 1, "not very satisfied" a value of 2 , etc.). Correspondingly, increasing the inflation rate by 5 percentage points (which historically is quite a likely event) reduces subjective well-being by 0.05 units. This is a substantial effect. It means that 5 percent of the population is shifted downward from one life-satisfaction category to the next lower one, e.g. from being "very satisfied" to "fairly satisfied."

In order to study the trade-off between inflation and unemployment, the results reported on the effect of unemployment on happiness and the effects of inflation can be combined (Di Tella, MacCulloch, and Oswald 2001). The question is by how much, on average, must a country reduce its inflation in order to tolerate a rise of 1 percentage point in unemployment? Over the rele- vant range, happiness is assumed to depend linearly on these two economic factors, and the estimate controls for country fixed-effects, year effects, and country-specific time trends. A 1percentage-point increase in the unemployment rate is compensated for by a 1.7-percentage-point decrease in the inflation rate. Thus, if unemployment rises by 5 percentage points (say from 3 to 8 percent), the inflation rate must decrease by 8.5 percentage points (say from 10 to 1.5 percent per year) to keep the population equally satisfied. The socalled "misery index," which simply adds the unemployment rate to the inflation rate, distorts the picture by attributing too little weight to the effect of unemployment, relative to inflation, on self-reported happiness.

\section{Institutional Effects on Happiness}

\subsection{Basic Constitutional Rules}

People's happiness is influenced by the kind of political system they live in. It should be expected that people living in constitutional democracies are happier because the politicians are more motivated to rule according to their interests. If they disregard the wishes of the population, the politicians and parties in a democracy fail to be reelected and hence lose their power. Democratic institutions, in particular the right to participate in elections and vote on issues, thus contribute to citizens' happiness.

Researchers on happiness have looked at the interaction between democracy and happiness. The extent to which a constitution is democratic and allows its citizens to make decisions according to their own preferences can be captured by various indices of freedom.

Figure 5 presents a graphical representation of a comprehensive measure of freedom, combined with a 4-point 


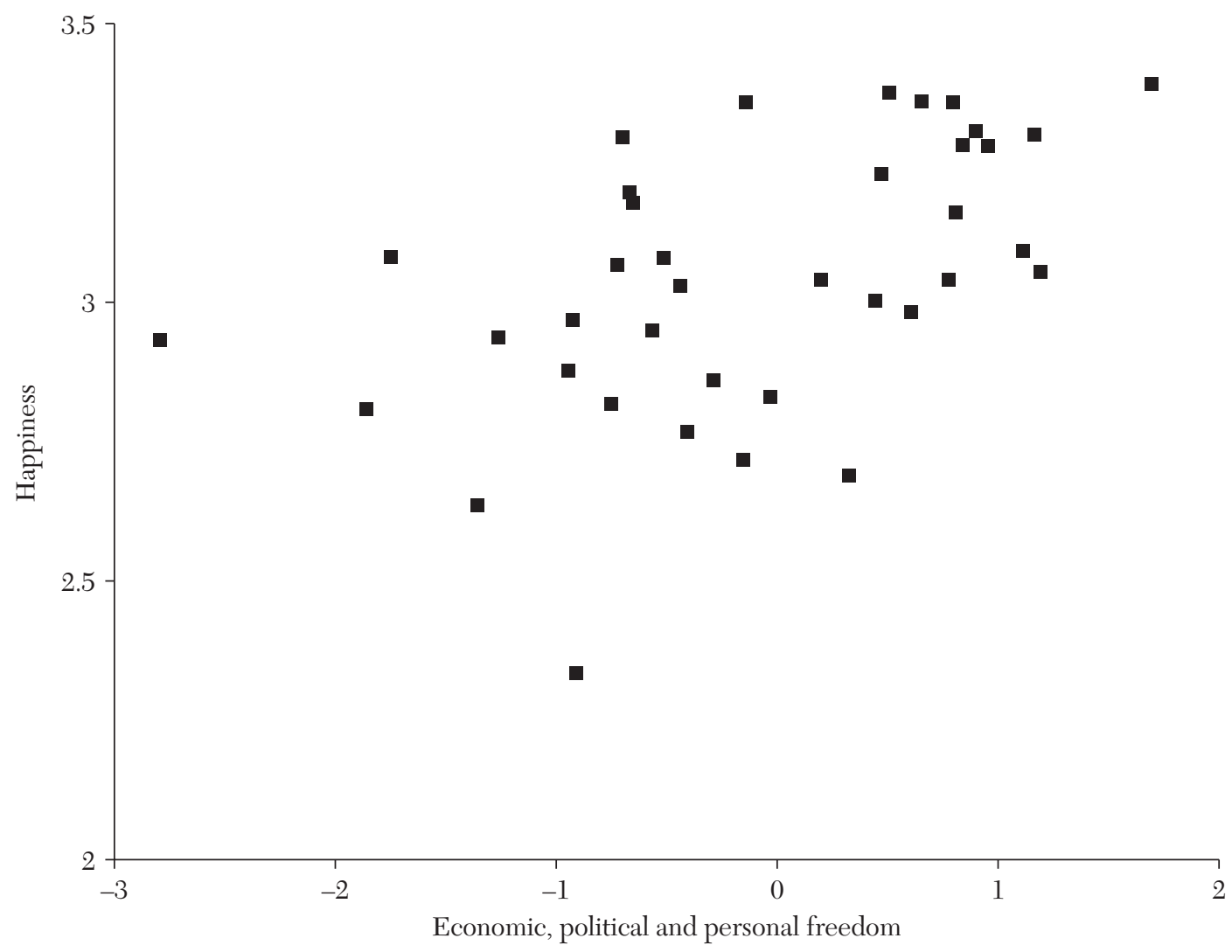

Figure 5. Freedom and Happiness across Nations

Source: Veenhoven (2000), Appendix 1.

measure of happiness, in 38 mainly developed nations at the beginning of the 1990s (Veenhoven 2000). A visual test reveals that freedom and happiness are positively related. The comprehensive index of the constitutional set-up used in this figure refers to the following three areas:

- Political freedom measures the possibility for citizens to engage in the democratic process or, conversely, the restrictions on political participation. It is composed of two sub-indices, the first relating to civil rights, such as freedom of speech (with eleven items), and the second to political rights (nine items).

- Economic freedom measures the op- portunity for individuals to engage in the free exchange of goods, services, and labor. It is based on sub-indices (each in turn composed of a number of items), referring to the security of money, free enterprise, freedom from excessive taxation, and the possibility of undertaking monetary transfers.

- Personal freedom measures how free one is in one's private life, for example, to practice one's religion, to travel, or to get married.

To combine the sub-indices, average z-scores are calculated. All threepolitical, economic, and personal freedom-are strongly and statistically significantly correlated with happiness (Veenhoven 2000). Controlling for 
differences in per-capita income, the correlation with economic, but not political and personal, freedom remains statistically significant. Analyses with subsamples suggest that economic freedom contributes to happiness particularly in poor countries with a low level of general education, while political freedom is more strongly correlated with subjective well-being in rich countries with a high level of education. In both cases, differences in income per capita are controlled for (Veenhoven 2000).

Such studies are certainly illuminating, but they can only inform us in a limited way about the influence of various constitutional conditions on subjective well-being. Countries differ from each other in many ways, and it is not sufficient simply to control for unequal per-capita incomes to capture the influence of democracy. Moreover, the crosssection studies only report correlations and do not deal with causation. Even if we ignore the other problems, it remains open whether democracy fosters happiness, or whether happiness is a precondition for democracy. It has been argued, for instance, that high satisfaction with life in a population increases the legitimacy of the political regime in power and it may thus foster democracy (Inglehart 1990, 1999). For Latin America and Russia, one study (Graham and Pettinato 2001b) indeed identified a mutual dependence of pro-democracy and pro-market attitudes with wellbeing: both raise happiness, but happier people are also more likely to have prodemocratic and pro-market attitudes. With due caution, it may be hypothesized that, for the respective respondents, there is a virtuous circle in which attitudes favorable to democracy, to the market, and to life satisfaction reinforce each other.

In the following, we concentrate on specific institutions of democracy in one particular country. This removes many problems, which may arise due to the difficulties of internationally comparing happiness scores and their determinants across countries.

\subsection{Referenda}

The possibility for citizens to directly participate in politics is an important feature of democracy. The constitutions of many countries allow popular referenda, but they are sometimes only used as a device to inform the government when it no longer knows what to do. Often it is used as a plebiscite in which the voters are asked to support the government's policy. In many cases, it is restricted to local and sometimes trivial issues, while the decisions on important issues are reserved for the professional political actors in parliament and government. In the United States, there are many popular referenda at the local level as well as in some states (especially in California), but the constitution does not allow them at the national level. The only country with an extensive set of direct political participation rights at all levels of government, and with respect to all issues, is Switzerland. Of the 728 referenda made in the world at the national level between 1900 and 1993, 357 (or almost 50 percent) were held in Switzerland (see David Butler and Austin Ranney 1994).

A referendum, in which all the citizens have the possibility to participate, meets the crucial requirement that it gives decision-making power to people outside of the group of (professional) politicians. The constitutional setting determines to a large extent what issues are put on the political agenda, and what issues are prevented from appearing. In representative democracies, politicians are often very skilled at not 
letting issues that are to their disadvantage be discussed in the democratic institutions. For example, they usually succeed in not having their privileges (e.g., their incomes and pensions) discussed in open parliamentary sessions. In direct democracies, in which the citizens may put any issue on the ballot, the agenda is much less under the control of the classe politique.

The effect of direct democracy on various aspects of society has been carefully analyzed in a number of econometric studies for the United States. Findings include:

- Government expenditure and revenues are lower in institutions with direct democracy (John Matsusaka 1995);

- Per-capita debt is substantially lower with a referendum requiring a qualified majority (William McEachern 1978);

- Land prices are higher because people find it attractive to live and work in such communities (Rexford Santerre 1986);

- Public expenditures for education are higher when a referendum is possible (Santerre 1989).

The following insights have been gained on the basis of econometric studies for Switzerland:

- A comparison of Swiss communes with different degrees of institutionalized forms of participation in political decisions reveals that the outcomes correspond more closely to the voters' preferences, the more directly democratic they are (Werner Pommerehne 1990);

- The growth of public expenditure is more strongly determined by demand factors (i.e., by the citizens' willingness to pay) than by supply factors (in particular by the politicians' and bureaucrats' own interests) (Pommerehne and Friedrich Schneider 1978);
- Public supply is less costly, the more direct the democratic institutions are (Pommerehne 1978);

- Tax morale is higher than in representative democracies (Pommerehne and Hannelore Weck-Hannemann 1996; Frey 1997);

- Per-capita incomes in cantons with more-developed direct participation possibilities for citizens are significantly higher than in cantons with lessdeveloped forms of direct participation (Lars Feld and Marcel Savioz 1997).

All these results control for a great number of variables unrelated to direct democracy. They provide strong evidence that deviation from citizens' preferences is indeed significantly lower in a referendum compared to a representative democracy.

The influence of direct democracy on happiness has been analyzed using data on reported subjective well-being for Switzerland in 1992-94 (Frey and Stutzer 2000). The major explanatory variable is the institutionalized right of individual political participation via popular referenda, which varies considerably between the 26 Swiss cantons. The estimates reveal that the extent of direct democratic participation possibilities exerts a statistically significant, robust, and sizeable effect on happiness over and above the demographic and economic determinants normally taken into account. When the full variation in the institutional variable is considered, i.e., when individuals in the canton with the highest democracy index (Basel Land) are compared to citizens in the canton with the lowest direct-participation rights (Geneva), the former state with an 11-percentage-points higher probability that they are completely satisfied. This effect is larger than living in the top rather than in the bottom income category. 


\subsection{Federalism}

The decentralization of decision making is an alternative means for better fulfillment of the voters' preferences: individuals tend to leave dissatisfying jurisdictions, while they are attracted to those caring for the population's preferences at low cost. The possibility to vote with one's feet (Charles Tiebout 1956; see also James Buchanan 1965; and Albert Hirschman 1970) tends to undermine regional cartels by politicians. The division of competence between communities and the state government, or the extent of fiscal decentralization, is thus another constitutional factor systematically influencing happiness. The study on Switzerland (Frey and Stutzer 2000) measured the extent of local autonomy by an index based on survey results. Chief local administrators in 1,856 Swiss municipalities reported on how they perceived their local autonomy using a 10-point scale. The estimate reveals a statistically significant positive effect of decentralization on subjective well-being. For local autonomy, the proportion of people who indicate being completely satisfied with life increases by 2.6 percentage points, compared to a situation in which the communes are one standard deviation less autonomous vis-à-vis their canton.

\section{Summary and Implications}

\subsection{What Economists Can Learn}

The insights gained from research on happiness throw new light on important issues analyzed in economics. Most important, they enlarge the scope of empirical measurement and provide new tests for theories.

Happiness is not identical to the traditional concept of utility in economics. It is, however, closely related. On the one hand, the concept of subjective happiness is a valuable complementary approach, which covers many more aspects of human well-being than the standard concept of utility. On the other hand, subjective well-being can be considered a useful approximation to utility, which economists have avoided measuring explicitly. This allows us to empirically study problems that previously were analyzed only on an abstract theoretical level. Moreover, the analysis of data on subjective well-being may allow for discrimination between competing explanations for empirical findings in behavior (for an application, see Stutzer and Lalive 2001). The opportunities offered by information on well-being and affect may not only enrich field research, but also laboratory research in experimental economics (Gary Charness and Brit Grosskopf 2001 and James Konow and Joseph Earley 1999). These extensions represent a considerable step forward toward a social science able to provide useful information.

\subsection{Implications for Economic Policy}

The insights gained about happiness are in many respects useful for economic policy undertaken by governments. Some examples suffice to illustrate the point:

- The use of measures of happiness allows for a new way of evaluating the effects of government expenditure. All too often, the effect is measured by the cost incurred by the state: the more spent, the better. This is obviously not always the case, and in some instances lower expenditure would be better. The problem has been approached scientifically by using benefit-cost analysis. The benefits are the recipients' marginal willingness to pay, which is best measured in surveys by contingent valuation analysis. This method can be complemented by 
simulations using micro-econometric happiness functions with a large number of determinants that allow for the evaluation of the widespread effects of extensive expenditure policies.

- Welfare policy faces the question of how much economic destitution is responsible for people's unhappiness. To what extent can persons with low income be helped by financial support? If low income is due to unemployment, the research results suggest that providing people with higher incomes can only compensate for the pecuniary effect. In order to improve well-being, policy should rather be directed toward providing appropriate employment.

- An important part of antipoverty policy deals with the question of what "poverty" is. Traditionally, the definition relies on disposable income. Happiness research allows the problem to be approached more fundamentally by considering reported levels of subjective well-being. Such complementary measurement also allows equivalence scales to be established (Erik Plug and van Praag 1995). They indicate the increase in income necessary to compensate for a larger family, while maintaining the subjective well-being of the family.

- Tax policy must consider to what extent various income groups are affected. Is it possible to achieve social goals by redistributing income, or are the negative effects on subjective wellbeing prohibitive? Recently it has been argued that the fight for relative positions is socially wasteful, and that the high-income recipients, as winners of these status races, should be more heavily taxed (Frank 1999; more generally Layard 1980). This proposal has been influenced by the findings of happiness research, which suggest that people derive more satisfaction from their position in comparison to other income recipients than from the income level as such. If the redistributive tax policy is able to make this race less attractive, subjective well-being may be positively affected. But, for an overall evaluation, this proposal must consider many additional aspects, in particular what possibilities the highincome recipients have to evade increased taxes.

Happiness functions have sometimes been looked at as the best existing approximation to a social welfare function to be maximized (explicitly Di Tella, MacCulloch, and Oswald 2001, p. 340). The optimal values of the determinants thus derived are-according to this view-the goals economic policy should achieve. It seems that, at long last, the so far empirically empty social welfare maximization of the quantitative theory of economic policy (Jan Tinbergen 1956, and Henry Theil 1964) is given a new lease on life.

Such an endeavor is still confronted with fundamental problems of social welfare maximization (Frey 1983, pp. 182-94). While the shortcoming of empirical emptiness has been overcome (provided one is prepared to accept happiness functions as a reasonable approximation to a social welfare function), the government still has little or no incentive to pursue such a policy. Only a "benevolent dictator" government would do so (Geoffrey Brennan and Buchanan 1985). Empirical analyses in public choice (Dennis Mueller 1997) suggest that governments are not benevolent and do not simply follow the wishes of the population, even in wellfunctioning democracies, not to mention authoritarian and dictatorial governments. Hence, to maximize the happiness function neglects the crucial incentive aspect. Therefore, the insights from empirical analyses should serve 
mainly as information on favorable economic and institutional conditions. If they are considered to be convincing by political entrepreneurs and citizens, they are taken up and are proposed in the political process.

\subsection{Implications for Economic Theory}

Happiness research adds considerable new insights to well-known theoretical propositions. This has been shown with the example of how income, unemployment, inflation, and democracy affect reported individual well-being.

Effects of income. Most economists take it as a matter of course that higher income leads to higher happiness. A higher income expands individuals' and countries' opportunity set, i.e., more goods and services can be consumed. The few people not interested in more commodities need not consume them; they are free to costlessly dispose of any unwanted surplus. It therefore seems obvious that income and happiness go together (provided, of course, that the two are correctly measured).

But there are also some economists who do not subscribe to the idea that higher income produces higher happiness. One of them is John Kenneth Galbraith who, in his famous book The Affluent Society (1958), pointed out the limited use of higher private income while the public sector is starving. In the first serious economic study of the data on happiness, Easterlin (1974) concluded that "money does not buy happiness." Another author claiming that the most cherished values cannot be bought on markets is Tibor Scitovsky with his Joyless Economy: The Psychology of Human Satisfaction (1976). Scitovsky even argues that a high level of wealth brings continuous comforts and thereby prevents the pleasure that results from incomplete and intermittent satisfaction of desires. More re- cently, Frank, in his Luxury Fever (1999), emphasizes that ever-increasing income and consumption do not bring higher happiness.

The empirical research on happiness has clearly established that at a given point in time, and within a particular country, persons with higher income are happier. Over time, however, happiness in western countries and Japan does not systematically increase, despite considerable growth in real percapita income. This can be attributed to the rise in aspiration levels going with increases in income. Between countries, and at per-capita income levels much below the United States, higher average income goes with higher average happiness, but the improvements in reported subjective well-being seem to be rather small.

Effects of unemployment. There are two quite different views about unemployment in economics. According to the "new classical macroeconomics," unemployment is voluntary. People choose to leave employment because they find the burden of work and the wage paid unattractive compared to being unemployed and getting unemployment benefits. Other economists take unemployment to be an unfortunate event to be avoided as much as possible. For them, to become unemployed is considered to be burdensome and, above all, involuntary. For those affected, becoming unemployed is considered to be a most unfortunate event. Happiness research suggests that unemployment strongly reduces subjective self-reported well-being, both personally and for society as a whole. This is more in line with the view that unemployment is involuntary for the bulk of people affected.

Effects of inflation. The costs of an increase in the general price levelinflation-are discussed in theoretical 
economics on the a priori notions based on the distinction between anticipated and unanticipated inflation. When price increases are anticipated, individuals can adjust to them with little, if any, cost, while they cannot when they come as a "shock." Adjustment is all the more costly, the higher is the variability in aggregate inflation and in relative prices caused by an increase in inflation. People then must invest a lot of effort to inform themselves about, and to insulate themselves from, the expected price increases. They may make many different errors, for instance in underestimating the extent of future inflation, or how a particular price changes in comparison with other prices.

Depending on a set of (rather restrictive) assumptions, the welfare costs of rising prices can be captured by computing the appropriate area under the money demand curve, the basic idea being that economizing on the use of currency imposes costs in terms of wellbeing. They are reflected indirectly by the demand for money curve. Based on this method, the cost of a 10-percent yearly inflation was calculated to be between 0.3 percent and 0.45 percent of national income (Stanley Fischer 1981; Robert Lucas 1981). This is very little, and suggests that an anti-inflationary policy rarely is worth the cost it entails in terms of additional unemployment and real income loss.

But many economists would strongly disagree with this conclusion. They point out that stable prices are a crucial prerequisite for a sound economy in which suppliers and demanders can act rationally. Most economists take an intermediate position, not least because the picture emerging from the existing empirical evidence on the costs of inflation is far from clear (see the survey by John Drifill, Grayham Mizon, and
Alistair Ulph 1990). The "common opinion" of academic economists probably is that rampant inflation is very dangerous for the economy, while a constant, and hence predictable, but low inflation (say 1-5 percent per year) is not taken to cause any major problems.

The population seems to feel quite differently. An extensive survey in the United States, Germany, and Brazil (Robert Shiller 1997) finds that people are concerned about quite different issues connected with inflation than are economists. People seem to disregard the fact that inflation probably also raises their own nominal income. They obviously concentrate on the possible harm, but not on the possible benefits, of inflation on their standard of living. In addition, the survey identifies other concerns generally neglected by economists. One is that inflation allows opportunists to exploit others in an unfair and dishonest way; another is that inflation undermines the moral basis of society. Many fear that inflation produces political and economic chaos and a loss in national prestige due to the falling exchange rate.

Happiness research finds that inflation systematically and sizeably lowers reported individual well-being. In European countries, the effect on happiness of a 1-percentage-point increase in unemployment is compensated by a 1.7percentage-point decrease in inflation. The relative size of inflation is thus smaller than in the "misery index," which attaches equal weight to both percentage changes.

Effects of democracy. Consequences of democratic rule have mainly been analyzed in economics with regard to their effects on economic growth. Data on subjective well-being allow us to look at the interaction between democracy and happiness. The extent to which a 
constitution is democratic and allows its citizens to make decisions according to their own preferences can be captured by various measures which indicate that increased possibilities to directly participate in public decision-making via popular referenda and a decentralized state significantly contribute to happiness.

\subsection{Open Issues}

The research on happiness undertaken thus far leaves many questions open. At the same time it opens up challenging new areas. Further progress is especially needed in four areas:

Effects of happiness on behavior. Economists have mainly studied the effects of behavior on subjective wellbeing, as represented by variables such as unemployment, inflation, and income. The reverse effect has so far received scant attention (for a theoretical investigation see Benjamin Hermalin and Alice Isen 1999). In the following, we present some ideas for future research that are particularly relevant from the economic point of view.

The extent of happiness may influence many important economic decisions. Examples are:

- Consumption activities. Happy individuals are more likely to save and spend different proportions of their income, to distribute spending differently over time, and to acquire different combinations of particular goods and services than do less-happy persons (Barbara Kahn and Isen 1993).

- Work behavior. Happier individuals may differ significantly in their behavior on the job. A large literature on job satisfaction (e.g. Peter Warr 1999) analyzes whether more-satisfied workers are also more productive (Michelle Iaffaldano and Paul Muchinsky 1985).

- Investment behavior. It can be hypothesized that happier individuals have a different attitude to taking risks than less-happy individuals. They may also prefer different markets and types of financial investments.

- Political behavior. Happy individuals are likely to vote for different politicians and parties, and for different alternatives in referenda, than unhappy individuals. It has been found, for instance, that such a difference exists where attitudes toward the European Union are concerned (Francis Castles 1998).

Application of happiness analysis on further areas. There are many topics in economic research for which a complementary analysis of survey data on subjective well-being would be worthwhile. Possible questions are:

- Discrimination of women. Is there a relationship between discrimination of women on the labor market and their life satisfaction (Clark 1997; and Alfonso Sousa-Poza and Andrés Sousa-Poza 2000)?

- Quality of life indicators. How are various quality of life indicators like crime, environmental quality, traffic accidents, commuting, etc. related to subjective well-being (Michalos and Bruno Zumbo 2000)?

- Growth analysis. Are there systematic differences in measures of subjective well-being for different paths of growth or development (Kenny 1999)?

Special emphasis may be put on a broader set of institutions. Studies on the impact of institutions on happiness have so far mainly been confined to two elements, namely (direct) democracy and federalism. They certainly count among the most important basic aspects of a constitution, but there are many other institutions whose impact on subjective well-being is worth studying. Examples would be the institutions of 
monetary policy, such as the extent of independence of the central bank; the importance of corporatism in policy making; and the prevalence of centralized or firm-level wage bargaining between trade unions and employer associations.

Application of More Advanced Methods. Most comparative studies of happiness between countries employ multiple cross-section regressions. This has been a very useful starting point, but the next important step is to use panel data. The spread of this technique in happiness research is still poor (exceptions are Ravallion and Lokshin 2001, and Winkelmann and Winkelmann 1998), mostly because of the lack of necessary data on happiness. Another advanced method is demographers' cohort analysis technique for life cycle studies. Its application in happiness research is only just beginning (in particular in the work of Easterlin 2001).

Improved Happiness Measurements. There is also room for improvement in the quality of the happiness data (Diener et al. 1999, pp. 277-78) as well as in its systematic collection. In particular, there is still a lack of data on subjective well-being in developing and transition countries. Repeated surveys with equal single- or multi-item scales in these countries would render superfluous the questionable technique of merging responses to different happiness questions.

Economists should not be too critical, however, in view of the deficiencies of what they traditionally measure and use as indicators for individual and aggregate welfare. National income, whose shortcomings are obvious, is a case in point.

This paper has reached its goal if it has convinced the reader that happiness research is not a futile or eccentric activity but rather can provide relevant new insights and can serve as an inspiration for future research in economics.

\section{REFERENCES}

Alesina, Alberto; Rafael Di Tella, and Robert MacCulloch. 2001. "Inequality and Happiness: Are Europeans and Americans Different?" NBER work. paper 8198 .

Allen, Roy G. D. 1934. "A Reconsideration of the Theory of Value, II," Economica 1, pp. 196219.

Andrews, Frank M. and John P. Robinson. 1991. "Measures of Subjective Well-Being," in Measures of Personality and Social Psychological Attitudes. John P. Robinson, Phillip R. Shaver and Lawrence S. Wrightsman, eds. San Diego: Academic Press, pp. 61-114.

Argyle, Michael. 1987. The Psychology of Happiness. London: Methuen.

1999. "Causes and Correlates of Happiness," in Kahneman, Diener and Schwarz, op. cit., pp. 353-73.

Becker, Gary S. 1974. "A Theory of Social Interactions," J. Polit. Econ. 82:6, pp. 1063-93.

-Bertrand, Marianne and Sendhil Mullainathan. 2001. "Do People Mean What They Say? Implications for Subjective Survey Data," Amer. Econ. Rev. 91:2, pp. 67-72.

Björklund, Anders and Tor Eriksson. 1998. "Unemployment and Mental Health: A Survey of Nordic Research," Scand. J. Social Welfare 7, pp. 219-35.

Blanchflower, David G. 1996. "Youth Labor Markets in Twenty-Three Countries: A Comparison Using Micro Data," in School to Work Policies and Practices in Thirteen Countries. David Stern, ed. Cresskill: Hampton Press.

Blanchflower, David G. and Andrew J. Oswald. 2000. "Well-Being over Time in Britain and the USA," NBER work. paper 7487.

Boskin, Michael and Eytan Sheshinski. 1978. "Optimal Redistributive Taxation When Individual Welfare Depends on Relative Income," Quart. J. Econ. 92:4, pp. 589-601.

Brennan, Geoffrey and James M. Buchanan. 1985. The Reason of Rules. Constitutional Political Economy. Cambridge: Cambridge U. Press.

Brickman, Philip and Campbell Donald T. 1971. "Hedonic Relativism and Planning the Good Society," in Adaptation Level Theory: A Symposium. Mortimer H. Appley, ed. NY: Academic Press, pp. 287-304.

Brickman, Philip, Dan Coates, and Ronnie JanoffBulman. 1978. "Lottery Winners and Accident Victims: Is Happiness Relative?” J. Personality Social Psych. 36:8, pp. 917-27.

Buchanan, James M. 1965. "An Economic Theory of Clubs," Economica 32:1, pp. 1-14.

Butler, David and Austin Ranney, eds. 1994. Referendums around the World. The Growing Use of Direct Democracy. Washington, DC: AEI Press.

Carroll, Christopher D. and David N. Weil. 1994. 
"Saving and Growth: A Reinterpretation," Carnegie-Rochester Conf. Ser. Public Pol. 40:0, pp. 133-92.

Castles, Francis G. 1998. "Die Bedeutung der Oekonomie für die politische Unterstützung der Europäischen Union," in Europa der Bürger? Voraussetzungen, Alternativen, Konsequenzen. Thomas König, Elmar Rieger and Hermann Schmitt, eds. Frankfurt: Campus Verlag, pp. 159-76.

Charness, Gary and Brit Grosskopf. 2001. "Relative Payoffs and Happiness: An Experimental Study,"J. Econ. Behav. Org. 45:3, pp. 301-28.

Clark, Andrew E. 1997. "Job Satisfaction and Gender: Why Are Women So Happy at Work?" Lab. Econ. 4:4, pp. 341-72.

2000. "Unemployment as a Social Norm: Psychological Evidence from Panel Data," mimeo, U. Orléans, France.

Clark, Andrew E. and Andrew J. Oswald. 1994. "Unhappiness and Unemployment," Econ. J. 104:424, pp. 648-59.

- 1996. "Satisfaction and Comparison Income," J. Public Econ. 61:3, pp. 359-81.

- 1998. "Comparison-Concave Utility and Following Behaviour in Social and Economic Settings," J. Public Econ. 70:1, pp. 133-55.

Clark, Andrew E.; Yannis Georgellis and Peter Sanfey. 2001. "Scarring: The Psychological Impact of Past Unemployment," Economica 68:270, pp. 221-41.

Costa, Paul T. and Robert R. McCrae. 1988. "Personality in Adulthood; A Six-Year Longitudinal Study of Self-Reports and Spouse Ratings on the NEO Personality Inventory," J. Personality Social Psych. 54:5, pp. 853-63.

-Darity, William and Arthur H. Goldsmith. 1996. "Social Psychology, Unemployment and Macroeconomics," J. Econ. Perspect. 10:1, pp. 121-40.

Davidson, Richard J.; John R. Marshall, Andrew J. Tomarken, and Jeffrey B. Henriques. 2000. "While a Phobic Waits: Regional Brain Electrical and Autonomic Activity in Social Phobics During Anticipation of Public Speaking," Biological Psychiatry 47:2, pp. 85-95.

Davis, James A.; Tom W. Smith, and Peter V. Marsden. 2001. General Social Survey, 19722000: Cumulative Codebook. Storrs, CT: Roper Center for Public Opinion Research.

DeNeve, Kristina M. and Harris Cooper. 1998. "The Happy Personality: A Meta-Analysis of 137 Personality Traits and Subjective WellBeing," Psych. Bull. 124:2, pp. 197-229.

Dew, Mary Amanda; Evelyn J. Bromet and Lili Penkower. 1992. "Mental Health Effects of Job Loss in Women," Psych. Medicine 22:3, pp. 751-64.

Di Tella, Rafael; Robert J. MacCulloch and Andrew J. Oswald. 1999. "How Do Macroeconomic Fluctuations Affect Happiness?" mimeo, Harvard Business School.

- 2001. "Preferences over Inflation and Unemployment: Evidence from Surveys of Happiness," Amer. Econ. Rev. 91:1, pp. 335-41.
Diener, Ed. 1984. "Subjective Well-Being," Psych. Bull. 95:3, pp. 542-75.

Diener, Ed; Marissa Diener and Carol Diener. 1995. "Factors Predicting the Subjective WellBeing of Nations," J. Personality Social Psych. $69: 5$, pp. $851-64$.

Diener, Ed and Shigehiro Oishi. 2000. "Money and Happiness: Income and Subjective WellBeing Across Nations," in Culture and Subjective Well-Being. Ed Diener and Eunkook M. Suh, eds. Cambridge: MIT Press, pp. 185-218.

Diener, Ed; Eunkook M. Suh, Richard E. Lucas and Heidi L. Smith. 1999. "Subjective WellBeing: Three Decades of Progress," Psych. Bull. 125:2, pp. 276-303.

Drifill, John; Grayham E. Mizon and Alistair Ulph. 1990. "Costs of Inflation," in Handbook of Monetary Economics. Benjamin M. Friedman and Frank H. Hahn, eds. Vol. II. Amsterdam: North-Holland, pp. 1014-66.

Duesenberry, James S. 1949. Income, Savings and the Theory of Consumer Behavior. Cambridge: Harvard U. Press.

Easterlin, Richard A. 1974. “Does Economic Growth Improve the Human Lot? Some Empirical Evidence," in Nations and Households in Economic Growth: Essays in Honor of Moses Abramowitz. Paul A. David and Melvin W. Reder, eds. NY: Academic Press, pp. 89-125.

- 1995. "Will Raising the Incomes of All Increase the Happiness of All?" J. Econ. Behav. Org. 27:1, pp. 35-48.

- 2000. "The Worldwide Standard of Living Since 1800," J. Econ. Perspect. 14:1, pp. 7-26. 2001. "Income and Happiness: Towards a Unified Theory," Econ. J. 111:473, pp. 465-84.

Ehrhardt, Joop J.; Willem E. Saris and Ruut Veenhoven. 2000. "Stability of Life-Satisfaction over Time," J. Happiness Stud. 1:2, pp. 177-205.

Elster, Jon. 1998. "Emotions and Economic Theory,” J. Econ. Lit. 36:1, pp. 47-74.

Falk, Armin and Markus Knell. 2000. "Choosing the Joneses: On the Endogeneity of Reference Groups," Institute for Empirical Research in Econ., U. Zurich, work. paper 59.

Feather, Norman T. 1990. The Psychological Impact of Unemployment. NY: Springer.

Feld, Lars P. and Marcel R. Savioz. 1997. "Direct Democracy Matters for Economic Performance: An Empirical Investigation," Kyklos 50:4, pp. 507-38.

Fernández-Dols, José-Miguel and María-Angeles Ruiz-Belda. 1990. "Are Smiles a Sign of Happiness? Gold Medal Winners at the Olympic Games," J. Personality Social Psych. 69:6, pp. 1113-19.

Fischer, Stanley. 1981. "Towards an Understanding of the Costs of Inflation: II," Carnegie-Rochester Conf. Ser. Public Pol. 15:0, pp. 5-41.

Fordyce, Meredith A. 1988. "A Review of Research on Happiness Measures: A Sixty Second Index of Happiness and Mental Health," Soc. Indicators Res. 20, pp. 355-81. 
Frank, Robert H. 1985. Choosing the Right Pond. NY: Oxford U. Press. 1997. "The Frame of Reference as a Public Good," Econ. J. 107:445, pp. 1832-47. 1999. Luxury Fever. Why Money Fails to Satisfy in an Era of Excess. NY: Free Press.

Frederick, Shane and George Loewenstein. 1999. "Hedonic Adaptation," in Kahneman, Diener, and Schwarz, op. cit., pp. 302-29.

Frey, Bruno S. 1983. Democratic Economic Policy. Oxford: Blackwell.

—_ 1997. "A Constitution for Knaves Crowds Out Civic Virtues," Econ. J. 107:443, pp. 1043-53.

Frey, Bruno S. and Alois Stutzer. 1999. "Measuring Preferences by Subjective Well-Being," Z . ges. Staatswissens. (JITE) 155:4, pp. 755-88. 2000. "Happiness, Economy and Institutions," Econ. J. 110:446, pp. 918-38.

2002. Happiness and Economics: How the Economy and Institutions Affect Human Well-Being. Princeton: Princeton U. Press.

Galbraith, John Kenneth. 1958. The Affluent Society. Harmondsworth: Penguin Books.

Gardner, Jonathan and Andrew J. Oswald. 2001. "Does Money Buy Happiness? A Longitudinal Study Using Data on Windfalls," mimeo, Warwick U.

Gerlach, Knut and Gesine Stephan. 1996. “A Paper on Unhappiness and Unemployment in Germany," Econ. Letters 52:3, pp. 325-30.

Goldberg, David P. 1972. The Detection of Psychiatric Illness by Questionnaire. Oxford: Oxford U. Press.

Goldsmith, Arthur; Jonathan R. Veum and William Darity Jr. 1996. "The Impact of Labor Force History on Self-Esteem and its Component Parts, Anxiety, Alienation and Depression," J. Econ. Psych. 17:2, pp. 183-220.

Graetz, Brian. 1993. "Health Consequences of Employment and Unemployment: Longitudinal Evidence for Young Men and Women," Social Science and Medicine 36:6, pp. 715-24.

Graham, Carol and Stefano Pettinato. 2001a. "Frustrated Achievers: Winners, Losers, and Subjective Well Being in New Market Economies,"J. Devel. Stud. forthcoming.

2001b. "Happiness, Markets, and Democracy: Latin America in Comparative Perspective," J. Happiness Stud. 2:3, pp. 237-68.

Headey, Bruce and Alexander Wearing. 1991. "Subjective Well-Being: A Stocks and Flows Framework," in Strack, Argyle and Schwarz, op. cit., pp. 7-26.

Helliwell, John F. 2001. “How's Life? Combining Individual and National Variables to Explain Subjective Well-Being," mimeo, U. British Columbia.

Helson, Harry. 1964. Adaptation-Level Theory: An Experimental and Systematic Approach to Behavior. NY: Harper and Row.

Hermalin, Benjamin E. and Alice M. Isen. 1999. "The Effect of Affect on Economic and Strategic Decision-Making," mimeo, U. Cal. Berkeley.
-Hicks, John R. 1934. "A Reconsideration of the Theory of Value, I," Economica 1, pp. 52-75.

Hirsch, Fred. 1976. The Social Limits to Growth. Cambridge, MA: Harvard U. Press.

Hirschman, Albert O. 1970. Exit, Voice and Loyalty. Cambridge, MA: Harvard U. Press.

Holländer, Heinz. 2001. "On the Validity of Utility Statements: Standard Theory versus Duesenberry's," J. Econ. Behav. Org. 45:3, pp. 227-49.

Iaffaldano, Michelle T. and Paul M. Muchinsky. 1985. "Job Satisfaction and Job Performance: A Meta-Analysis," Psych. Bull. 97:2, pp. 251-73.

Inglehart, Ronald F. 1990. Culture Shift in Advanced Industrial Society. Princeton: Princeton U. Press.

1999. "Trust, Well-Being and Democracy," in Democracy and Trust. Mark E. Warren, ed. Cambridge, UK: Cambridge U. Press, pp. $88-120$.

Inglehart, Ronald et al. 2000. World Values Surveys and European Values Surveys, 1981-84, 1990-93, 1995-97 [computer file]. ICPSR version. Ann Arbor: Institute for Social Research, 1999.

Irwin, Francis W. 1944. "The Realism of Expectations," Psych. Rev. 51, pp. 120-26.

Kahn, Barbara E. and Alice M. Isen. 1993. "The Influence of Positive Affect on Variety Seeking among Safe, Enjoyable Products," J. Cons. Res. 20:2, pp. 257-70.

Kahneman, Daniel. 1999. "Objective Happiness," in Kahneman, Diener and Schwarz, op. cit., pp. $3-25$.

Kahneman, Daniel; Ed Diener and Norbert Schwarz, eds. 1999. Well-Being: The Foundations of Hedonic Psychology. New York: Russell Sage Foundation.

Kahneman, Daniel; Peter P. Wakker, and Rakesh Sarin. 1997. "Back to Bentham? Explorations of Experienced Utility," Quart. J. Econ. 112:2, pp. 375-405.

Kasser, Tim and Richard M. Ryan. 2001. "Be Careful What You Wish For: Optimal Functioning and the Relative Attainment of Intrinsic and Extrinsic Goals," in Life Goals and Well-Being. Towards a Positive Psychology of Human Striving. Peter Schmuck and Kennon M. Sheldon, eds. Kirkland, WA: Hogrefe and Huber, pp. 116-31.

Kelvin, Peter and Joanna E. Jarrett. 1985. The Social Psychological Effects of Unemployment. Cambridge: Cambridge U. Press.

Kenny, Charles. 1999. "Does Growth Cause Happiness, or Does Happiness Cause Growth?" Kyklos 52:1, pp. 3-26.

Koivumaa, Honkanen Heli; Risto Honkanen, Heimo Viinamaeki, Kauko Heikkilae, Jaakko Kaprio and Markku Koskenvuo. 2001. "Life Satisfaction and Suicide: A 20-Year Follow-up Study," Amer. J. Psychiatry 158:3, pp. 433-39.

Konow, James and Joseph Earley. 1999. "The Hedonistic Paradox: Is Homo Economicus Happier?" mimeo, Loyola Marymount U.

Korpi, Tomas. 1997. "Is Well-Being Related to Employment Status? Unemployment, Labor 
Market Policies and Subjective Well-Being among Swedish Youth," Lab. Econ. 4:2, pp. $125-47$.

Lane, Robert E. 1998. "The Joyless Market Economy," in Economics, Values, and Organization. Avner Ben-Ner and Louis Putterman, eds. Cambridge: Cambridge U. Press, pp. 461-88.

Lane, Robert E. 2000. The Loss of Happiness in Market Economies. New Haven, London: Yale U. Press.

Larsen, Randy J. and Barbara L. Fredrickson. 1999. "Measurement Issues in Emotion Research," in Kahneman, Diener, and Schwarz, op. cit., pp. 40-60.

Layard, Richard. 1980. "Human Satisfactions and Public Policy," Econ. J. 90:363, pp. 737-50.

Le Menestrel, Marc. 2001. "A Process Approach to the Utility for Gambling," Theory Dec. 50:3, pp. 249-62.

Lepper, Heidi S. 1998. "Use of Other-Reports to Validate Subjective Well-Being Measures," Soc. Indicators Res. 44:3, pp. 367-79.

Loewenstein, George. 1999. "Because It Is There: The Challenge of Mountaineering . . . for Utility Theory," Kyklos 52:3, pp. 315-43.

Loewenstein, George; Ted O'Donoghue and Matthew Rabin. 2000. "Projection Bias in Predicting Future Utility," mimeo, Carnegie-Mellon U.

Lucas, Robert E. Jr. 1981. "Discussion of: Stanley Fischer, 'Towards an Understanding of the Costs of Inflation: II', Carniegie-Rochester Conf. Ser. Public Choice 15:0, pp. 43-52.

Lucas, Richard E., Ed Diener and Eunkook M. Suh. 1996. "Discriminant Validity of Well-Being Measures," J. Personality and Social Psychology 71:3, pp. 616-28.

Marks, Gary N. and Nicole Fleming. 1999. "Influences and Consequences of Well-being among Australian Young People: 1980-1995," Soc. Indicators Res. 46:3, pp. 301-23.

Marshall, Alfred. 1890. The Principles of Economics. 8th ed., 1920. London: Macmillan.

Matsusaka, John G. 1995. "Fiscal Effects of the Voter Initiative: Evidence from the Last 30 Years," J. Polit. Econ. 103:2, pp. 587-623.

McEachern, William A. 1978. "Collective Decision Rules and Local Debt Choice: A Test of the Median Voter Hypothesis," Nat. Tax J. 31:2, pp. 129-36.

Michalos, Alex C. 1991. Global Report on Student Well-Being. Volume 1: Life Satisfaction and Happiness. NY: Springer.

Michalos, Alex C. and Bruno D. Zumbo. 2000. "Criminal Victimization and the Quality of Life," Soc. Indicators Res. 50:3, pp. 245-95.

Modigliani, Franco. 1949. Fluctuations in the Saving-Income Ratio: A Problem in Economic Forecasting. Conference on Research in Income and Wealth, NY.

Mueller, Dennis C., ed. 1997. Perspectives on Public Choice. Cambridge: Cambridge U. Press. Murphy, Gregory C. and James A. Athanasou. 1999. "The Effect of Unemployment on Mental Health," J. Occup. Org. Psych. 72:1, pp. 83-99.
Myers, David G. 1993. The Pursuit of Happiness: Who Is Happy and Why? NY: Avon.

2000. "The Funds, Friends, and Faith of Happy People," Amer. Psychologist 55:1, pp. 56-67.

Neumark, David and Andrew Postlewaite. 1998. "Relative Income Concerns and the Rise in Married Women's Employment," J. Public Econ. 70:1, pp. 157-83.

Ng, Yew-Kwang. 1996. "Happiness Surveys: Some Comparability Issues and an Exploratory Survey Based on Just Perceivable Increments," Soc. Indicators Res. 38:1, pp. 1-27.

1997. "A Case for Happiness, Cardinalism, and Interpersonal Comparability," Econ. J. 107:445, pp. 1848-58.

2001. "From Preference to Happiness: Towards a More Complete Welfare Economics," mimeo, Monash U.

Oswald, Andrew J. 1997. "Happiness and Economic Performance," Econ. J. 107:445, pp. $1815-31$.

Parducci, Allen. 1995. Happiness, Pleasure, and Judgment: The Contextual Theory and Its Applications. Hillsdale, NJ: Erlbaum.

Pavot, William and Ed Diener. 1993. "The Affective and Cognitive Context of Self-Reported Measures of Subjective Well-Being," Soc. Indicators Res. 28:1, pp. 1-20.

Plug, Erik J. S. and Bernard M. S. van Praag. 1995. "Family Equivalence Scales within a Narrow and Broad Welfare Context," J. Income Distrib. 4:2, pp. 171-86.

Pollak, Robert A. 1970. "Habit Formation and Dynamic Demand Functions," J. Polit. Econ. 78:4, pp. 745-63.

Pommerehne, Werner W. 1978. "Institutional Approaches to Public Expenditure: Empirical Evidence from Swiss Municipalities," J. Public Econ. 9:2, pp. 225-80.

1990. "The Empirical Relevance of Comparative Institutional Analysis," Europ. Econ. Rev. 34:2-3, pp. 458-69.

Pommerehne, Werner W. and Friedrich Schneider. 1978. "Fiscal Illusion, Political Institutions and Local Public Spending," Kyklos 31:3, pp. 381-408.

Pommerehne, Werner W. and Hannelore WeckHannemann. 1996. "Tax Rates, Tax Administration and Income Tax Evasion in Switzerland," Public Choice 88:1-2, pp. 161-70.

Ravallion, Martin and Michael Lokshin. 2001. "Identifying Welfare Effects from Subjective Questions," Economica 68:271, pp. 335-57.

Robbins, Lionel C. 1932. An Essay on the Nature and Significance of Economic Science. London: MacMillan. Selections reprinted in The Philosophy of Economics: An Anthology. Daniel M. Hausman, ed. 1984. NY: Cambridge U. Press.

Ruhm, Christopher J. 2000. "Are Recessions Good for Your Health?” Quart. J. Econ. 115:2, pp. 617-50.

Ryan, Richard M. and Edward L. Deci. 2001. "To Be Happy or To Be Self-Fulfilled: A Review of 
Research on Hedonic and Eudaimonic WellBeing," Ann. Rev. Psych. 52, pp. 141-66.

Sandvik, Ed; Ed Diener and Larry Seidlitz. 1993. "Subjective Well-Being: The Convergence and Stability of Self-Report and Non-Self-Report Measures,"J. Personality 61:3, pp. 317-42.

Santerre, Rexford E. 1986. "Representative versus Direct Democracy: A Tiebout Test of Relative Performance," Public Choice 48:1, pp. 55-63. 1989. "Representative versus Direct Democracy: Are There Any Expenditure Differences?" Public Choice 60:2, pp. 145-54.

Schwarz, Norbert and Fritz Strack. 1999. "Reports of Subjective Well-Being: Judgmental Processes and Their Methodological Implications," in Kahneman, Diener and Schwarz, op. cit., pp. 61-84.

Scitovsky, Tibor. 1976. The Joyless Economy: An Inquiry into Human Satisfaction and Dissatisfaction. Oxford: Oxford U. Press.

Sen, Amartya K. 1986. "The Standard of Living," in Tanner Lectures on Human Values, Vol. VII. Sterling McMurrin, ed. Cambridge, UK: Cambridge U. Press.

1995. "Rationality and Social Choice," Amer. Econ. Rev. 85:1, pp. 1-24.

1997. "Maximization and the Act of Choice," Econometrica 65:4, pp. 745-779.

Shiller, Robert J. 1997. "Why Do People Dislike Inflation?" in Reducing Inflation: Motivation and Strategy. Christina D. Romer and David H. Romer, eds. Chicago and London: U. Chicago Press, pp. 13-65.

Sirgy, Joseph M. 1997. "Materialism and Quality of Life," Soc. Indicators Res. 43:3, pp. 22760.

Slesnick, Daniel T. 1998. "Empirical Approaches to the Measurement of Welfare," J. Econ. Lit. 36:4, pp. 2108-65.

Smith, Richard H.; Ed Diener and Douglas H. Wedell. 1989. "Intrapersonal and Social Comparison Determinants of Happiness: A RangeFrequency Analysis," J. Personality Social. Psych. 56:3, pp. 317-25.

Smith, Stephen and Peter Razzell. 1975. The Pools Winners. London: Caliban Books.

Sousa-Poza, Alfonso and Andrés A. Sousa-Poza. 2000. "Taking Another Look at the Gender/ Job-Satisfaction Paradox," Kyklos 53:2, pp. 13552.

Strack, Fritz; Michael Argyle and Norbert Schwarz, eds. 1991. Subjective Well-Being: An Interdisciplinary Perspective. Oxford: Pergamon Press.

Stutzer, Alois and Rafael Lalive. 2001. "The Role of Social Work Norms in Job Searching and Subjective Well-Being," Institute for Empirical Research in Econ., U. Zurich, work. paper 51.

Thaler, Richard H. 1992. The Winner's Curse.
Paradoxes and Anomalies of Economic Life. NY: Free Press.

Theil, Henry. 1964. Optimal Decision Rules for Government and Industry. Amsterdam: North Holland.

-Tiebout, Charles M. 1956. "A Pure Theory of Local Expenditure,” J. Polit. Econ. 64:5, pp. 41624.

Tinbergen, Jan. 1956. Economic Policy: Principles and Design. Amsterdam: North Holland.

Tversky, Amos and Dale Griffin. 1991. "Endowment and Contrast in Judgments of WellBeing," in Strategy and Choice. Richard J. Zeckhauser, ed. Cambridge and London: MIT Press, pp. 297-318.

van de Stadt, Huib; Arie Kapteyn and Sara van de Geer. 1985. “The Relativity of Utility: Evidence from Panel Data," Rev. Econ. Statist. 67:2, pp. 179-87.

van Herwaarden, Floor; Arie Kapteyn, and Bernard M. S. van Praag. 1977. "Twelve Thousand Individual Welfare Functions of Income: A Comparison of Six Samples in Belgium and The Netherlands," Europ. Econ. Rev. 9:3, pp. 283300.

van Praag, Bernard M. S. 1991. "Ordinal and Cardinal Utility. An Integration of the Two Dimensions of the Welfare Concept," J. Econometrics 50, pp. 69-89.

1993. "The Relativity of the Welfare Concept," in The Quality of Life. Martha Nussbaum and Amartya Sen, eds. Oxford: Clarendon, pp. 362-416.

van Praag, Bernard M. S. and Paul Frijters. 1999. "The Measurement of Welfare and Well-Being: The Leyden Approach," in Kahneman, Diener and Schwarz, op. cit., pp. 413-33.

van Praag, Bernard M. S. and Arie Kapteyn. 1973. "Further Evidence on the Individual Welfare Function of Income: An Empirical Investigation in the Netherlands," Europ. Econ. Rev. 4:1, pp. 33-62.

Veblen, Thorstein. 1899. The Theory of Leisure Class. NY: Modern Library.

Veenhoven, Ruut. 1993. Happiness in Nations: Subjective Appreciation of Life in 56 Nations 1946-1992. Rotterdam: Erasmus U. Press. 2000. "Freedom and Happiness: A Comparative Study in Forty-four Nations in the Early 1990s," in Culture and Subjective WellBeing. Ed Diener and Eunkook M. Suh, eds. Cambridge, MA: MIT Press, pp. 257-88.

Warr, Peter. 1999. "Well-Being and the Workplace," in Kahneman, Diener, and Schwarz, op. cit., pp. 392-412.

Winkelmann, Liliana and Rainer Winkelmann. 1998. "Why Are the Unemployed So Unhappy? Evidence from Panel Data," Economica 65:257, pp. $1-15$. 


\section{This article has been cited by:}

1. Julia M. Puaschunder. Socio-Psychological Motives of Socially Responsible Investors 209-247. [Crossref]

2. Edgardo Ayala, David Flores, Claudia Quintanilla, Raquel Castaño. 2017. Daily use of time, personal characteristics and experienced well-being. Journal of Consumer Marketing 34:2, 96-107. [Crossref]

3. Pablo Brañas-Garza, Ismael Rodríguez-Lara, Angel Sánchez. 2017. Humans expect generosity. Scientific Reports 7, 42446. [Crossref]

4. Bernadette Huyer-May, Claudia Schmiedeberg, Nina Schumann. 2017. Neighborhood Effects on Children's Subjective Deprivation: Are Poor Children's Perceptions of the Economic Situation in their Home Influenced by their Neighborhood?. Cbild Indicators Research . [Crossref]

5. Brendan Markey-Towler. 2017. I, Roboticus Oeconomicus The philosophy of mind in economics, and why it matters. Cambridge Journal of Economics 41:1, 203-237. [Crossref]

6. Lindsey Jones, Thomas Tanner. 2017. 'Subjective resilience': using perceptions to quantify household resilience to climate extremes and disasters. Regional Environmental Change 17:1, 229-243. [Crossref]

7. Liane Hentschke, Alexandra Kibbe, Siegmar Otto. Geld in der Psychologie: Vom Homo oeconomicus zum Homo sufficiensis 97-117. [Crossref]

8. Oznur Ozdamar. 2016. Exposure to air pollution and crime in the neighbourhood. International Journal of Social Economics 43:12, 1233-1253. [Crossref]

9. Daniel Osberghaus, Jan Kühling. 2016. Direct and indirect effects of weather experiences on life satisfaction - which role for climate change expectations?. Journal of Environmental Planning and Management 59:12, 2198-2230. [Crossref]

10. Philippe Aghion, Ufuk Akcigit, Angus Deaton, Alexandra Roulet. 2016. Creative Destruction and Subjective Well-Being. American Economic Review 106:12, 3869-3897. [Abstract] [View PDF article] [PDF with links]

11. Xiaojun Yang, Ping Qin, Jintao Xu. 2016. Positional concern, gender, and household expenditures: a case study in Yunnan province. China Agricultural Economic Review 8:4, 572-594. [Crossref]

12. Roberto Zotti, Nino Speziale, Cristian Barra. 2016. On the causal effect of religiosity on life satisfaction using a propensity score matching technique. International Journal of Social Economics 43:10, 1031-1048. [Crossref]

13. Alex Bryson, Michael White. 2016. Not so dissatisfied after all? The impact of union coverage on job satisfaction. Oxford Economic Papers 68:4, 898-919. [Crossref]

14. André van Hoorn, Esther-Mirjam Sent. 2016. Consumer Capital as the Source of Happiness: The Missing Economic Theory Underlying the Income-Happiness Paradox. Journal of Economic Issues 50:4, 984-1002. [Crossref]

15. Christopher Ambrey, Jennifer Ulichny, Christopher Fleming. 2016. The Social Connectedness and Life Satisfaction Nexus: A Panel Data Analysis of Women in Australia. Feminist Economics 1-32. [Crossref]

16. Sunhae Sul, Jennifer Kim, Incheol Choi. 2016. Subjective well-being, social buffering and hedonic editing in the quotidian. Cognition and Emotion 30:6, 1063-1080. [Crossref] 
17. Maria del Mar Salinas-Jiménez, Joaquín Artés, Javier Salinas-Jiménez. 2016. Educational mismatch and job aspirations. International Journal of Manpower 37:1, 115-134. [Crossref]

18. Dimitrios Nikolaou. 2015. Maternal Life Satisfaction, Marital Status, and Child Skill Formation. Eastern Economic Journal . [Crossref]

19. Scott E. Sampson. 2015. Value Paradoxes and the Time Value of Value. Service Science 7:3, 149-162. [Crossref]

20. Jeroen van den Bergh. Safe Climate Policy is Affordable: 12 Reasons 299-358. [Crossref]

21. Axel Ockenfels, Dirk Sliwka, Peter Werner. 2015. Bonus Payments and Reference Point Violations. Management Science 61:7, 1496-1513. [Crossref]

22. Martin Guzi, Pablo de Pedraza García. 2015. A web survey analysis of subjective well-being. International Journal of Manpower 36:1, 48-67. [Crossref]

23. Aviral Kumar Tiwari, Mihai Mutascu. 2015. The relationship between environmental degradation and happiness in 23 developed contemporary economies. Management of Environmental Quality: An International Journal 26:2, 301-321. [Crossref]

24. Bruce Headey,, Ruud Muffels. 2015. People Typically Experience Extended Periods of Relative Happiness or Unhappiness due to Positive Feedback Loops Between LS and Variables Which are Both Causes and Consequences of LS. Schmollers Jabrbuch 135:1, 97-108. [Crossref]

25. Pungpond Rukumnuaykit. 2015. Urbanisation, Poverty and Subjective Well-Being: Empirical Evidence from Thailand. Urban Policy and Research 33:1, 98-118. [Crossref]

26. Hande Inanc. 2015. Unemployment and the timing of parenthood. Demograpbic Research 32, 219-250. [Crossref]

27. Fabio Maccheroni, Massimo Marinacci, Aldo Rustichini. 2014. Pride and Diversity in Social Economies. American Economic Journal: Microeconomics 6:4, 237-271. [Abstract] [View PDF article] [PDF with links]

28. Rajan Nataraajan, Madhukar G. Angur. 2014. Innovative ability and entrepreneurial activity: two factors to enhance "quality of life". Journal of Business \& Industrial Marketing 29:6, 469-475. [Crossref]

29. Philipp Doerrenberg, Andreas Peichl. 2014. The impact of redistributive policies on inequality in OECD countries. Applied Economics 46:17, 2066-2086. [Crossref]

30. Jessie P.H. Poon, Qingyang Shang. 2014. Are creative workers happier in Chinese cities? The influence of work, lifestyle, and amenities on urban well-being. Urban Geograpby 35:4, 567-585. [Crossref]

31. Gareth.D. Leeves, Ric. Herbert. 2014. Gender differences in social capital investment: Theory and evidence. Economic Modelling 37, 377-385. [Crossref]

32. Vladimir Otrachshenko, Olga Popova. 2014. Life (dis)satisfaction and the intention to migrate: Evidence from Central and Eastern Europe. The Journal of Socio-Economics 48, 40-49. [Crossref]

33. Khadija Shams. 2014. Determinants of Subjective Well-Being and Poverty in Rural Pakistan: A MicroLevel Study. Social Indicators Research . [Crossref]

34. Song Gao, Xiangyi Meng, Li Zhang. 2014. Fiscal Decentralization and Life Satisfaction: Evidence from Urban China. Social Indicators Research . [Crossref]

35. Yongwei Chen, Tao Li, Yupeng Shi, Yilun Zhou. 2014. Welfare Costs of Inflation: Evidence from China. Social Indicators Research . [Crossref] 
36. Ramzi Mabsout. 2014. Bringing Ethics Back to Welfare Economics. Review of Social Economy 72:1, 1-27. [Crossref]

37. Anders Hayden. 2014. Enough of that already: sufficiency-based challenges to high-carbon consumption in Canada. Environmental Politics 23:1, 97-114. [Crossref]

38. Alin I. Florea, Steven B. Caudill. 2014. Happiness, religion and economic transition. Economics of Transition 22:1, 1-12. [Crossref]

39. Raymond M. Montizaan, Maarten C.M. Vendrik. 2014. Misery Loves Company: Exogenous shocks in retirement expectations and social comparison effects on subjective well-being. Journal of Economic Bebavior \& Organization 97, 1-26. [Crossref]

40. C. Sá, A. Martins, C. Gomes. 2014. Tax morale, Occupation and Income Level: An Analysis of Portuguese Taxpayers. Journal of Economics, Business and Management 112-116. [Crossref]

41. Joaquín Artés, Maria del Mar Salinas-Jiménez, Javier Salinas-Jiménez. 2013. Small Fish in a Big Pond or Big Fish in a Small Pond? The Effects of Educational Mismatch on Subjective Wellbeing. Social Indicators Research . [Crossref]

42. Y. H. Farzin, K. I. Akao. 2013. Poverty, social preference for employment, and natural resource depletion. Environmental Economics and Policy Studies . [Crossref]

43. Tess Bogaerts, Mario Pandelaere. 2013. Less is more: Why some domains are more positional than others. Journal of Economic Psychology 39, 225-236. [Crossref]

44. Silvia Garrido, Ildefonso Méndez, José-María Abellán. 2013. Analysing the Simultaneous Relationship Between Life Satisfaction and Health-Related Quality of Life. Journal of Happiness Studies 14:6, 1813-1838. [Crossref]

45. Elisabeth Hahn, Wendy Johnson, Frank M. Spinath. 2013. Beyond the heritability of life satisfaction The roles of personality and twin-specific influences. Journal of Research in Personality 47:6, 757-767. [Crossref]

46. Néstor Gandelman, Rubén Hernández-Murillo. 2013. What do happiness and health satisfaction data tell us about relative risk aversion?. Journal of Economic Psychology 39, 301-312. [Crossref]

47. Giuseppe Munda. 2013. BEYOND GDP: AN OVERVIEW OF MEASUREMENT ISSUES IN REDEFINING 'WEALTH'. Journal of Economic Surveys n/a-n/a. [Crossref]

48. Manfred Lenzen, Murukesan Krishnapillai, Deveraux Talagi, Jodie Quintal, Denise Quintal, Ron Grant, Simpson Abraham, Cindy Ehmes, Joy Murray. 2013. Cultural and socio-economic determinants of energy consumption on small remote islands. Natural Resources Forum n/a-n/a. [Crossref]

49. Annabelle Krause. 2013. Don't worry, be happy? Happiness and reemployment. Journal of Economic Bebavior \& Organization 96, 1-20. [Crossref]

50. Alexandra Cortés Aguilar, Teresa M. García Muñoz, Ana I. Moro-Egido. 2013. Heterogeneous selfemployment and satisfaction in Latin America. Journal of Economic Psychology 39, 44-61. [Crossref]

51. Eiji Yamamura. 2013. Trial experience, satisfaction and incentive to bring another lawsuit: Does aspiration level influence winners and losers?. Japan and the World Economy 28, 125-131. [Crossref]

52. Takashi Oshio, Maki Umeda, Mayu Fujii. 2013. The association of life satisfaction and self-rated health with income dynamics among male employees in Japan. Japan and the World Economy 28, 143-150. [Crossref] 
53. Christopher L. Ambrey, Christopher M. Fleming, Matthew Manning. 2013. Perception or Reality, What Matters Most When it Comes to Crime in Your Neighbourhood?. Social Indicators Research . [Crossref]

54. Tindara Addabbo, Maria Laura Di Tommaso, Anna Maccagnan. 2013. GENDER DIFFERENCES IN ITALIAN CHILDREN'S CAPABILITIES. Feminist Economics 1-32. [Crossref]

55. Renske J. Hoefman, Job Exel, Werner Brouwer. 2013. How to Include Informal Care in Economic Evaluations. PharmacoEconomics . [Crossref]

56. Marta Portela, Isabel Neira, Maria del Mar Salinas-Jiménez. 2013. Social Capital and Subjective Wellbeing in Europe: A New Approach on Social Capital. Social Indicators Research 114:2, 493-511. [Crossref]

57. Cristina Bernini, Andrea Guizzardi, Giovanni Angelini. 2013. DEA-Like Model and Common Weights Approach for the Construction of a Subjective Community Well-Being Indicator. Social Indicators Research 114:2, 405-424. [Crossref]

58. Andreas Knabe, Steffen Rätzel, Stephan L. Thomsen. 2013. Right-Wing Extremism and the WellBeing of Immigrants. Kyklos 66:4, 567-590. [Crossref]

59. Analia Olgiati, Rocio Calvo, Lisa Berkman. 2013. Are Migrants Going Up a Blind Alley? Economic Migration and Life Satisfaction around the World: Cross-National Evidence from Europe, North America and Australia. Social Indicators Research 114:2, 383-404. [Crossref]

60. Semih Tumen, Tugba Zeydanli. 2013. Day-of-the-Week Effects in Subjective Well-Being: Does Selectivity Matter?. Social Indicators Research . [Crossref]

61. Arie Sherman, Tal Shavit. 2013. The immaterial sustenance of work and leisure: A new look at the work-leisure model. The Journal of Socio-Economics 46, 10-16. [Crossref]

62. Bruno S. Frey, Jana Gallus. 2013. Political economy of happiness. Applied Economics 45:30, 4205-4211. [Crossref]

63. Daniel S. Hamermesh, Jason Abrevaya. 2013. "BEAUTY IS THE PROMISE OF HAPPINESS”?. European Economic Review . [Crossref]

64. Martin Rode. 2013. Do Good Institutions Make Citizens Happy, or Do Happy Citizens Build Better Institutions?. Journal of Happiness Studies 14:5, 1479-1505. [Crossref]

65. Bruno S. Frey, Jana Gallus. 2013. Subjective Well-Being and Policy. Topoi 32:2, 207-212. [Crossref]

66. Christoph Wunder, Guido Heineck. 2013. Working time preferences, hours mismatch and well-being of couples: Are there spillovers?. Labour Economics 24, 244-252. [Crossref]

67. Trine Bille, Cecilie Bryld Fjællegaard, Bruno S. Frey, Lasse Steiner. 2013. Happiness in the artsInternational evidence on artists' job satisfaction. Economics Letters 121:1, 15-18. [Crossref]

68. Thierry Pénard, Nicolas Poussing, Raphaël Suire. 2013. Does the Internet make people happier?. The Journal of Socio-Economics 46, 105-116. [Crossref]

69. CHRISTOPHER TSOUKIS, FRÉDÉRIC TOURNEMAINE. 2013. STATUS IN A CANONICAL MACRO MODEL: LABOUR SUPPLY, GROWTH AND INEQUALITY*. The Manchester School 81, 65-92. [Crossref]

70. D. Oesch, O. Lipps. 2013. Does Unemployment Hurt Less if There is More of it Around? A Panel Analysis of Life Satisfaction in Germany and Switzerland. European Sociological Review 29:5, 955-967. [Crossref] 
71. Giuseppe Munda. 2013. On the Use of Shadow Prices for Sustainable Well-Being Measurement. Social Indicators Research . [Crossref]

72. Marzieh Abolhassani, Rob Alessie. 2013. Subjective Well-Being Around Retirement. De Economist 161:3, 349-366. [Crossref]

73. Carmelo J. León, Jorge E. Araña, Javier de León. 2013. Valuing the social cost of corruption using subjective well being data and the technique of vignettes. Applied Economics 45:27, 3863-3870. [Crossref]

74. Ognjen Obućina. 2013. The Patterns of Satisfaction Among Immigrants in Germany. Social Indicators Research 113:3, 1105-1127. [Crossref]

75. Angela Kopmann, Katrin Rehdanz. 2013. A human well-being approach for assessing the value of natural land areas. Ecological Economics 93, 20-33. [Crossref]

76. Cristina Santos. 2013. Costs of Domestic Violence: A Life Satisfaction Approach*. Fiscal Studies 34:3, 391-409. [Crossref]

77. Abel Brodeur, Marie Connolly. 2013. Do higher child care subsidies improve parental well-being? Evidence from Quebec's family policies. Journal of Economic Bebavior \& Organization 93, 1-16. [Crossref]

78. Christoph Wunder, Johannes Schwarze. 2013. Is Posner Right? An Empirical Test of the Posner Argument for Transferring Health Spending from Old Women to Old Men. Journal of Happiness Studies . [Crossref]

79. Robert Rudolf. 2013. Work Shorter, Be Happier? Longitudinal Evidence from the Korean Five-Day Working Policy. Journal of Happiness Studies . [Crossref]

80. Bruno S. Frey, Alois Stutzer. 2013. Economic Consequences of Mispredicting Utility. Journal of Happiness Studies . [Crossref]

81. Marc Fleurbaey, Erik Schokkaert. 2013. Behavioral Welfare Economics and Redistribution. American Economic Journal: Microeconomics 5:3, 180-205. [Abstract] [View PDF article] [PDF with links]

82. Roberson Édouard, Gérard Duhaime. 2013. The Well-Being of the Canadian Arctic Inuit: The Relevant Weight of Economy in the Happiness Equations. Social Indicators Research 113:1, 373-392. [Crossref]

83. Emanuele Blasi, Maria Nucera, Clara Cicatiello, Silvio Franco. 2013. Socio-demographic Components of Eudaimonic Well-Being: A Survey in an Italian Province. Social Indicators Research 113:1, 451-470. [Crossref]

84. Erich Gundlach, Matthias Opfinger. 2013. Religiosity as a Determinant of Happiness. Review of Development Economics 17:3, 523-539. [Crossref]

85. Bokim Lee. 2013. Job and Life Satisfaction of Nonstandard Workers in South Korea. Workplace Health \& Safety 61:8, 355-363. [Crossref]

86. John P. Barile, Bryce B. Reeve, Ashley Wilder Smith, Matthew M. Zack, Sandra A. Mitchell, Rosemarie Kobau, David F. Cella, Cecily Luncheon, William W. Thompson. 2013. Monitoring population health for Healthy People 2020: evaluation of the NIH PROMIS ${ }^{\circledR}$ Global Health, CDC Healthy Days, and satisfaction with life instruments. Quality of Life Research 22:6, 1201-1211. [Crossref]

87. Chu-Chia Lin, Tsung-Chi Cheng, Shu-Chen Wang. 2013. Measuring Subjective Well-Being in Taiwan. Social Indicators Research . [Crossref] 
88. Krzysztof Zagorski, Mariah D. R. Evans, Jonathan Kelley, Katarzyna Piotrowska. 2013. Does National Income Inequality Affect Individuals' Quality of Life in Europe? Inequality, Happiness, Finances, and Health. Social Indicators Research . [Crossref]

89. Alpaslan Akay, Corrado Giulietti, Juan D. Robalino, Klaus F. Zimmermann. 2013. Remittances and well-being among rural-to-urban migrants in China. Review of Economics of the Housebold . [Crossref]

90. André van Hoorn, Robbert Maseland. 2013. Does a Protestant work ethic exist? Evidence from the well-being effect of unemployment. Journal of Economic Behavior \& Organization 91, 1-12. [Crossref]

91. Bruce Headey, Ruud Muffels, Gert G. Wagner. 2013. Choices Which Change Life Satisfaction: Similar Results for Australia, Britain and Germany. Social Indicators Research 112:3, 725-748. [Crossref]

92. Juncal Cuñado, Fernando Pérez Gracia. 2013. Environment and Happiness: New Evidence for Spain. Social Indicators Research 112:3, 549-567. [Crossref]

93. Rune Elvik. 2013. Paradoxes of rationality in road safety policy. Research in Transportation Economics 43:1, 62-70. [Crossref]

94. Christo Pirinsky. 2013. Confidence and economic attitudes. Journal of Economic Bebavior \& Organization 91, 139-158. [Crossref]

95. Pei-Chun Lin, Zhou-Hern Lin. 2013. Buying impulse triggered by digital media. The Service Industries Journal 33:9-10, 892-908. [Crossref]

96. Lorna Zischka. 2013. VALUING SOCIAL CAPITAL BY THE RESOURCES PEOPLE ALLOCATE TO ONE ANOTHER. Journal of International Development 25:5, 609-625. [Crossref]

97. Cahit Guven, Rudy Saloumidis. 2013. Life Satisfaction and Longevity: Longitudinal Evidence from the German Socio-Economic Panel. German Economic Review n/a-n/a. [Crossref]

98. Emma Iglesias Vázquez, José Atilano Pena López, José Manuel Sánchez Santos. 2013. Bienestar subjetivo, renta y bienes relacionales. Los determinantes de la felicidad en España. Revista Internacional de Sociología, ahead of print. [Crossref]

99. Daniele Vignoli, Elena Pirani, Silvana Salvini. 2013. Family Constellations and Life Satisfaction in Europe. Social Indicators Research . [Crossref]

100. Lewis Davis, Stephen Wu. 2013. Social Comparisons and Life Satisfaction Across Racial and Ethnic Groups: The Effects of Status, Information and Solidarity. Social Indicators Research . [Crossref]

101. Eszter Siposne Nandori. 2013. Interpretation of Poverty in St. Louis County, Minnesota. Applied Research in Quality of Life . [Crossref]

102. Viola Angelini, Danilo Cavapozzi, Luca Corazzini, Omar Paccagnella. 2013. Do Danes and Italians Rate Life Satisfaction in the Same Way? Using Vignettes to Correct for Individual-Specific Scale Biases. Oxford Bulletin of Economics and Statistics n/a-n/a. [Crossref]

103. Michael Mutz, Sylvia Kämpfer. 2013. Emotionen und Lebenszufriedenheit in der „Erlebnisgesellschaft“. KZfSS Kölner Zeitschrift für Soziologie und Sozialpsychologie 65:2, 253-275. [Crossref]

104. Amina Ebrahim, Ferdi Botha, Jen Snowball. 2013. Determinants of life satisfaction among race groups in South Africa. Development Southern Africa 30:2, 168-185. [Crossref]

105. Leonardo Becchetti, Alessandra Pelloni. 2013. What are we learning from the life satisfaction literature?. International Review of Economics 60:2, 113-155. [Crossref] 
106. Manfred Lenzen, Robert Cummins. 2013. Happiness versus the Environment-A Case Study of Australian Lifestyles. Challenges 4:1, 56-74. [Crossref]

107. Takashi Oshio, Maki Umeda, Norito Kawakami. 2013. Childhood Adversity and Adulthood Subjective Well-Being: Evidence from Japan. Journal of Happiness Studies 14:3, 843-860. [Crossref]

108. Maria C. Pereira, Filipe Coelho. 2013. Untangling the Relationship Between Income and Subjective Well-Being: The Role of Perceived Income Adequacy and Borrowing Constraints. Journal of Happiness Studies 14:3, 985-1005. [Crossref]

109. KITAE SOHN. 2013. SOURCES OF HAPPINESS IN INDONESIA. The Singapore Economic Review 1350014. [Crossref]

110. Xiaojun Yang, Jintao Xu. 2013. Program sustainability and the determinants of farmers' self-predicted post-program land use decisions: evidence from the Sloping Land Conversion Program (SLCP) in China. Environment and Development Economics 1-18. [Crossref]

111. Betsey Stevenson,, Justin Wolfers. 2013. Subjective Well-Being and Income: Is There Any Evidence of Satiation?. American Economic Review 103:3, 598-604. [Abstract] [View PDF article] [PDF with links]

112. Colin P. Green, Gareth D. Leeves. 2013. Job Security, Financial Security and Worker Well-being: New Evidence on the Effects of Flexible Employment. Scottish Journal of Political Economy 60:2, 121-138. [Crossref]

113. Timothy Tyler Brown. 2013. A monetary valuation of individual religious behaviour: the case of prayer. Applied Economics 45:15, 2031-2037. [Crossref]

114. Martin Binder, Felix Ward. 2013. The Structure of Subjective Well-being: A Vector Autoregressive Approach. Metroeconomica 64:2, 361-400. [Crossref]

115. Jan Urban, Vojtěch Máca. 2013. Linking Traffic Noise, Noise Annoyance and Life Satisfaction: A Case Study. International Journal of Environmental Research and Public Health 10:5, 1895-1915. [Crossref]

116. Victoria Ateca-Amestoy, Alexandra Cortés Aguilar, Ana I. Moro-Egido. 2013. Social Interactions and Life Satisfaction: Evidence from Latin America. Journal of Happiness Studies . [Crossref]

117. Bruce Headey, Ruud Muffels, Gert G. Wagner. 2013. Parents Transmit Happiness Along with Associated Values and Behaviors to Their Children: A Lifelong Happiness Dividend?. Social Indicators Research . [Crossref]

118. Emmanouil Mentzakis, Marc Suhrcke, Bayard Roberts, Adrianna Murphy, Martin McKee. 2013. Estimating the causal effect of alcohol consumption on well-being for a cross-section of 9 former Soviet Union countries. Social Science \& Medicine . [Crossref]

119. Mariana Gerstenblüth, Máximo Rossi. 2013. Are healthier people happier? Evidence from Chile and Uruguay. Development in Practice 23:2, 205-216. [Crossref]

120. Alfredo R. Paloyo. 2013. Co-Pay and Feel Okay: Self-Rated Health Status After a Health Insurance Reform. Social Science Quarterly n/a-n/a. [Crossref]

121. Martin Binder. 2013. Innovativeness and Subjective Well-Being. Social Indicators Research 111:2, 561-578. [Crossref]

122. Marie Connolly. 2013. Some Like It Mild and Not Too Wet: The Influence of Weather on Subjective Well-Being. Journal of Happiness Studies 14:2, 457-473. [Crossref] 
123. Arno Tausch, Almas Heshmati. 2013. Worker remittances and the global preconditions of 'smart development'. Society and Economy 35:1, 25-50. [Crossref]

124. Alon Raviv, Elif Sisli-Ciamarra. 2013. Executive compensation, risk taking and the state of the economy. Journal of Financial Stability 9:1, 55-68. [Crossref]

125. Martin Halla, Friedrich G. Schneider, Alexander F. Wagner. 2013. Satisfaction with democracy and collective action problems: the case of the environment. Public Choice 155:1-2, 109-137. [Crossref]

126. Chun-Hung A. Lin, Suchandra Lahiri, Ching-Po Hsu. 2013. Happiness and Regional Segmentation: Does Space Matter?. Journal of Happiness Studies . [Crossref]

127. Kit-Chun Joanna Lam, Pak-Wai Liu. 2013. Socio-Economic Inequalities in Happiness in China and U.S. Social Indicators Research . [Crossref]

128. Roma Mitra Debnath, Ravi Shankar. 2013. Does Good Governance Enhance Happiness: A Cross Nation Study. Social Indicators Research . [Crossref]

129. Stephan Humpert, Christian Pfeifer. 2013. Explaining age and gender differences in employment rates: a labor supply-side perspective. Journal for Labour Market Research 46:1, 1-17. [Crossref]

130. Oliver K. Schilling, Hans-Werner Wahl, Frank Oswald. 2013. Change in Life Satisfaction Under Chronic Physical Multi-morbidity in Advanced Old Age: Potential and Limits of Adaptation. Journal of Happiness Studies 14:1, 19-36. [Crossref]

131. Ilka H. Gleibs, Thomas A. Morton, Anna Rabinovich, S. Alexander Haslam, John F. Helliwell. 2013. Unpacking the hedonic paradox: A dynamic analysis of the relationships between financial capital, social capital and life satisfaction. British Journal of Social Psychology 52:1, 25-43. [Crossref]

132. Néstor Gandelman, Giorgina Piani. 2013. Quality of Life Satisfaction among Workers and NonWorkers in Uruguay. Social Indicators Research 111:1, 97-115. [Crossref]

133. Edsel L. Beja. 2013. Subjective Well-Being Approach to the Valuation of International Development: Evidence for the Millennium Development Goals. Social Indicators Research 111:1, 141-159. [Crossref]

134. R. Schob. 2013. Unemployment and Identity. CESifo Economic Studies 59:1, 149-180. [Crossref]

135. Frederick J. Zimmerman. 2013. Habit, custom, and power: A multi-level theory of population health. Social Science \& Medicine 80, 47-56. [Crossref]

136. Kitae Sohn. 2013. Monetary and Nonmonetary Returns to Education in Indonesia. The Developing Economies 51:1, 34-59. [Crossref]

137. Leonardo Becchetti, Pierluigi Conzo. 2013. Credit access and life satisfaction: evaluating the nonmonetary effects of micro finance. Applied Economics 45:9, 1201-1217. [Crossref]

138. Patti Collett Miles, Grant Miles. 2013. Corporate social responsibility and executive compensation: exploring the link. Social Responsibility Journal 9:1, 76-90. [Crossref]

139. Alexandra Nonnenmacher, Jürgen Friedrichs. 2013. The Missing Link: Deficits of Country-Level Studies. A Review of 22 Articles Explaining Life Satisfaction. Social Indicators Research 110:3, 1221-1244. [Crossref]

140. Carlo Klein. 2013. Social Capital or Social Cohesion: What Matters For Subjective Well-Being?. Social Indicators Research 110:3, 891-911. [Crossref]

141. Feng Hu. 2013. Homeownership and Subjective Wellbeing in Urban China: Does Owning a House Make You Happier?. Social Indicators Research 110:3, 951-971. [Crossref] 
142. Konstantinos Pouliakas, Ioannis Theodossiou. 2013. THE ECONOMICS OF HEALTH AND SAFETY AT WORK: AN INTERDICIPLINARY REVIEW OF THE THEORY AND POLICY. Journal of Economic Surveys 27:1, 167-208. [Crossref]

143. Hung-Lin Tao, Shih-Yung Chiu. 2013. Income growth, redistribution, and subjective well-being in Taiwan - a simulation study. Applied Economics 45:6, 775-791. [Crossref]

144. N. Valkila, A. Saari. 2013. Attitude-behaviour gap in energy issues: Case study of three different Finnish residential areas. Energy for Sustainable Development 17:1, 24-34. [Crossref]

145. Stefano Bartolini, Ennio Bilancini, Maurizio Pugno. 2013. Did the Decline in Social Connections Depress Americans' Happiness?. Social Indicators Research 110:3, 1033-1059. [Crossref]

146. Christopher L. Ambrey, Christopher M. Fleming. 2013. Life Satisfaction in Australia: Evidence from Ten Years of the HILDA Survey. Social Indicators Research . [Crossref]

147. Yoshiro Tsutsui. 2013. Weather and Individual Happiness. Weather, Climate, and Society 5:1, 70-82. [Crossref]

148. Jorge Guardiola, Francisco González-Gómez, Miguel A. García-Rubio, Ángel Lendechy-Grajales. 2013. Does higher income equal higher levels of happiness in every society? The case of the Mayan people. International Journal of Social Welfare 22:1, 35-44. [Crossref]

149. Rachel Margolis, Mikko Myrskylä. 2013. Family, money, and health: Regional differences in the determinants of life satisfaction over the life course. Advances in Life Course Research . [Crossref]

150. Eva M. Berger. 2013. Happy Working Mothers? Investigating the Effect of Maternal Employment on Life Satisfaction. Economica 80:317, 23-43. [Crossref]

151. Siddhartha Mitra. 2013. Utility Maximisation as a Pathway for Maximisation of Happiness. Interdisciplinary Description of Complex Systems 11:3, 302-309. [Crossref]

152. L. Becchetti, R. Massari, P. Naticchioni. 2013. The drivers of happiness inequality: suggestions for promoting social cohesion. Oxford Economic Papers . [Crossref]

153. Amy Finkelstein, Erzo F. P. Luttmer, Matthew J. Notowidigdo. 2013. WHAT GOOD IS WEALTH WITHOUT HEALTH? THE EFFECT OF HEALTH ON THE MARGINAL UTILITY OF CONSUMPTION. Journal of the European Economic Association 11, 221-258. [Crossref]

154. Chris M. Herbst. 2013. Welfare reform and the subjective well-being of single mothers. Journal of Population Economics 26:1, 203-238. [Crossref]

155. Aline Bütikofer. 2013. Revisiting 'mothers and sons' preference formation and the female labor force in Switzerland. Labour Economics 20, 82-91. [Crossref]

156. Peter H. van der Meer, Rudi Wielers. 2013. What makes workers happy?. Applied Economics 45:3, 357-368. [Crossref]

157. Namrata Chindarkar. 2012. Is Subjective Well-Being of Concern to Potential Migrants from Latin America?. Social Indicators Research . [Crossref]

158. Devrim Dumludag. 2012. Life Satisfaction and Income Comparison Effects in Turkey. Social Indicators Research . [Crossref]

159. Denise Brown, Julie Woolf, Conal Smith. 2012. An empirical investigation into the determinants of life satisfaction in New Zealand. New Zealand Economic Papers 46:3, 239-251. [Crossref]

160. Zhiqiang Liu, Qingyan Shang. 2012. Individual well-being in urban China: The role of income expectations. China Economic Review 23:4, 833-849. [Crossref] 
161. Sigit D. Arifwidodo. 2012. Exploring the effect of compact development policy to urban quality of life in Bandung, Indonesia. City, Culture and Society 3:4, 303-311. [Crossref]

162. Bruno S. Frey. 2012. Well-being and war. International Review of Economics 59:4, 363-375. [Crossref]

163. Joaquín Gómez-Miñambres. 2012. Motivation through goal setting. Journal of Economic Psychology 33:6, 1223-1239. [Crossref]

164. Bruno S. Frey, Lasse Steiner. 2012. Glücksforschung: Eine empirische Analyse. AStA Wirtschafts- und Sozialstatistisches Archiv 6:1-2, 9-25. [Crossref]

165. Cahit Guven, Bent E. Sørensen. 2012. Subjective Well-Being: Keeping Up with the Perception of the Joneses. Social Indicators Research 109:3, 439-469. [Crossref]

166. Christopher L. Ambrey, Christopher M. Fleming. 2012. Valuing Australia's protected areas: A life satisfaction approach. New Zealand Economic Papers 46:3, 191-209. [Crossref]

167. STAVROS A. DRAKOPOULOS. 2012. THE HISTORY OF ATTITUDES TOWARDS INTERDEPENDENT PREFERENCES. Journal of the History of Economic Thought 34:04, 541-557. [Crossref]

168. Alfred M. Dockery. 2012. Deriving the labour supply curve from happiness data. Economics Letters 117:3, 898-900. [Crossref]

169. Timothy Hinks. 2012. Fractionalization and well-being: Evidence from a new South African data set. New Zealand Economic Papers 46:3, 253-271. [Crossref]

170. Gintautas Bloze, Morten Skak. 2012. Housing Tenure and Psychological Distress. International Journal of Housing Policy 12:4, 471-488. [Crossref]

171. Christopher L. Ambrey, Christopher M. Fleming. 2012. Valuing Ecosystem Diversity in South East Queensland: A Life Satisfaction Approach. Social Indicators Research . [Crossref]

172. Peter H. Meer. 2012. Gender, Unemployment and Subjective Well-Being: Why Being Unemployed Is Worse for Men than for Women. Social Indicators Research . [Crossref]

173. ARIE SHERMAN, TAL SHAVIT. 2012. How the lifecycle hypothesis explains volunteering during retirement. Ageing and Society 32:08, 1360-1381. [Crossref]

174. Ennio Bilancini, Massimo D’Antoni. 2012. The desirability of pay-as-you-go pensions when relative consumption matters and returns are stochastic. Economics Letters 117:2, 418-422. [Crossref]

175. Gilles Grolleau, Igor Galochkin, Angela Sutan. 2012. Escaping the Zero-Sum Game of Positional Races. Kyklos 65:4, 464-479. [Crossref]

176. David Card, Alexandre Mas,, Enrico Moretti,, Emmanuel Saez. 2012. Inequality at Work: The Effect of Peer Salaries on Job Satisfaction. American Economic Review 102:6, 2981-3003. [Abstract] [View PDF article] [PDF with links]

177. Bent Greve. 2012. The impact of the financial crisis on happiness in affluent European countries. Journal of Comparative Social Welfare 28:3, 183-193. [Crossref]

178. Paul Frijters, David W. Johnston, Michael A. Shields. 2012. The Optimality of Tax Transfers: What does Life Satisfaction Data Tell Us?. Journal of Happiness Studies 13:5, 821-832. [Crossref]

179. F. Maccheroni, M. Marinacci, A. Rustichini. 2012. Social Decision Theory: Choosing within and between Groups. The Review of Economic Studies 79:4, 1591-1636. [Crossref]

180. KATIE WRIGHT. 2012. Constructing human wellbeing across spatial boundaries: negotiating meanings in transnational migration. Global Networks 12:4, 467-484. [Crossref] 
181. Salvatore Bimonte, Valeria Faralla. 2012. Tourist types and happiness a comparative study in Maremma, Italy. Annals of Tourism Research 39:4, 1929-1950. [Crossref]

182. Casey Boyd-Swan, Chris M. Herbst. 2012. Pain at the pump: Gasoline prices and subjective wellbeing. Journal of Urban Economics 72:2-3, 160-175. [Crossref]

183. George MacKerron. 2012. HAPPINESS ECONOMICS FROM 35000 FEET. Journal of Economic Surveys 26:4, 705-735. [Crossref]

184. Leonardo Becchetti. 2012. Voting with the wallet. International Review of Economics 59:3, 245-268. [Crossref]

185. Haifang Huang, Brad R. Humphreys. 2012. Sports participation and happiness: Evidence from US microdata. Journal of Economic Psychology 33:4, 776-793. [Crossref]

186. Emmanouil Mentzakis, Paul McNamee, Mandy Ryan, Matthew Sutton. 2012. Valuing Informal Care Experience: Does Choice of Measure Matter?. Social Indicators Research 108:1, 169-184. [Crossref]

187. Cahit Guven. 2012. Reversing the question: Does happiness affect consumption and savings behavior?. Journal of Economic Psychology 33:4, 701-717. [Crossref]

188. Marc Keuschnigg, Tobias Wolbring. 2012. Reich und zufrieden? Theorie und Empirie zur Beziehung von Wohlstand und Lebenszufriedenheit. Berliner Journal für Soziologie 22:2, 189-216. [Crossref]

189. Keith A. Bender. 2012. An analysis of well-being in retirement: The role of pensions, health, and 'voluntariness' of retirement. The Journal of Socio-Economics 41:4, 424-433. [Crossref]

190. Timothy J. Bartik. 2012. Including Jobs in Benefit-Cost Analysis. Annual Review of Resource Economics 4:1, 55-73. [Crossref]

191. Jantine Voordouw, Gerrit Antonides, Margaret Fox, Inmaculada Cerecedo, Javier Zamora, Belen Hoz Caballer, Ewa Rokicka, Judith Cornelisse-Vermaat, Maciej Jewczak, Pawel Starosta, Marek L. Kowalska, Monika Jędrzejczak-Czechowicz, Sonia Vázquez-Cortés, Cano Escudero, Bertine Flokstra Blok, Anthony Dubois, Miranda Mugford, Lynn J. Frewer. 2012. Subjective Welfare, Well-Being, and Self-Reported Food Hypersensitivity in Four European Countries: Implications for European Policy. Social Indicators Research 107:3, 465-482. [Crossref]

192. Bruno S. Frey, Roger Lüthi, Margit Osterloh. 2012. Community Enterprises-An Institutional Innovation. Managerial and Decision Economics 33:5-6, 427-439. [Crossref]

193. MADHU S. MOHANTY, AMAN ULLAH. 2012. Why Does Growing up in an Intact Family during Childhood Lead to Higher Earnings during Adulthood in the United States?*. American Journal of Economics and Sociology 71:3, 662-695. [Crossref]

194. Zhonglu Zeng, David Forrest, Ian G. McHale. 2012. Happiness and Job Satisfaction in a CasinoDominated Economy. Journal of Gambling Studies . [Crossref]

195. Hung-Hao Chang. 2012. Does the use of eco-labels affect income distribution and income inequality of aquaculture producers in Taiwan?. Ecological Economics . [Crossref]

196. Christian Schubert. 2012. Pursuing Happiness. Kyklos 65:2, 245-261. [Crossref]

197. Ennio Bilancini, Leonardo Boncinelli. 2012. Redistribution and the Notion of Social Status. Journal of Public Economics . [Crossref]

198. Ariel R. Belasen, R.W. Hafer. 2012. Well-being and economic freedom: Evidence from the States. Intelligence 40:3, 306-316. [Crossref] 
199. Paul Frijters, Tony Beatton. 2012. The mystery of the U-shaped relationship between happiness and age. Journal of Economic Behavior \& Organization 82:2-3, 525-542. [Crossref]

200. Cahit Guven, Claudia Senik, Holger Stichnoth. 2012. You can't be happier than your wife. Happiness gaps and divorce. Journal of Economic Behavior \& Organization 82:1, 110-130. [Crossref]

201. Karsten Kohn, Katrin Ullrich. 2012. Die Mär vom Gründer im Glück - Gründungsentscheidung und subjektive Lebenszufriedenheit. ZfKE - Zeitschrift für KMU und Entrepreneurship 60:2, 137-161. [Crossref]

202. Madhu S. Mohanty, Aman Ullah. 2012. Direct and indirect effects of happiness on wage: A simultaneous equations approach. The Journal of Socio-Economics 41:2, 143-152. [Crossref]

203. John Knight, Ramani Gunatilaka. 2012. Income, aspirations and the Hedonic Treadmill in a poor society. Journal of Economic Behavior \& Organization 82:1, 67-81. [Crossref]

204. Richard Patterson, Joseph Price. 2012. Pornography, Religion, and the Happiness Gap: Does Pornography Impact the Actively Religious Differently?. Journal for the Scientific Study of Religion 51:1, 79-89. [Crossref]

205. Carola Gruen, Stephan Klasen. 2012. Has transition improved well-being?. Economic Systems 36:1, 11-30. [Crossref]

206. Jean-Gaël E. Collomb, Janaki R. Alavalapati, Tim Fik. 2012. Building a Multidimensional Wellbeing Index for Rural Populations in Northeastern Namibia. Journal of Human Development and Capabilities 1-20. [Crossref]

207. Juncal Cuñado, Fernando Pérez de Gracia. 2012. Does Media Consumption Make Us Happy? Evidence for Spain. Journal of Media Economics 25:1, 8-34. [Crossref]

208. Marta Orviska, Anetta Caplanova, John Hudson. 2012. The Impact of Democracy on Well-being. Social Indicators Research . [Crossref]

209. Alpaslan Akay, Olivier Bargain, Klaus F. Zimmermann. 2012. Relative concerns of rural-to-urban migrants in China. Journal of Economic Behavior \& Organization 81:2, 421-441. [Crossref]

210. Kathleen Beegle, Kristen Himelein, Martin Ravallion. 2012. Frame-of-reference bias in subjective welfare. Journal of Economic Behavior \& Organization 81:2, 556-570. [Crossref]

211. Bert Van Landeghem. 2012. A test for the convexity of human well-being over the life cycle: Longitudinal evidence from a 20-year panel. Journal of Economic Bebavior \& Organization 81:2, 571-582. [Crossref]

212. Paul H. Dembinski. 2012. The Incompleteness of the Economy and Business: A Forceful Reminder. Journal of Business Ethics. [Crossref]

213. Marc Keuschnigg, Eva Negele, Tobias Wolbring. 255-281. [Crossref]

214. Erik Angner, George Loewenstein. Behavioral Economics 641-689. [Crossref]

215. Cheryl J Carleton, Suzanne Heller Clain. 2012. Women, Men, and Job Satisfaction. Eastern Economic Journal 38:3, 331-355. [Crossref]

216. YOSHIRO TSUTSUI, FUMIO OHTAKE. 2012. ASKING ABOUT CHANGES IN HAPPINESS IN A DAILY WEB SURVEY AND ITS IMPLICATION FOR THE EASTERLIN PARADOX*. Japanese Economic Review no-no. [Crossref]

217. Penka Kovacheva, Xiaotong Niu. The Mental Cost of Pension Loss: The Experience of Russia's Pensioners during Transition 191-240. [Crossref] 
218. Riichiro Ishida. 2012. Purpose in Life (Ikigai), a Frontal Lobe Function, Is a Natural. Psychology 03:03, 272-276. [Crossref]

219. Bruno S. Frey, Alois Stutzer. 2011. The use of happiness research for public policy. Social Choice and Welfare . [Crossref]

220. Damiano Fiorillo. 2011. Volunteer work and domain satisfactions: evidence from Italy. International Journal of Social Economics 39:1/2, 97-124. [Crossref]

221. Ben McQuillin, Robert Sugden. 2011. Reconciling normative and behavioural economics: the problems to be solved. Social Choice and Welfare . [Crossref]

222. Xiaolin Wang, Xiaoyuan Shang, Liping Xu. 2011. Subjective Well-being Poverty of the Elderly Population in China. Social Policy \& Administration 45:6, 714-731. [Crossref]

223. Andrew Hodge, Alan Duhs. 2011. Implicit <i >a prioris</i > in the Evolution of Economics: Ratzinger's Alternative. Journal of Economic Issues 0:4, 941-964. [Crossref]

224. Judith Clifton, Daniel Díaz-Fuentes, Marcos Fernández-Gutiérrez, Julio Revuelta. 2011. IS MARKET-ORIENTED REFORM PRODUCING A 'TWO-TRACK' EUROPE? EVIDENCE FROM ELECTRICITY AND TELECOMMUNICATIONS. Annals of Public and Cooperative Economics 82:4, 495-513. [Crossref]

225. Christian Schubert. 2011. Is novelty always a good thing? Towards an evolutionary welfare economics. Journal of Evolutionary Economics. [Crossref]

226. Katie Wright. 2011. Constructing Migrant Wellbeing: An Exploration of Life Satisfaction Amongst Peruvian Migrants in London. Journal of Ethnic and Migration Studies 37:9, 1459-1475. [Crossref]

227. Paul Frijters, Amy Y.C. Liu, Xin Meng. 2011. Are optimistic expectations keeping the Chinese happy?. Journal of Economic Behavior \& Organization . [Crossref]

228. Jorge Guardiola, Teresa García-Muñoz. 2011. Fulfilment of basic needs from a subjective point of view in rural Guatemala. International Journal of Social Welfare 20:4, 393-403. [Crossref]

229. Lok Sang Ho. 2011. Hong Kong's happiness indices: What they tell us about LIFE?. The Journal of Socio-Economics 40:5, 564-572. [Crossref]

230. Axel v. Werder. 2011. Corporate Governance and Stakeholder Opportunism. Organization Science 22:5, 1345-1358. [Crossref]

231. Peder J. Pedersen, Torben Dall Schmidt. 2011. Happiness in Europe. The Journal of Socio-Economics 40:5, 480-489. [Crossref]

232. Christopher L. Ambrey, Christopher M. Fleming. 2011. Valuing scenic amenity using life satisfaction data. Ecological Economics . [Crossref]

233. Heinz Welsch, Jan Kühling. 2011. Are pro-environmental consumption choices utility-maximizing? Evidence from subjective well-being data. Ecological Economics . [Crossref]

234. Zohal Hessami. 2011. Globalization's winners and losers-Evidence from life satisfaction data, 19752001. Economics Letters 112:3, 250-253. [Crossref]

235. Philip S. Morrison. 2011. Local Expressions of Subjective Well-being: The New Zealand Experience. Regional Studies 45:8, 1039-1058. [Crossref]

236. Carsten Ochsen, Heinz Welsch. 2011. Who Benefits from Labor Market Institutions? Evidence from Surveys of Life Satisfaction. Journal of Economic Psychology . [Crossref] 
237. Markus Jokela, Liisa Keltikangas-Järvinen. 2011. The association between low socioeconomic status and depressive symptoms depends on temperament and personality traits. Personality and Individual Differences 51:3, 302-308. [Crossref]

238. Alpaslan Akay, Peter Martinsson, Haileselassie Medhin. 2011. Does Positional Concern Matter in Poor Societies? Evidence from a Survey Experiment in Rural Ethiopia. World Development . [Crossref]

239. Brian J. L. Berry, Adam Okulicz-Kozaryn. 2011. An Urban-Rural Happiness Gradient. Urban Geography 32:6, 871-883. [Crossref]

240. Stavros A. Drakopoulos. 2011. The neglect of comparison income: An historical perspective. The European Journal of the History of Economic Thought 18:3, 441-464. [Crossref]

241. Bruno S. Frey. 2011. Tullock challenges: happiness, revolutions, and democracy. Public Choice . [Crossref]

242. Christoph Wunder, Andrea Wiencierz, Johannes Schwarze, Helmut Küchenhoff. 2011. Well-Being over the Life Span: Semiparametric Evidence from British and German Longitudinal Data. Review of Economics and Statistics 110719103252002. [Crossref]

243. Chris M. Herbst. 2011. 'Paradoxical' Decline? Another Look at the Relative Reduction in Female Happiness. Journal of Economic Psychology . [Crossref]

244. Jennifer Roberts, Robert Hodgson, Paul Dolan. 2011. "It's driving her mad": Gender differences in the effects of commuting on psychological health. Journal of Health Economics . [Crossref]

245. Johannes Schwarze, Rainer Winkelmann. 2011. Happiness and altruism within the extended family. Journal of Population Economics 24:3, 1033-1051. [Crossref]

246. Naoko Yamada, Jinmoo Heo, Carina King, Yao-Yi Fu. 2011. Urban Residents' Life Satisfaction and Cultural Tourism Development: The Role of Health Perception, Wealth, Safety, Community Contentment, and Cultural Tourism Development. Journal of Quality Assurance in Hospitality \& Tourism 12:3, 220-235. [Crossref]

247. Ming-Chang Tsai, Heng-Hao Chang, Wan-chi Chen. 2011. Globally Happy: Individual Globalization, Expanded Capacities, and Subjective Wellbeing. Social Indicators Research . [Crossref]

248. R. Huggins, P. Thompson. 2011. Well-being and competitiveness: are the two linked at a place-based level?. Cambridge Journal of Regions, Economy and Society . [Crossref]

249. Viola Angelini, Danilo Cavapozzi, Luca Corazzini, Omar Paccagnella. 2011. Age, Health and Life Satisfaction Among Older Europeans. Social Indicators Research . [Crossref]

250. Juncal Cuñado, Fernando Pérez Gracia. 2011. Does Education Affect Happiness? Evidence for Spain. Social Indicators Research . [Crossref]

251. Laetitia Duval, François-Charles Wolff. 2011. Longitudinal evidence on financial expectations in Albania. Economics of Transition no-no. [Crossref]

252. Katie Wright, Richard Black. 2011. POVERTY, MIGRATION AND HUMAN WELL-BEING: TOWARDS A POST-CRISIS RESEARCH AND POLICY AGENDA. Journal of International Development 23:4, 548-554. [Crossref]

253. Vincenzo Carrieri. 2011. SOCIAL COMPARISON AND SUBJECTIVE WELL-BEING: DOES THE HEALTH OF OTHERS MATTER?. Bulletin of Economic Research no-no. [Crossref]

254. Cahit Guven. 2011. Are Happier People Better Citizens?. Kyklos 64:2, 178-192. [Crossref] 
255. Wenshu Gao, Russell Smyth. 2011. What keeps China's migrant workers going? Expectations and happiness among China's floating population. Journal of the Asia Pacific Economy 16:2, 163-182. [Crossref]

256. José Alberto Molina, María Navarro, Ian Walker. 2011. Intergenerational Well-Being Mobility in Europe. Kyklos 64:2, 253-270. [Crossref]

257. Christiane Gross, Andreas Jobst, Monika Jungbauer-Gans, Johannes Schwarze $†$. 2011. 9 Educational returns over the life course. Zeitschrift für Erziebungswissenschaft 14:S2, 139-153. [Crossref]

258. Harvey S. James Jr.. 2011. Is the Just Man a Happy Man? An Empirical Study of the Relationship between Ethics and Subjective Well-Being. Kyklos 64:2, 193-212. [Crossref]

259. Georgios Kavetsos, Pantelis Koutroumpis. 2011. Technological Affluence and Subjective Well-Being. Journal of Economic Psychology . [Crossref]

260. Hau Chyi, Shangyi Mao. 2011. The Determinants of Happiness of China's Elderly Population. Journal of Happiness Studies . [Crossref]

261. M. A. Choudhary, P. Levine, P. McAdam, P. Welz. 2011. The happiness puzzle: analytical aspects of the Easterlin paradox. Oxford Economic Papers . [Crossref]

262. John Cullis, John Hudson, Philip Jones. 2011. A Different Rationale for Redistribution: Pursuit of Happiness in the European Union. Journal of Happiness Studies 12:2, 323-341. [Crossref]

263. ANDREAS KNABE, STEFFEN RÄTZEL. 2011. Scarring or Scaring? The Psychological Impact of Past Unemployment and Future Unemployment Risk. Economica 78:310, 283-293. [Crossref]

264. Elizabeth W. Dunn, Daniel T. Gilbert, Timothy D. Wilson. 2011. If money doesn't make you happy, then you probably aren't spending it right. Journal of Consumer Psychology 21:2, 115-125. [Crossref]

265. Fabio D’Orlando, Francesco Ferrante, Gabriele Ruiu. 2011. Culturally based beliefs and labor market institutions. The Journal of Socio-Economics 40:2, 150-162. [Crossref]

266. Hung-Lin Tao. 2011. An empirical model on the fair and the second fair division of household labor. The Journal of Socio-Economics 40:2, 141-149. [Crossref]

267. Tetsuya Matsubayashi, Michiko Ueda. 2011. Government Partisanship and Human Well-Being. Social Indicators Research . [Crossref]

268. Di Wang, Alistair Sutcliffe, Xiao-Jun Zeng. 2011. A trust-based multi-ego social network model to investigate emotion diffusion. Social Network Analysis and Mining . [Crossref]

269. Emmanouil Mentzakis. 2011. Allowing for heterogeneity in monetary subjective well-being valuations. Health Economics 20:3, 331-347. [Crossref]

270. Jennifer L. Aaker, Melanie Rudd, Cassie Mogilner. 2011. If money does not make you happy, consider time. Journal of Consumer Psychology . [Crossref]

271. Wen-Chun Chang. 2011. Identity, Gender, and Subjective Well-Being. Review of Social Economy 69:1, 97-121. [Crossref]

272. E. D'Angelo, M. Lilla. 2011. Social networking and inequality: the role of clustered networks. Cambridge Journal of Regions, Economy and Society 4:1, 63-77. [Crossref]

273. Carlo V. Fiorio, Massimo Florio. 2011. «Would you say that the price you pay for electricity is fair?» Consumers' satisfaction and utility reforms in the EU15. Energy Economics 33:2, 178-187. [Crossref]

274. John Knight, Ramani Gunatilaka. 2011. Does Economic Growth Raise Happiness in China?. Oxford Development Studies 39:1, 1-24. [Crossref] 
275. Manel Baucells, Martin Weber, Frank Welfens. 2011. Reference-Point Formation and Updating. Management Science 57:3, 506-519. [Crossref]

276. Cheng-Lang Yang, Hung-Pin Lin, Chien-Yuan Chen. 2011. THE IMPACT OF ANTITERRORISM EXPENDITURE ON ECONOMIC GROWTH AND WELFARE. Bulletin of Economic Research no-no. [Crossref]

277. Bernard Praag. 2011. Well-being inequality and reference groups: an agenda for new research. The Journal of Economic Inequality 9:1, 111-127. [Crossref]

278. Leonardo Becchetti, Stefano Castriota, Nazaria Solferino. 2011. Development Projects and Life Satisfaction: An Impact Study on Fair Trade Handicraft Producers. Journal of Happiness Studies 12:1, 115-138. [Crossref]

279. Georgios Kavetsos. 2011. National Pride: War Minus the Shooting. Social Indicators Research . [Crossref]

280. Bidisha Mandal, Padmaja Ayyagari, William T. Gallo. 2011. Job loss and depression: The role of subjective expectations. Social Science \& Medicine 72:4, 576-583. [Crossref]

281. Luis Angeles. 2011. A closer look at the Easterlin Paradox. The Journal of Socio-Economics 40:1, 67-73. [Crossref]

282. Leonardo Becchetti, Giovanni Trovato, David Andres Londono Bedoya. 2011. Income, relational goods and happiness. Applied Economics 43:3, 273-290. [Crossref]

283. Hans-Jurgen Engelbrecht. 2011. Some empirics of the bivariate relationship between average subjective well-being and the sustainable wealth of nations. Applied Economics 1-18. [Crossref]

284. Christoph Fuchs, Martin Schreier. 2011. Customer Empowerment in New Product Development*. Journal of Product Innovation Management 28:1, 17-32. [Crossref]

285. H. Welsch. 2011. The magic triangle of macroeconomics: how do European countries score?. Oxford Economic Papers 63:1, 71-93. [Crossref]

286. Renske J. Hoefman, N. Job A. Exel, Sandra Looren de Jong, W. Ken Redekop, Werner B. F. Brouwer. 2011. A new test of the construct validity of the CarerQol instrument: measuring the impact of informal care giving. Quality of Life Research . [Crossref]

287. Marc Fleurbaey, Erik Schokkaert. Equity in Health and Health Care11This chapter was written when Marc Fleurbaey was research associate at CORE. We thank Chiara Canta, Tom McGuire, Tom van Ourti and Fred Schrogen for their useful comments 1003-1092. [Crossref]

288. Miao Wang, Man Chiu Sunny Wong. 2011. Leisure and happiness in the United States: evidence from survey data. Applied Economics Letters 1-4. [Crossref]

289. Arthur J. Robson, Larry Samuelson. The Evolutionary Foundations of Preferences 221-310. [Crossref]

290. Eiji Yamamura. 2011. The Influence of Government Size on Economic Growth and Life Satisfaction. Japanese Economy 38:4, 28-64. [Crossref]

291. Marc Hooghe, Bram Vanhoutte. 2011. Subjective Well-Being and Social Capital in Belgian Communities. The Impact of Community Characteristics on Subjective Well-Being Indicators in Belgium. Social Indicators Research 100:1, 17-36. [Crossref]

292. Diego García, Günter Strobl. 2011. Relative Wealth Concerns and Complementarities in Information Acquisition. Review of Financial Studies 24:1, 169-207. [Crossref] 
293. R. A. Easterlin, L. A. McVey, M. Switek, O. Sawangfa, J. S. Zweig. 2010. The happiness-income paradox revisited. Proceedings of the National Academy of Sciences 107:52, 22463-22468. [Crossref]

294. Nikolas Papavlassopulos, David Keppler. 2010. Life Expectancy as an Objective Factor of a Subjective Well-Being. Social Indicators Research . [Crossref]

295. Carsten Ochsen, Heinz Welsch. 2010. The social costs of unemployment: accounting for unemployment duration. Applied Economics 1-7. [Crossref]

296. John Haisken-DeNew, Mathias Sinning. 2010. SOCIAL DEPRIVATION OF IMMIGRANTS IN GERMANY. Review of Income and Wealth 56:4, 715-733. [Crossref]

297. Takashi Oshio, Kayo Nozaki, Miki Kobayashi. 2010. Relative Income and Happiness in Asia: Evidence from Nationwide Surveys in China, Japan, and Korea. Social Indicators Research . [Crossref]

298. Inmaculada Garcia, Jose-Alberto Molina, Maria Navarro. 2010. The effects of education on spouses' satisfaction in Europe. Applied Economics 42:28, 3607-3618. [Crossref]

299. Martin Binder, Alex Coad. 2010. An examination of the dynamics of well-being and life events using vector autoregressions. Journal of Economic Behavior \& Organization 76:2, 352-371. [Crossref]

300. Konstantinos Pouliakas. 2010. Pay Enough, Don't Pay Too Much or Don't Pay at All? The Impact of Bonus Intensity on Job Satisfaction. Kyklos 63:4, 597-626. [Crossref]

301. Liam Graham, Andrew J. Oswald. 2010. Hedonic capital, adaptation and resilience\#. Journal of Economic Behavior \& Organization 76:2, 372-384. [Crossref]

302. Dirk Wolfson. 2010. Situational Contracting as a Mode of Governance. Public Management Review 12:6, 857-872. [Crossref]

303. Eszter Siposné Nándori. 2010. Subjective Poverty and Its Relation to Objective Poverty Concepts in Hungary. Social Indicators Research . [Crossref]

304. Linnea A. Polgreen, Nicole B. Simpson. 2010. Happiness and International Migration. Journal of Happiness Studies . [Crossref]

305. Dorrit Ruth Posel, Daniela Maria Casale. 2010. Relative Standing and Subjective Well-Being in South Africa: The Role of Perceptions, Expectations and Income Mobility. Social Indicators Research . [Crossref]

306. B. Headey, R. Muffels, G. G. Wagner. 2010. Long-running German panel survey shows that personal and economic choices, not just genes, matter for happiness. Proceedings of the National Academy of Sciences 107:42, 17922-17926. [Crossref]

307. Tobias Menz, Heinz Welsch. 2010. Population aging and environmental preferences in OECD countries: The case of air pollution. Ecological Economics 69:12, 2582-2589. [Crossref]

308. Francisco Alvarez-Cuadrado, Ngo Van Long. 2010. Relative consumption and renewable resource extraction under alternative property-rights regimes. Resource and Energy Economics . [Crossref]

309. Dimitrios Varvarigos. 2010. Non-monotonic welfare dynamics in a growing economy. Journal of Macroeconomics . [Crossref]

310. Timothy A. Judge, Ronald F. Piccolo, Nathan P. Podsakoff, John C. Shaw, Bruce L. Rich. 2010. The relationship between pay and job satisfaction: A meta-analysis of the literature. Journal of Vocational Behavior 77:2, 157-167. [Crossref] 
311. Takashi Oshio, Shinpei Sano, Miki Kobayashi. 2010. Child Poverty as a Determinant of Life Outcomes: Evidence from Nationwide Surveys in Japan. Social Indicators Research 99:1, 81-99. [Crossref]

312. KONSTANTINOS POULIAKAS, IOANNIS THEODOSSIOU. 2010. Measuring the Utility Cost of Temporary Employment Contracts Before Adaptation: A Conjoint Analysis Approach. Economica 77:308, 688-709. [Crossref]

313. Luca Stanca. 2010. The Geography of Economics and Happiness: Spatial Patterns in the Effects of Economic Conditions on Well-Being. Social Indicators Research 99:1, 115-133. [Crossref]

314. Ricardo Pagán-Rodríguez. 2010. Onset of disability and life satisfaction: evidence from the German Socio-Economic Panel. The European Journal of Health Economics 11:5, 471-485. [Crossref]

315. Bruno S. Frey, Simon Luechinger, Alois Stutzer. 2010. The Life Satisfaction Approach to Environmental Valuation. Annual Review of Resource Economics 2:1, 139-160. [Crossref]

316. Luna Bellani, Conchita D’Ambrosio. 2010. Deprivation, Social Exclusion and Subjective Well-Being. Social Indicators Research . [Crossref]

317. Russell Smyth, Ingrid Nielsen, Qingguo Zhai, Tiemin Liu, Yin Liu, Chunyong Tang, Zhihong Wang, Zuxiang Wang, Juyong Zhang. 2010. A study of the impact of environmental surroundings on personal well-being in urban China using a multi-item well-being indicator. Population and Environment . [Crossref]

318. Takashi Oshio, Miki Kobayashi. 2010. Area-Level Income Inequality and Individual Happiness: Evidence from Japan. Journal of Happiness Studies . [Crossref]

319. B Mak Arvin, Byron Lew. 2010. Does Happiness Affect the Bilateral Aid Flows Between Donor and Recipient Countries?. European Journal of Development Research 22:4, 546-563. [Crossref]

320. Andreas Knabe, Steffen Rätzel, Ronnie Schöb, Joachim Weimann. 2010. Dissatisfied with Life but Having a Good Day: Time-use and Well-being of the Unemployed*. The Economic Journal 120:547, 867-889. [Crossref]

321. Bruno S. Frey, Alois Stutzer. 2010. Happiness and public choice. Public Choice 144:3-4, 557-573. [Crossref]

322. Anne K. Soutter, Alison Gilmore, Billy O’Steen. 2010. How do High School Youths' Educational Experiences Relate to Well-Being? Towards a Trans-Disciplinary Conceptualization. Journal of Happiness Studies . [Crossref]

323. Sigit Dwiananto Arifwidodo, Ranjith Perera. 2010. Quality of Life and Compact Development Policies in Bandung, Indonesia. Applied Research in Quality of Life . [Crossref]

324. Ada Ferrer-i-Carbonell, Klarita Gërxhani. 2010. Financial Satisfaction and (in)formal Sector in a Transition Country. Social Indicators Research . [Crossref]

325. Miguel Pereira Lopes, Patricia Jardim Palma, Miguel Pina e Cunha. 2010. Tolerance is Not Enough: The Moderating Role of Optimism on Perceptions of Regional Economic Performance. Social Indicators Research . [Crossref]

326. Andreas Knabe, Steffen Ratzel. 2010. Quantifying the psychological costs of unemployment: the role of permanent income. Applied Economics 1-13. [Crossref]

327. Jeroen C. J. M. Bergh. 2010. Safe climate policy is affordable-12 reasons. Climatic Change 101:3-4, 339-385. [Crossref] 
328. Laura Camfield, Monica Guillen-Royo, Jackeline Velazco. 2010. Does Needs Satisfaction Matter for Psychological and Subjective Wellbeing in Developing Countries: A Mixed-Methods Illustration from Bangladesh and Thailand. Journal of Happiness Studies 11:4, 497-516. [Crossref]

329. Simon Davies, Tim Hinks. 2010. Crime and Happiness Amongst Heads of Households in Malawi. Journal of Happiness Studies 11:4, 457-476. [Crossref]

330. Mikael Priks. 2010. Does Frustration Lead to Violence? Evidence from the Swedish Hooligan Scene. Kyklos 63:3, 450-460. [Crossref]

331. Christopher J. Boyce, Alex M. Wood, Gordon D.A. Brown. 2010. The dark side of conscientiousness: Conscientious people experience greater drops in life satisfaction following unemployment. Journal of Research in Personality 44:4, 535-539. [Crossref]

332. Peigang Wang, Tyler J. VanderWeele. 2010. Empirical Research on Factors Related to the Subjective Well-Being of Chinese Urban Residents. Social Indicators Research . [Crossref]

333. Laura Camfield, Natalia Streuli, Martin Woodhead. 2010. Children's Well-being in Developing Countries: A Conceptual and Methodological Review. European Journal of Development Research 22:3, 398-416. [Crossref]

334. Ana Bobinac, N. Job A. van Exel, Frans F.H. Rutten, Werner B.F. Brouwer. 2010. Caring for and caring about: Disentangling the caregiver effect and the family effect. Journal of Health Economics 29:4, 549-556. [Crossref]

335. Susana Ferreira, Mirko Moro. 2010. On the Use of Subjective Well-Being Data for Environmental Valuation. Environmental and Resource Economics 46:3, 249-273. [Crossref]

336. D. W. Hands. 2010. Economics, psychology and the history of consumer choice theory. Cambridge Journal of Economics 34:4, 633-648. [Crossref]

337. Rafael Lalive, Alois Stutzer. 2010. Approval of equal rights and gender differences in well-being. Journal of Population Economics 23:3, 933-962. [Crossref]

338. Fredrik Carlsson. 2010. Design of Stated Preference Surveys: Is There More to Learn from Behavioral Economics?. Environmental and Resource Economics 46:2, 167-177. [Crossref]

339. Luc Van Ootegem, Sophie Spillemaeckers. 2010. With a focus on well-being and capabilities. The Journal of Socio-Economics 39:3, 384-390. [Crossref]

340. Wen-Chieh Wu, Hui-Pei Cheng. 2010. Symmetric mortality and asymmetric suicide cycles. Social Science \& Medicine 70:12, 1974-1981. [Crossref]

341. André van Hoorn, Ramzi Mabsout, Esther-Mirjam Sent. 2010. Happiness and capability: Introduction to the symposium. The Journal of Socio-Economics 39:3, 339-343. [Crossref]

342. Eduardo Pérez-Asenjo. 2010. If happiness is relative, against whom do we compare ourselves? Implications for labour supply. Journal of Population Economics . [Crossref]

343. Ambrose Leung, Cheryl Kier, Tak Fung, Linda Fung, Robert Sproule. 2010. Searching for Happiness: The Importance of Social Capital. Journal of Happiness Studies . [Crossref]

344. Christian Niedermeyer, Peter Jaskiewicz, Sabine Klein. 2010. 'Can't get no satisfaction?' Evaluating the sale of the family business from the family's perspective and deriving implications for new venture activities. Entrepreneurship \& Regional Development 22:3, 293-320. [Crossref]

345. Y. Hossein Farzin. 2010. Sustainability, Optimality, and Development Policy. Review of Development Economics 14:2, 262-281. [Crossref] 
346. Takashi Oshio, Miki Kobayashi. 2010. Income inequality, perceived happiness, and self-rated health: Evidence from nationwide surveys in Japan\#\#\#. Social Science \& Medicine 70:9, 1358-1366. [Crossref]

347. André Duarte, Camila Garcia, Grigoris Giannarakis, Susana Limão, Amalia Polydoropoulou, Nikolaos Litinas. 2010. New approaches in transportation planning: happiness and transport economics. NETNOMICS: Economic Research and Electronic Networking 11:1, 5-32. [Crossref]

348. Frederic Tournemaine, Christopher Tsoukis. 2010. Gain versus pain from status and ambition: Effects on growth and inequality. The Journal of Socio-Economics 39:2, 286-294. [Crossref]

349. James Konow. 2010. Mixed feelings: Theories of and evidence on giving. Journal of Public Economics 94:3-4, 279-297. [Crossref]

350. Grant Duncan. 2010. Should Happiness-Maximization be the Goal of Government?. Journal of Happiness Studies 11:2, 163-178. [Crossref]

351. L. Unnevehr, J. Eales, H. Jensen, J. Lusk, J. McCluskey, J. Kinsey. 2010. Food and Consumer Economics. American Journal of Agricultural Economics 92:2, 506-521. [Crossref]

352. John Knight, Li Shi, Deng Quheng. 2010. Education and the Poverty Trap in Rural China: Closing the Trap. Oxford Development Studies 38:1, 1-24. [Crossref]

353. Joshua J. Dyck, Nicholas R. Seabrook. 2010. Mobilized by Direct Democracy: Short-Term Versus Long-Term Effects and the Geography of Turnout in Ballot Measure Elections. Social Science Quarterly 91:1, 188-208. [Crossref]

354. Wen Xin, Russell Smyth. 2010. Economic Openness and Subjective Well-being in China. China \& World Economy 18:2, 22-40. [Crossref]

355. John Knight, Ramani Gunatilaka. 2010. The Rural-Urban Divide in China: Income but Not Happiness?. Journal of Development Studies 46:3, 506-534. [Crossref]

356. Tomi Ovaska, Ryo Takashima. 2010. Does a Rising Tide Lift All the Boats? Explaining the National Inequality of Happiness. Journal of Economic Issues 44:1, 205-224. [Crossref]

357. Kerry Joyce, Roman Pabayo, Julia A Critchley, Clare Bambra. Flexible working conditions and their effects on employee health and wellbeing . [Crossref]

358. Eva M. Berger. 2010. The Chernobyl Disaster, Concern about the Environment, and Life Satisfaction. Kyklos 63:1, 1-8. [Crossref]

359. Anand M. Goel, Anjan V. Thakor. 2010. Do Envious CEOs Cause Merger Waves?. Review of Financial Studies 23:2, 487-517. [Crossref]

360. Ross S. Guest, Ian M. McDonald. 2010. OTHER-REGARDING UZAWA PREFERENCES AND LIVING STANDARD CATCH-UP. Pacific Economic Review 15:1, 87-115. [Crossref]

361. Maya Abou-Zeid, Moshe Ben-Akiva. A Model of Travel Happiness and Mode Switching 289-305. [Crossref]

362. Douglas Bernheim. 2010. Behavioral welfare economics. Panoeconomicus 57:2, 123-151. [Crossref]

363. Bernd Hayo, Hiroyuki Ono. 2010. Comparing public attitudes toward providing for the livelihood of the elderly in two aging societies: Germany and Japan. The Journal of Socio-Economics 39:1, 72-80. [Crossref]

364. C.G.E. Kelley, S.M.C. Kelley, M.D.R. Evans, J. Kelley. 2010. Attitudes toward home-based employment for mothers of young children: Australian evidence. International Journal of Social Welfare 19:1, 33-44. [Crossref] 
365. Russell Smyth, Ingrid Nielsen, Qingguo Zhai. 2010. Personal Well-being in Urban China. Social Indicators Research 95:2, 231-251. [Crossref]

366. Hans-Jürgen Engelbrecht. 2009. Natural capital, subjective well-being, and the new welfare economics of sustainability: Some evidence from cross-country regressions. Ecological Economics 69:2, 380-388. [Crossref]

367. Martin Hiermeyer. 2009. Height and BMI values of German conscripts in 2000, 2001 and 1906. Economics \& Human Biology 7:3, 366-375. [Crossref]

368. Kurt Rothschild. 2009. A nostalgic retrospect on a debate on various aspects of welfare economics. The European Journal of the History of Economic Thought 16:4, 559-574. [Crossref]

369. Paul Frijters, Harry Greenwell, John P. Haisken-DeNew, Michael A. Shields. 2009. How well do individuals predict their future life satisfaction? Evidence from panel data following a nationwide exogenous shock. Canadian Journal of Economics/Revue canadienne d'économique 42:4, 1326-1346. [Crossref]

370. Luiz de Mello, Erwin R. Tiongson. 2009. What Is the Value of (My and My Family's) Good Health?. Kyklos 62:4, 594-610. [Crossref]

371. Adrian Bruhin, Rainer Winkelmann. 2009. Happiness functions with preference interdependence and heterogeneity: the case of altruism within the family. Journal of Population Economics 22:4, 1063-1080. [Crossref]

372. Ming-Chang Tsai. 2009. Market Openness, Transition Economies and Subjective Wellbeing. Journal of Happiness Studies 10:5, 523-539. [Crossref]

373. Astrid Hopfensitz, Ernesto Reuben. 2009. The Importance of Emotions for the Effectiveness of Social Punishment. The Economic Journal 119:540, 1534-1559. [Crossref]

374. Robert W. Wassmer, Edward L. Lascher, Stephan Kroll. 2009. Sub-national Fiscal Activity as a Determinant of Individual Happiness: Ideology Matters. Journal of Happiness Studies 10:5, 563-582. [Crossref]

375. Heinz Welsch. 2009. Implications of happiness research for environmental economics. Ecological Economics 68:11, 2735-2742. [Crossref]

376. Udo Ebert, Heinz Welsch. 2009. HOW DO EUROPEANS EVALUATE INCOME DISTRIBUTIONS? AN ASSESSMENT BASED ON HAPPINESS SURVEYS. Review of Income and Wealth 55:3, 803-819. [Crossref]

377. Maurizio Pugno. 2009. The Easterlin paradox and the decline of social capital: An integrated explanation. The Journal of Socio-Economics 38:4, 590-600. [Crossref]

378. Takashi Oshio, Miki Kobayashi. 2009. Income inequality, area-level poverty, perceived aversion to inequality, and self-rated health in Japan. Social Science \& Medicine 69:3, 317-326. [Crossref]

379. Wen-Chun Chang. 2009. Social capital and subjective happiness in Taiwan. International Journal of Social Economics 36:8, 844-868. [Crossref]

380. Philipp C. Wichardt. 2009. A status-based motivation for behavioural altruism. International Journal of Social Economics 36:8, 869-887. [Crossref]

381. B. Curtis Eaton, Mukesh Eswaran. 2009. Well-being and Affluence in the Presence of a Veblen Good. The Economic Journal 119:539, 1088-1104. [Crossref] 
382. Anders Hayden, John Shandra. 2009. Hours of work and the ecological footprint of nations: an exploratory analysis. Local Environment 14:6, 575-600. [Crossref]

383. Marcel Fafchamps, Bart Minten. 2009. Insecurity and Welfare: Evidence from County Data. The Journal of Development Studies 45:6, 831-863. [Crossref]

384. Nguyen Minh Duc. 2009. Contribution of Fish Production to Farmers' Subjective Well-being in Vietnam - A Logistic Model. Journal of the World Aquaculture Society 40:3, 417-424. [Crossref]

385. Hikaru Hasegawa. 2009. Bayesian Dynamic Panel-Ordered Probit Model and Its Application to Subjective Well-Being. Communications in Statistics - Simulation and Computation 38:6, 1321-1347. [Crossref]

386. Mary Steffel, Daniel M. Oppenheimer. 2009. Happy by What Standard? The Role of Interpersonal and Intrapersonal Comparisons in Ratings of Happiness. Social Indicators Research 92:1, 69-79. [Crossref]

387. Sergei Guriev, Ekaterina Zhuravskaya,. 2009. (Un)Happiness in Transition. Journal of Economic Perspectives 23:2, 143-168. [Abstract] [View PDF article] [PDF with links]

388. Michael A. Shields, Stephen Wheatley Price, Mark Wooden. 2009. Life satisfaction and the economic and social characteristics of neighbourhoods. Journal of Population Economics 22:2, 421-443. [Crossref]

389. Conchita D'Ambrosio, Joachim R Frick, Markus Jäntti. 2009. Satisfaction with Life and Economic Well-Being: Evidence from Germany. Schmollers Jabrbuch 129:2, 283-295. [Crossref]

390. Nick Carroll, Paul Frijters, Michael A. Shields. 2009. Quantifying the costs of drought: new evidence from life satisfaction data. Journal of Population Economics 22:2, 445-461. [Crossref]

391. Christoph Wunder. 2009. Adaptation to Income Over Time: A Weak Point of Subjective Well-Being. Schmollers Jabrbuch 129:2, 269-281. [Crossref]

392. Stefan Borsky, Paul A. Raschky. 2009. The Hedonics of Hedonism - Estimating the Value of RiskTaking Activities. Kyklos 62:2, 210-225. [Crossref]

393. Heinz Welsch, Jan Kühling. 2009. USING HAPPINESS DATA FOR ENVIRONMENTAL VALUATION: ISSUES AND APPLICATIONS. Journal of Economic Surveys 23:2, 385-406. [Crossref]

394. Joern Block, Philipp Koellinger. 2009. I Can't Get No Satisfaction-Necessity Entrepreneurship and Procedural Utility. Kyklos 62:2, 191-209. [Crossref]

395. Jens Bonke, Mette Deding, Mette Lausten. 2009. Time and Money. Journal of Happiness Studies 10:2, 113-131. [Crossref]

396. Bruno S. Frey, Simon Luechinger, Alois Stutzer. 2009. The life satisfaction approach to valuing public goods: The case of terrorism. Public Choice 138:3-4, 317-345. [Crossref]

397. Philip H. Brown, Brian Tierney. 2009. Religion and subjective well-being among the elderly in China. The Journal of Socio-Economics 38:2, 310-319. [Crossref]

398. Sonja C. Kassenboehmer, John P. Haisken-DeNew. 2009. You're Fired! The Causal Negative Effect of Entry Unemployment on Life Satisfaction. The Economic Journal 119:536, 448-462. [Crossref]

399. David Clark. 2009. Adaptation, Poverty and Well-Being: Some Issues and Observations with Special Reference to the Capability Approach and Development Studies. Journal of Human Development and Capabilities 10:1, 21-42. [Crossref] 
400. S. M. C. Kelley, C. G. E. Kelley, M. D. R. Evans, J. Kelley. 2009. Support for Mothers' Employment at Home: Conflict between Work and Family. International Journal of Public Opinion Research 21:1, 98-110. [Crossref]

401. Simon Luechinger. 2009. Valuing Air Quality Using the Life Satisfaction Approach. The Economic Journal 119:536, 482-515. [Crossref]

402. BLANE D. LEWIS, DAAN PATTINASARANY. 2009. Determining Citizen Satisfaction with Local Public Education in Indonesia: The Significance of Actual Service Quality and Governance Conditions. Growth and Change 40:1, 85-115. [Crossref]

403. Sascha L. Schmidt, Benno Torgler, Bruno S. Frey. 2009. Die Auswirkungen von Neid auf individuelle Leistungen: Ergebnisse einer Panelanalyse. Zeitschrift für Betriebswirtschaft 79:3, 303-334. [Crossref]

404. Thomas Dohmen, Armin Falk, David Huffman, Uwe Sunde. 2009. Homo Reciprocans: Survey Evidence on Behavioural Outcomes. The Economic Journal 119:536, 592-612. [Crossref]

405. Shahid Yusuf. 2009. From creativity to innovation. Technology in Society 31:1, 1-8. [Crossref]

406. Tiziana Cuccia, Roberto Cellini. 2009. WORKERS' ENTERPRISES AND THE TASTE FOR PRODUCTION: THE ARTS, SPORT AND OTHER CASES. Scottish Journal of Political Economy 56:1, 123-137. [Crossref]

407. Valérie Clément, Nathalie Moureau, Marion Vidal. 2009. À la recherche des biens sous tutelle. L'Actualité économique 85:4, 383. [Crossref]

408. Emmanouil Mentzakis, Mirko Moro. 2009. The poor, the rich and the happy: Exploring the link between income and subjective well-being. The Journal of Socio-Economics 38:1, 147-158. [Crossref]

409. Leonardo Becchetti, Fiammetta Rossetti. 2009. When money does not buy happiness: The case of "frustrated achievers". The Journal of Socio-Economics 38:1, 159-167. [Crossref]

410. Fabio D’Orlando, Francesco Ferrante. 2009. The demand for job protection. The Journal of SocioEconomics 38:1, 104-114. [Crossref]

411. Valérie Clément. 2009. Economie du bien-être, choix social et l'influence de la Théorie de la justice. Raisons politiques 33:1, 57. [Crossref]

412. Philippe Tessier. 2009. Harsanyi, Sen ou Bentham. Revue économique 60:6, 1309. [Crossref]

413. R SMYTH, V MISHRA, X QIAN. 2008. The Environment and Well-Being in Urban China. Ecological Economics 68:1-2, 547-555. [Crossref]

414. M HIERMEYER. 2008. The trade-off between a high and an equal biological standard of livingEvidence from Germany. Economics \& Human Biology 6:3, 431-445. [Crossref]

415. John Komlos, Peter Salamon. 2008. The poverty of growth with interdependent utility functions. The Journal of Socio-Economics 37:6, 2242-2247. [Crossref]

416. N DUC. 2008. Farmers' satisfaction with aquaculture - A logistic model in Vietnam. Ecological Economics 68:1-2, 525-531. [Crossref]

417. Michael H. Huesemann, Joyce A. Huesemann. 2008. Will progress in science and technology avert or accelerate global collapse? A critical analysis and policy recommendations. Environment, Development and Sustainability 10:6, 787-825. [Crossref]

418. Sule Alan, Kadir Atalay, Thomas F. Crossley. 2008. The Adequacy of Retirement Savings: Subjective Survey Reports by Retired Canadians. Canadian Public Policy 34:4, S95-S118. [Crossref] 
419. Jens Bonke. 2008. Income distribution and financial satisfaction between spouses in Europe. The Journal of Socio-Economics 37:6, 2291-2303. [Crossref]

420. Ann L. Owen, Julio Videras, Christina Willemsen. 2008. Democracy, Participation, and Life Satisfaction *. Social Science Quarterly 89:4, 987-1005. [Crossref]

421. Ed Hopkins. 2008. Inequality, happiness and relative concerns: What actually is their relationship?. The Journal of Economic Inequality 6:4, 351-372. [Crossref]

422. Russell N. James. 2008. Impact of Subsidized Rental Housing Characteristics on Metropolitan Residential Satisfaction. Journal of Urban Planning and Development 134:4, 166-172. [Crossref]

423. Andrew Clark, Nathalie Colombier, David Masclet. 2008. Never the same after the first time: the satisfaction of the second-generation self-employed. International Journal of Manpower 29:7, 591-609. [Crossref]

424. Yannis Georgellis, Andros Gregoriou, Jerome Healy, Nikolaos Tsitsianis. 2008. Unemployment and life satisfaction: a non-linear adaptation process. International Journal of Manpower 29:7, 668-680. [Crossref]

425. Juan Pablo Couyoumdjian. 2008. An Expert at Work: Revisiting Jeremy Bentham's Proposals on Codification. Kyklos 61:4, 503-519. [Crossref]

426. Sule Alan, Kadir Atalay, Thomas F. Crossley. 2008. The Adequacy of Retirement Savings: Subjective Survey Reports by Retired Canadians. Canadian Public Policy 34:s1, S95-S118. [Crossref]

427. Jens Alber, Ulrich Kohler. 2008. Informal Food Production in the Enlarged European Union. Social Indicators Research 89:1, 113-127. [Crossref]

428. Ermanno C. Tortia. 2008. Worker well-being and perceived fairness: Survey-based findings from Italy. The Journal of Socio-Economics 37:5, 2080-2094. [Crossref]

429. Tim Hinks, Simon Davies. 2008. Life satisfaction in Malawi and the importance of relative consumption, polygamy and religion. Journal of International Development 20:7, 888-904. [Crossref]

430. Andreas Hadjar, Sigrid Haunberger, Frank Schubert. 2008. Bildung und subjektives Wohlbefinden im Zeitverlauf, 1984-2002:. Berliner Journal für Soziologie 18:3, 370-400. [Crossref]

431. Ulrich Schimmack, Jürgen Schupp, Gert G. Wagner. 2008. The Influence of Environment and Personality on the Affective and Cognitive Component of Subjective Well-being. Social Indicators Research 89:1, 41-60. [Crossref]

432. Sibel Selim. 2008. Life Satisfaction and Happiness in Turkey. Social Indicators Researcb 88:3, 531-562. [Crossref]

433. J COSTAFONT. 2008. Housing assets and the socio-economic determinants of health and disability in old age. Health \& Place 14:3, 478-491. [Crossref]

434. George J. Bratsiotis, Baochun Peng. 2008. Social interaction and effort in a success-at-work augmented utility model. The Journal of Socio-Economics 37:4, 1309-1318. [Crossref]

435. Aaron Ahuvia. 2008. If money doesn't make us happy, why do we act as if it does?. Journal of Economic Psychology 29:4, 491-507. [Crossref]

436. Leonardo Becchetti, Alessandra Pelloni, Fiammetta Rossetti. 2008. Relational Goods, Sociability, and Happiness. Kyklos 61:3, 343-363. [Crossref]

437. CLAUDIA SENIK. 2008. Ambition and Jealousy: Income Interactions in the âOldâ Europe versus the âNewâ Europe and the United States. Economica 75:299, 495-513. [Crossref] 
438. Ed Diener, Pelin Kesebir, Richard Lucas. 2008. Benefits of Accounts of Well-Being- For Societies and for Psychological Science. Applied Psychology 57:s1, 37-53. [Crossref]

439. R SCUTELLA, M WOODEN. 2008. The effects of household joblessness on mental health\#. Social Science \& Medicine 67:1, 88-100. [Crossref]

440. Heinz Welsch. 2008. The welfare costs of corruption. Applied Economics 40:14, 1839-1849. [Crossref]

441. David Dorn, Justina A. V. Fischer, Gebhard Kirchgässner, Alfonso Sousa-Poza. 2008. Direct democracy and life satisfaction revisited: new evidence for Switzerland. Journal of Happiness Studies 9:2, 227-255. [Crossref]

442. Alois Stutzer, Bruno S. Frey. 2008. Stress that Doesn't Pay: The Commuting Paradox*. Scandinavian Journal of Economics 110:2, 339-366. [Crossref]

443. Petra Böhnke. 2008. Does Society Matter? Life Satisfaction in the Enlarged Europe. Social Indicators Research 87:2, 189-210. [Crossref]

444. d. mahadea, t. rawat. 2008. ECONOMIC GROWTH, INCOME AND HAPPINESS: AN EXPLORATORY STUDY. South African Journal of Economics 76:2, 276-290. [Crossref]

445. Heinz Welsch, Udo Bonn. 2008. Economic convergence and life satisfaction in the European Union. The Journal of Socio-Economics 37:3, 1153-1167. [Crossref]

446. Stavros A. Drakopoulos. 2008. The paradox of happiness: towards an alternative explanation. Journal of Happiness Studies 9:2, 303-315. [Crossref]

447. YEW-KWANG NG. 2008. Happiness Studies: Ways to Improve Comparability and Some Public Policy Implications. Economic Record 84:265, 253-266. [Crossref]

448. Elia Kacapyr. 2008. Cross-country determinants of satisfaction with life. International Journal of Social Economics 35:6, 400-416. [Crossref]

449. MATTHIAS BENZ, BRUNO S. FREY. 2008. Being Independent is a Great Thing: Subjective Evaluations of Self-Employment and Hierarchy. Economica 75:298, 362-383. [Crossref]

450. I SCHUMACHER, B ZOU. 2008. Pollution perception: A challenge for intergenerational equity. Journal of Environmental Economics and Management 55:3, 296-309. [Crossref]

451. Benno Torgler, Nemanja Antić, Uwe Dulleck. 2008. Mirror, Mirror on the Wall, Who Is the Happiest of Them All?. Kyklos 61:2, 309-319. [Crossref]

452. Heinz Welsch. 2008. The Social Costs of Civil Conflict: Evidence from Surveys of Happiness. Kyklos 61:2, 320-340. [Crossref]

453. Bruce Headey, Ruud Muffels, Mark Wooden. 2008. Money Does not Buy Happiness: Or Does It? A Reassessment Based on the Combined Effects of Wealth, Income and Consumption. Social Indicators Research 87:1, 65-82. [Crossref]

454. Christopher K. Hsee, Reid Hastie, Jingqiu Chen. 2008. Hedonomics: Bridging Decision Research With Happiness Research. Perspectives on Psychological Science 3:3, 224-243. [Crossref]

455. Mirko Moro, Finbarr Brereton, Susana Ferreira, J. Peter Clinch. 2008. Ranking quality of life using subjective well-being data. Ecological Economics 65:3, 448-460. [Crossref]

456. Felix Schläpfer, Marcel Schmitt, Anna Roschewitz. 2008. Competitive politics, simplified heuristics, and preferences for public goods. Ecological Economics 65:3, 574-589. [Crossref]

457. R DITELLA, R MACCULLOCH. 2008. Gross national happiness as an answer to the Easterlin Paradox?\#. Journal of Development Economics 86:1, 22-42. [Crossref] 
458. Stephan Klasen. 2008. The Efficiency of Equity. Review of Political Economy 20:2, 257-274. [Crossref]

459. Hung-Lin Tao. 2008. What makes devout Christians happier? Evidence from Taiwan. Applied Economics 40:7, 905-919. [Crossref]

460. Finbarr Brereton, J. Peter Clinch, Susana Ferreira. 2008. Happiness, geography and the environment. Ecological Economics 65:2, 386-396. [Crossref]

461. Benjamin E. Hermalin, Alice M. Isen. 2008. A model of the effect of affect on economic decision making. Quantitative Marketing and Economics 6:1, 17-40. [Crossref]

462. Gundi Knies, Simon Burgess, Carol Propper. 2008. Keeping up with the Schmidt's - An Empirical Test of Relative Deprivation Theory in the Neighbourhood Context. Schmollers Jabrbuch 128:1, 75-108. [Crossref]

463. Andrew E. Clark,, Paul Frijters,, Michael A. Shields. 2008. Relative Income, Happiness, and Utility: An Explanation for the Easterlin Paradox and Other Puzzles. Journal of Economic Literature 46:1, 95-144. [Abstract] [View PDF article] [PDF with links]

464. Pernilla Andersson. 2008. Happiness and health: Well-being among the self-employed. The Journal of Socio-Economics 37:1, 213-236. [Crossref]

465. Paul Dolan, Daniel Kahneman. 2008. Interpretations Of Utility And Their Implications For The Valuation Of Health*. The Economic Journal 118:525, 215-234. [Crossref]

466. Thomas Wai-kee Yuen, Winnie Wan-Ling Chu. 2008. Expected Happiness in Chinese Lunar New Year, Christmas and Western New Year: A Survey Study in Hong Kong. The Journal of Comparative Asian Development 7:2, 309-328. [Crossref]

467. Wang-Sheng Lee, Umut Oguzoglu. 2007. Income Support and Stigma Effects for Young Australians. Australian Economic Review 40:4, 369-384. [Crossref]

468. W BROUWER, A CULYER, N VANEXEL, F RUTTEN. 2007. Welfarism vs. extra-welfarism. Journal of Health Economics . [Crossref]

469. Yew-Kwang Ng. 2007. Environmentally Responsible Happy Nation Index: Towards an Internationally Acceptable National Success Indicator. Social Indicators Research 85:3, 425-446. [Crossref]

470. Gerrit Antonides. 2007. Income Evaluation and Happiness in the Case of an Income Decline. Kyklos 60:4, 467-484. [Crossref]

471. Erik Schokkaert. 2007. Capabilities and Satisfaction with Life. Journal of Human Development 8:3, 415-430. [Crossref]

472. Bernard van den Berg, Ada Ferrer-i-Carbonell. 2007. Monetary valuation of informal care: the wellbeing valuation method. Health Economics 16:11, 1227-1244. [Crossref]

473. Francisco Alvarez-Cuadrado. 2007. Envy, leisure, and restrictions on working hours. Canadian Journal of Economics/Revue canadienne d'économique 40:4, 1286-1310. [Crossref]

474. Peter Sanfey, Utku Teksoz. 2007. Does transition make you happy?. The Economics of Transition 15:4, 707-731. [Crossref]

475. Dionysia Lambiri, Bianca Biagi, Vicente Royuela. 2007. Quality of Life in the Economic and Urban Economic Literature. Social Indicators Research 84:1, 1-25. [Crossref]

476. STEPHAN MEIER, ALOIS STUTZER. 2007. Is Volunteering Rewarding in Itself?. Economica, ahead of print070924100058002-???. [Crossref] 
477. Craig R. Carter, Lutz Kaufmann, Alex Michel. 2007. Behavioral supply management: a taxonomy of judgment and decision-making biases. International Journal of Physical Distribution \& Logistics Management 37:8, 631-669. [Crossref]

478. M FAFCHAMPS, F SHILPI. 2007. Subjective welfare, isolation, and relative consumption\#. Journal of Development Economics . [Crossref]

479. NICK CARROLL. 2007. Unemployment and Psychological Well-being. Economic Record 83:262, 287-302. [Crossref]

480. Laura Camfield, Danny Ruta. 2007. 'Translation is not enough': using the Global Person Generated Index (GPGI) to assess individual quality of life in Bangladesh, Thailand, and Ethiopia. Quality of Life Research 16:6, 1039-1051. [Crossref]

481. Daniel Miles, Maximo Rossi. 2007. Learning about one's relative position and subjective well-being. Applied Economics 39:13, 1711-1718. [Crossref]

482. Sheila C. Dow. 2007. VARIETY OF METHODOLOGICAL APPROACH IN ECONOMICS. Journal of Economic Surveys 21:3, 447-465. [Crossref]

483. MARK WOODEN, NICOLE WATSON. 2007. The HILDA Survey and its Contribution to Economic and Social Research (So Far). Economic Record 83:261, 208-231. [Crossref]

484. Michael Demoussis, Nicholas Giannakopoulos. 2007. Exploring Job Satisfaction in Private and Public Employment: Empirical Evidence from Greece. Labour 21:2, 333-359. [Crossref]

485. David A. Penn. 2007. Estimating Missing Values from the General Social Survey: An Application of Multiple Imputation. Social Science Quarterly 88:2, 573-584. [Crossref]

486. A ZIDANSEK. 2007. Sustainable development and happiness in nations. Energy 32:6, 891-897. [Crossref]

487. Danny Ruta, Laura Camfield, Cam Donaldson. 2007. Sen and the art of quality of life maintenance: Towards a general theory of quality of life and its causation. The Journal of Socio-Economics 36:3, 397-423. [Crossref]

488. David Dorn, Justina A.V. Fischer, Gebhard Kirchgässner, Alfonso Sousa-Poza. 2007. Is It Culture or Democracy? The Impact of Democracy and Culture on Happiness. Social Indicators Research 82:3, 505-526. [Crossref]

489. Christopher T. Whelan, Bertrand Maitre. 2007. Income, deprivation and economic stress in the enlarged European Union. Social Indicators Research 83:2, 309-329. [Crossref]

490. LINA ERIKSSON, ROBERT E. GOODIN. 2007. The Measuring Rod of Time: The Example of Swedish Day-fines. Journal of Applied Philosophy 24:2, 125-136. [Crossref]

491. Heinz Welsch. 2007. Environmental welfare analysis: A life satisfaction approach. Ecological Economics 62:3-4, 544-551. [Crossref]

492. M ABDELLAOUI, C BARRIOS, P WAKKER. 2007. Reconciling introspective utility with revealed preference: Experimental arguments based on prospect theory. Journal of Econometrics 138:1, 356-378. [Crossref]

493. Nicolai Kristensen, Niels Westergaard-Nielsen. 2007. Reliability of job satisfaction measures. Journal of Happiness Studies 8:2, 273-292. [Crossref] 
494. Des Gasper. 2007. Uncounted or illusory blessings? Competing responses to the Easterlin, Easterbrook and Schwartz paradoxes of well-being. Journal of International Development 19:4, 473-492. [Crossref]

495. Hans-Jürgen Andreß, Miriam Bröckel. 2007. Income and Life Satisfaction After Marital Disruption in Germany. Journal of Marriage and Family 69:2, 500-512. [Crossref]

496. Timothy Hinks, Carola Gruen. 2007. What is the Structure of South African Happiness Equations? Evidence from Quality of Life Surveys. Social Indicators Research 82:2, 311-336. [Crossref]

497. Johannes Schwarze, Marco Härpfer. 2007. Are people inequality averse, and do they prefer redistribution by the state?. The Journal of Socio-Economics 36:2, 233-249. [Crossref]

498. Knut Veisten. 2007. Contingent valuation controversies: Philosophic debates about economic theory. The Journal of Socio-Economics 36:2, 204-232. [Crossref]

499. Eileen Trzcinski. 2007. Integration of immigrant mothers in Germany: policy issues and empirical outcomes. Population Research and Policy Review 25:5-6, 489-512. [Crossref]

500. Sara Connolly, Shaun P. Hargreaves Heap. 2007. Cross Country Differences in Trust in Television and the Governance of Public Broadcasters. Kyklos 60:1, 3-14. [Crossref]

501. Bruno S. Frey, Simon Luechinger, Alois Stutzer. 2007. CALCULATING TRAGEDY: ASSESSING THE COSTS OF TERRORISM. Journal of Economic Surveys 21:1, 1-24. [Crossref]

502. Lina Eriksson, James Mahmud Rice, Robert E. Goodin. 2007. Temporal Aspects of Life Satisfaction. Social Indicators Research 80:3, 511-533. [Crossref]

503. A FERRERICARBONELL, J GOWDY. 2007. Environmental degradation and happiness. Ecological Economics 60:3, 509-516. [Crossref]

504. Kevin Daniels, Olga Tregaskis, Jonathan S. Seaton. 2007. Job control and occupational health: the moderating role of national R\&D activity. Journal of Organizational Bebavior 28:1, 1-19. [Crossref]

505. Bart Nooteboom. 2007. Social capital, institutions and trust. Review of Social Economy 65:1, 29-53. [Crossref]

506. Luigino Bruni, Robert Sugden. 2007. The road not taken: how psychology was removed from economics, and how it might be brought back. The Economic Journal 117:516, 146-173. [Crossref]

507. James P. Johnson, J. Mark Muñoz, Ilan Alon. 2006. Filipino ethnic entrepreneurship: An integrated review and propositions. International Entrepreneurship and Management Journal 3:1, 69-85. [Crossref]

508. E. Colombatto. 2006. On economic growth and development. The Review of Austrian Economics 19:4, 243-260. [Crossref]

509. Brienna Perelli-Harris. 2006. The Influence of Informal Work and Subjective Well-Being on Childbearing in Post-Soviet Russia. Population and Development Review 32:4, 729-753. [Crossref]

510. Judith R. Cornelisse-Vermaat, Gerrit Antonides, Johan A. C. Ophem, Henriette Maassen Brink. 2006. Body Mass Index, Perceived Health, and Happiness: Their Determinants and Structural Relationships. Social Indicators Research 79:1, 143-158. [Crossref]

511. Geeta Kingdon, John Knight. 2006. Subjective well-being poverty vs . Income poverty and capabilities poverty?. The Journal of Development Studies 42:7, 1199-1224. [Crossref] 
512. Paul Frijters, Ingo Geishecker, John P. Haisken-DeNew, Michael A. Shields. 2006. Can the Large Swings in Russian Life Satisfaction be Explained by Ups and Downs in Real Incomes?. Scandinavian Journal of Economics 108:3, 433-458. [Crossref]

513. Lynn Mainwaring, Richard Jones, David Blackaby. 2006. Devolution, sustainability and GDP convergence: Is the Welsh agenda achievable?. Regional Studies 40:6, 679-689. [Crossref]

514. W. B. F. Brouwer, N. J. A. Exel, B. Gorp, W. K. Redekop. 2006. The CarerQol instrument: A new instrument to measure care-related quality of life of informal caregivers for use in economic evaluations. Quality of Life Research 15:6, 1005-1021. [Crossref]

515. Gero Carletto, Alberto Zezza. 2006. Being poor, feeling poorer: Combining objective and subjective measures of welfare in Albania. The Journal of Development Studies 42:5, 739-760. [Crossref]

516. S UPPAL. 2006. Impact of the timing, type and severity of disability on the subjective well-being of individuals with disabilities. Social Science \& Medicine 63:2, 525-539. [Crossref]

517. John Hobcraft. 2006. The ABC of demographic behaviour: How the interplays of alleles, brains, and contexts over the life course should shape research aimed at understanding population processes. Population Studies 60:2, 153-187. [Crossref]

518. Heinz Welsch. 2006. Environment and happiness: Valuation of air pollution using life satisfaction data. Ecological Economics 58:4, 801-813. [Crossref]

519. Pamela Abbott, Roger Sapsford. 2006. Life-Satisfaction in Post-Soviet Russia and Ukraine. Journal of Happiness Studies 7:2, 251-287. [Crossref]

520. Esperanza Vera-Toscano, Victoria Ateca-Amestoy, Rafael Serrano-Del-Rosal. 2006. Building Financial Satisfaction. Social Indicators Research 77:2, 211-243. [Crossref]

521. Luigino Bruni, Luca Stanca. 2006. Income Aspirations, Television and Happiness: Evidence from the World Values Survey. Kyklos 59:2, 209-225. [Crossref]

522. Andrew Eggers, Clifford Gaddy, Carol Graham. 2006. Well-being and unemployment in Russia in the 1990s: Can society's suffering be individuals' solace?. The Journal of Socio-Economics 35:2, 209-242. [Crossref]

523. Mathias Binswanger. 2006. Why does income growth fail to make us happier?. The Journal of SocioEconomics 35:2, 366-381. [Crossref]

524. Orsolya Lelkes. 2006. Knowing what is good for you. The Journal of Socio-Economics 35:2, 285-307. [Crossref]

525. YEW-KWANG NG. 2006. SOME POLICY IMPLICATIONS OF BEHAVIORAL ECONOMICS AND HAPPINESS STUDIES FOR SINGAPORE: WITH SPECIAL REFERENCE TO CASINOS. The Singapore Economic Review 51:01, 1-18. [Crossref]

526. Alois Stutzer, Bruno S. Frey. 2006. Does marriage make people happy, or do happy people get married?. The Journal of Socio-Economics 35:2, 326-347. [Crossref]

527. Lonnie Golden, Barbara Wiens-Tuers. 2006. To your happiness? Extra hours of labor supply and worker well-being. The Journal of Socio-Economics 35:2, 382-397. [Crossref]

528. Tomi Ovaska, Ryo Takashima. 2006. Economic policy and the level of self-perceived well-being: An international comparison. The Journal of Socio-Economics 35:2, 308-325. [Crossref]

529. John M. Gowdy. 2006. Evolutionary Theory and Economic Policy with Reference to Sustainability. Journal of Bioeconomics 8:1, 1-19. [Crossref] 
530. Rafael Di Tella, Robert MacCulloch. 2006. Some Uses of Happiness Data in Economics. Journal of Economic Perspectives 20:1, 25-46. [Abstract] [View PDF article] [PDF with links]

531. John Hudson. 2006. Institutional Trust and Subjective Well-Being across the EU. Kyklos 59:1, 43-62. [Crossref]

532. Mark S. Dorfman, Steven C. Tippins. 2006. An Examination of Alternative Approaches to Risk Management and Insurance Research. Risk Management <btml_ent glyph="@amp;" ascii="ひ"/> Insurance Review 9:1, 63. [Crossref]

533. Mireille Razafindrakoto, François Roubaud. 2006. Les déterminants du bien-être individuel en Afrique francophone : le poids des institutions. Afrique contemporaine 220:4, 191. [Crossref]

534. Claudia Senik. 2006. Ambition et jalousie. La perception du revenu d'autrui dans la « vieille Europe », la «nouvelle Europe » et les États-Unis. Revue économique 57:3, 645. [Crossref]

535. Lars P. Feld, Simon Hug. 2005. Economic Models in Politics: An Introduction. Swiss Political Science Review 11:4, 1-17. [Crossref]

536. Frederick J. Zimmerman, Wayne Katon. 2005. Socioeconomic status, depression disparities, and financial strain: what lies behind the income-depression relationship?. Health Economics 14:12, 1197-1215. [Crossref]

537. ALFRED MICHAEL DOCKERY. 2005. The Happiness of Young Australians: Empirical Evidence on the Role of Labour Market Experience. Economic Record 81:255, 322-335. [Crossref]

538. Robert Nuscheler, Thomas Knaus. 2005. Risk selection in the German public health insurance system. Health Economics 14:12, 1253-1271. [Crossref]

539. Basant K. Kapur. 2005. Can faster income growth reduce well-being?. Social Choice and Welfare 25:1, 155-171. [Crossref]

540. Rafael Muñoz de Bustillo Llorente, Enrique Fernández Macías. 2005. Job satisfaction as an indicator of the quality of work. The Journal of Socio-Economics 34:5, 656-673. [Crossref]

541. Rajen Mookerjee, Krista Beron. 2005. Gender, religion and happiness. The Journal of Socio-Economics 34:5, 674-685. [Crossref]

542. Francis Green, Nicholas Tsitsianis. 2005. An Investigation of National Trends in Job Satisfaction in Britain and Germany. British Journal of Industrial Relations 43:3, 401-429. [Crossref]

543. Daniel Kahneman, Robert Sugden. 2005. Experienced Utility as a Standard of Policy Evaluation. Environmental and Resource Economics 32:1, 161-181. [Crossref]

544. Yew-Kwang Ng. 2005. Policy Implications of Behavioural Economics: With Special Reference to the Optimal Level of Public Spending. The Australian Economic Review 38:3, 298-306. [Crossref]

545. Hans-Peter Kohler, Jere R. Behrman, Axel Skytthe. 2005. Partner + Children = Happiness? The Effects of Partnerships and Fertility on Well-Being. Population and Development Review 31:3, 407-445. [Crossref]

546. Nava Ashraf, Colin F. Camerer, George Loewenstein. 2005. Adam Smith, Behavioral Economist. Journal of Economic Perspectives 19:3, 131-145. [Abstract] [View PDF article] [PDF with links]

547. Erzo F. P. Luttmer. 2005. Neighbors as Negatives: Relative Earnings and Well-Being*. Quarterly Journal of Economics 120:3, 963-1002. [Crossref] 
548. Michael A. Shields, Stephen Wheatley Price. 2005. Exploring the economic and social determinants of psychological well-being and perceived social support in England. Journal of the Royal Statistical Society: Series A (Statistics in Society) 168:3, 513-537. [Crossref]

549. Helge Peukert. 2005. The Clarence Ayres Memorial Lecture: The Paradoxes of Happiness in an Old Institutionalist Perspective. Journal of Economic Issues 39:2, 335-345. [Crossref]

550. Bruno Frey, Alois Stutzer. 2005. Happiness Research: State and Prospects. Review of Social Economy 63:2, 207-228. [Crossref]

551. Miriam Teschl, Flavio Comim. 2005. Adaptive Preferences and Capabilities: Some Preliminary Conceptual Explorations. Review of Social Economy 63:2, 229-247. [Crossref]

552. 2005. Promoting happiness, respecting difference? New perspectives on the politics and sociology of education in liberal democracy. British Educational Research Journal 31:3, 391-403. [Crossref]

553. Ross Gittins. 2005. An Economics Fit for Humans. The Australian Economic Review 38:2, 121-127. [Crossref]

554. Des Gasper. 2005. Subjective and Objective Well-Being in Relation to Economic Inputs: Puzzles and Responses. Review of Social Economy 63:2, 177-206. [Crossref]

555. Matthias Benz. 2005. Not for the Profit, but for the Satisfaction? - Evidence on Worker Well-Being in Non-Profit Firms. Kyklos 58:2, 155-176. [Crossref]

556. Rafael Di Tella, Robert MacCulloch. 2005. Partisan Social Happiness. Review of Economic Studies 72:2, 367-393. [Crossref]

557. David E. Kaun. 2005. Income and happiness: earning and spending as sources of discontent. The Journal of Socio-Economics 34:2, 161-177. [Crossref]

558. Andrew Clark, Fabrice Etile, Fabien Postel-Vinay, Claudia Senik, Karine Van der Straeten. 2005. Heterogeneity in Reported Well-Being: Evidence from Twelve European Countries*. The Economic Journal 115:502, C118-C132. [Crossref]

559. Arjan M. Lejour, Ruud A. Mooij. 2005. Turkish Delight: Does Turkey's Accession to the EU Bring Economic Benefits?. Kyklos 58:1, 87-120. [Crossref]

560. Claudia Senik. 2005. Income distribution and well-being: what can we learn from subjective data?. Journal of Economic Surveys 19:1, 43-63. [Crossref]

561. Juliet B. Schor. 2005. Sustainable Consumption and Worktime Reduction. Journal of Industrial Ecology 9:1-2, 37-50. [Crossref]

562. Fumio Ohtake, Jun Tomioka. 2004. WHO SUPPORTS REDISTRIBUTION?*. The Japanese Economic Review 55:4, 333-354. [Crossref]

563. BRUCE HEADEY, MARK WOODEN. 2004. The Effects of Wealth and Income on Subjective Well-Being and Ill-Being*. Economic Record 80:s1, S24-S33. [Crossref]

564. E. Diener, M. E.P. Seligman. 2004. Beyond Money: Toward an Economy of Well-Being. Psychological Science in the Public Interest 5:1,1-31. [Crossref]

565. Alois Stutzer, Rafael Lalive. 2004. The Role of Social Work Norms in Job Searching and Subjective Well-Being. Journal of the European Economic Association 2:4, 696-719. [Crossref]

566. Kenneth Greene, Bong Joon Yoon. 2004. Religiosity, Economics and Life Satisfaction. Review of Social Economy 62:2, 245-261. [Crossref] 
567. E Bardasi. 2004. The impact of atypical employment on individual wellbeing: evidence from a panel of British workers. Social Science \& Medicine 58:9, 1671-1688. [Crossref]

568. Daniel Kahneman, Alan B. Krueger, David Schkade, Norbert Schwarz, Arthur Stone. 2004. Toward National Well-Being Accounts. American Economic Review 94:2, 429-434. [Citation] [View PDF article] [PDF with links]

569. J Komlos. 2004. From the tallest to (one of) the fattest: the enigmatic fate of the American population in the 20th century. Economics \& Human Biology 2:1, 57-74. [Crossref]

570. Larry Samuelson. 2004. Information-Based Relative Consumption Effects. Econometrica 72:1, 93-118. [Crossref]

571. Christopher K. Hsee, Jiao Zhang. 2004. Distinction Bias: Misprediction and Mischoice Due to Joint Evaluation. Journal of Personality and Social Psychology 86:5, 680-695. [Crossref]

572. . References . [Crossref]

573. R. A. Easterlin. 2003. Explaining happiness. Proceedings of the National Academy of Sciences 100:19, 11176-11183. [Crossref]

574. Rainald Borck. 2003. Führt fiskalische Äquivalenz zu einer effizienten Allokation? Die Rolle von Mehrheitsabstimmungen. Vierteljabrshefte zur Wirtschaftsforschung 72:3, 444-457. [Crossref]

575. Daniel Kahneman. 2003. A Psychological Perspective on Economics. American Economic Review 93:2, 162-168. [Citation] [View PDF article] [PDF with links]

576. Justin Wolfers. 2003. Is Business Cycle Volatility Costly? Evidence from Surveys of Subjective WellBeing. International Finance 6:1,1-26. [Crossref] 